\title{
ipen
}

INSTITUTO DE PESQUISAS ENERGÉTICAS E NUCLEARES

Autarquia associada à Universidade de São Paulo

\section{DESENVOLVIMENTO DE MEMBRANAS ANIÔNICAS OBTIDAS POR ENXERTIA VIA IRRADIAÇÃO PARA APLICAÇÃO EM CÉLULAS A COMBUSTÍVEL ALCALINAS}

\author{
Clotilde Coppini Pereira
}

\begin{abstract}
Dissertação apresentada como parte dos requisitos para obtenção do Grau de Mestre em Ciências na Área de Tecnologia Nuclear - Materiais.
\end{abstract}

Orientadora:

Dra. Elisabete Inácio Santiago

Coorientador:

Dr. Leonardo G. de Andrade e Silva

São Paulo 
INSTITUTO DE PESQUISAS ENERGÉTICAS E NUCLEARES

Autarquia associada à Universidade de São Paulo

\section{DESENVOLVIMENTO DE MEMBRANAS ANIÔNICAS \\ OBTIDAS POR ENXERTIA VIA IRRADIAÇÃO \\ PARA APLICAÇÃO EM CÉLULAS}

A COMBUSTÍVEL ALCALINAS

Clotilde Coppini Pereira

Dissertação apresentada como
parte dos requisitos para
obtenção do Grau de Mestre em
Ciências na Área de Tecnologia
Nuclear - Materiais.

Orientadora:

Dra. Elisabete Inácio Santiago

Coorientador:

Dr. Leonardo G. de Andrade e Silva

São Paulo 
Ao meu pai João (in memorian) e minha mãe Cleonice por me ensinarem, a partir de seus exemplos, a importância de se ter um sonho, assim como a valorizar o estudo. Com amor e dedicação apoiaram e incentivaram meu interesse na busca pelo saber.

Às minhas irmãs amadas Taís e Selma que fizeram parte desta conquista. A todos os leitores interessados no tema deste trabalho,que possam encontrar contribuições para seu próprio conhecimento. 


\section{AGRADECIMENTOS}

Agradeço a Deus pela possibilidade de mais esta realização.

Ao Instituto de Pesquisas Energéticas e Nucleares - IPEN-CNEN/SP e à Comissão Nacional de Desenvolvimento Científico e Tecnológico (CNPq), pelo apoio financeiro para a execução da pesquisa.

À orientadora Dra. Elisabete Inácio Santiago, do Centro de Células a Combustível $(\mathrm{CCCH})$ do IPEN-CNEN/SP, pela oportunidade de aprendizagem, orientação.

Ao coorientador Dr. Leonardo Gondim de Andrade e Silva, do Centro de Tecnologia das Radiações (CTR) do IPEN-CNEN/SP, pela orientação, dedicação.

Ao Dr. Orlando Rodrigues Jr., do Laboratório de Dosimetria de Doses Altas LDA, da Gerência de Metrologia das Radiações do IPEN-CNEN/SP, pela contribuição na publicação de artigos, análises e interpretação das medidas de EPR.

Ao Dr. Silas Cardoso Silva, do Laboratório de Dosimetria de Doses Altas - LDA do IPEN-CNEN/SP, pela contribuição nas análises e interpretação das medidas de EPR.

À Dra. Yasko Kodama, do Centro de Tecnologia das Radiações (CTR) do IPEN-CNEN/SP, pela contribuição na publicação de artigos, discussão e análise de resultados.

À Maria Cecília Salvadori, do Instituto de Física da USP, pela contribuição na publicação de artigos, análise e interpretação das imagens de AFM - QNM.

À Eng. Elizabeth S. R. Somessari e ao Eng. Carlos G. da Silveira, do Centro de Tecnologia das Radiações (CTR) do IPEN-CNEN/SP, pela realização da irradiação das amostras no irradiador de ${ }^{60} \mathrm{Co}$ Gammacell 220 e acelerador de elétrons JOB 188. 
Ao Dr. Pablo A. Vasques Salvador e ao MSc. Paulo Santos, do Centro de Tecnologia das Radiações (CTR) do IPEN-CNEN/SP, pela realização da irradiação das amostras no irradiador Multipropósito de ${ }^{60} \mathrm{Co}$.

Ao Dr. Ademar Benévolo Lugão, do Centro de Química e Meio Ambiente (CQMA) do IPEN-CNEN/SP, pela contribuição no planejamento do projeto, disponibilização do laboratório, reagentes e equipamentos para a realização de diversas etapas desta pesquisa.

À Dra. Monica Beatriz Mathor, do Centro de Tecnologia das Radiações (CTR) do IPEN-CNEN/SP, pela disponibilização de equipamentos para a realização de testes de estabilidade a baixas temperaturas e análises de espectroscopia Raman.

Ao Dr. Bruno Ribeiro de Matos e Jaqueline de Souza e Silva pela contribuição nas medidas de impedância e discussão dos resultados.

Ao Dr. Nelson Minoru Omi, do Centro de Tecnologia das Radiações (CTR) do IPEN-CNEN/SP, pela contribuição na área de informática.

À Sra. Elide Mastanha, professora de Inglês do IPEN-CNEN/SP, pelos ensinamentos, contribuição na publicação de artigos, dedicação e amizade.

À Dra. Heloisa Augusto Zen e ao Dr. Giovanni Galahadgio, do Centro de Química e Meio Ambiente (CQMA) do IPEN-CNEN/SP, pela contribuição no desenvolvimento do projeto e disponibilização de reagentes e equipamentos. .

Ao Sr. Eliosmar Gasparim, do Centro de Química e Meio Ambiente (CQMA) do IPEN-CNEN/SP, pela realização das análises de TG.

À Ana Claúdia Martinelli Feher, Ana Paula Moreli Bertoni e Bianca Gonçalves Montes, da Secretaria de Pós-Graduação do IPEN-CNEN/SP, pela colaboração.

Ao Marco Antônio Oliveira da Silva e Pedro Ferreira da Silva Filho, da Biblioteca do Centro de Ensino e Informação (CEI) do IPEN-CNEN/SP, pela colaboração. 
Aos amigos do Centro de Células a Combustível (CCCH) do IPEN-CNEN/SP, do Centro de Tecnologia das Radiações (CTR) do IPEN-CNEN/SP e do Centro de Ciência e Tecnologia dos Materiais (CCTM) do IPEN-CNEN/SP.

À amiga Juliana Winkel, pela contribuição e dedicação na revisão desta dissertação.

Às amigas da Oficina de Sonhos por realizar este sonho comigo.

Aos amigos Viviane S. Pereira, Natália K. Monteiro, Vinícius Andrea, Paulo Sérgio Martins da Silva $(\mathrm{CCCH})$ do Centro de Células a Combustível IPENCNEN/SP pela amizade e colaboração a este trabalho.

Aos membros da banca examinadora: Dra. Leila Figueiredo de Miranda e Dr. Antônio Munhoz Júnior da Universidade Presbiteriana Mackenzie, pelos comentários e contribuições a este trabalho 
“Quando penso em um 'significado' para a vida, me pergunto: 'será que aprendi algo hoje que me deixou mais perto de saber tudo que há para se saber?'. Se eu não sei mais do que sabia no dia anterior, para mim foi um dia desperdiçado. Então, essa não é uma questão eterna e sem resposta: ela está ao alcance das minhas mãos todos os dias." 


\title{
DESENVOLVIMENTO DE MEMBRANAS ANIÔNICAS OBTIDAS POR \\ ENXERTIA VIA IRRADIAÇÃO PARA APLICAÇÃO EM CÉLULAS A \\ COMBUSTÍVEL ALCALINAS
}

\section{CLOTILDE COPPINI PEREIRA}

\begin{abstract}
RESUMO
As membranas de troca aniônica são uma alternativa promissora para 0 desenvolvimento de eletrólitos mais eficientes para células a combustível alcalinas. Em geral, as membranas de troca aniônica são ionômeros capazes de conduzir íons hidroxila devido aos grupos quaternário de amônio e têm como característica elevado $\mathrm{pH}$ equivalente. Com o objetivo de desenvolver membranas aniônicas química e termicamente estáveis, com satisfatória condutividade iônica para aplicação em células a combustível alcalinas, as membranas aniônicas foram sintetizadas a partir de polímeros base de polietileno de baixa densidade (LDPE), polietileno de ultra alto peso molecular (PEUHMW), poli(etileno-co-tetrafluoroetileno) (PETFE) e poli(tetrafluoroetillenoco-hexafluoroetileno) (PFEP) previamente irradiados nas fontes de radiação gama de ${ }^{60} \mathrm{Co}$ ou com feixe de elétrons, para enxertia do monômero de estireno e funcionalizados com trimetilamina para incorporação dos grupos quaternário de amônio. As membranas resultantes foram caracterizadas por espectroscopia de ressonância paramagnética eletrônica (EPR), espectroscopia Raman, termogravimetria (TG), espectroscopia de impedância eletroquímica (EIS), além da determinação do grau de enxertia, capacidade de absorção de água por gravimetria e capacidade de troca iônica, por titulação. As membranas sintetizadas com os polímeros LDPE e UHMWPE préirradiados a 70 kGy com feixe de elétrons e armazenadas a baixa temperatura $\left(-70^{\circ} \mathrm{C}\right)$ por até 10 meses, mostraram resultados de condutividade iônica, quando na forma $\left(\mathrm{OH}^{-}\right)$, de $29 \mathrm{mS} . \mathrm{cm}^{-1}$ e $14 \mathrm{mS} . \mathrm{cm}^{-1}$ a $65^{\circ} \mathrm{C}$, respectivamente. Os filmes de PFEP irradiados no processo simultâneo mostram níveis de enxertia insuficientes para a síntese de membranas aniônicas, necessitando
\end{abstract}


maiores estudos para aperfeiçoar os processos de irradiação e enxertia. As membranas baseadas em PETFE, pré-irradiadas a 70 kGy com feixe de elétrons e armazenadas a baixa temperatura $\left(-70^{\circ} \mathrm{C}\right)$ por até 10 meses, mostraram maior condutividade iônica, quando na forma hidroxila $\left(\mathrm{OH}^{-}\right)$, com valores de condutividade iônica entre $90 \mathrm{mS} . \mathrm{cm}^{-1}$ e $165 \mathrm{mS} . \mathrm{cm}^{-1}$ na faixa de temperatura entre 30 e $60 \stackrel{\circ}{\circ}$. Estes resultados mostraram que membranas de LDPE, UHMWPE e PETFE são eletrólitos promissores para a aplicação em células a combustível alcalinas. 


\title{
DEVELOPMENT OF ANIONIC MEMBRANES PRODUCED BY RADIATION- GRAFTING FOR ALKALINE FUEL CELL APPLICATIONS
}

\section{CLOTILDE COPPINI PEREIRA}

\begin{abstract}
Anion Exchange Membranes (AEMs) are a promising alternative to the development of more efficient electrolytes for alkaline fuel cells. In general, the AEMs are ionomeric membranes able to conduct hydroxide ions $\left(\mathrm{OH}^{-}\right)$due to the quatermary ammonium groups, which confer high $\mathrm{pH}$ equivalent to the AEM. In order to develop alkaline membranes with high chemical and thermal stability, besides satisfactory ionic conductivity for alkaline fuel cells, membranes based on low density polyethylene (LDPE), ultrahigh weight molecular weight polyethylene (UHWHPE), poly(ethylene-cotetrafluoroethylene) (PETFE) and poly(hexafluoropropylene-cotetrafluoroethylene) (PFEP) previously irradiated by using ${ }^{60} \mathrm{Co}$ gamma and electron beam sources, have been synthesized by styrene-grafting, and functionalized with trimethylamine to introduced quaternary ammonium groups. The resulting membranes were characterized by electron paramagnetic resonance (EPR), Raman spectroscopy, thermogravimetry (TG) and electrochemical impedance spectroscopy (EIS). The determination of the grafting degree and water uptake were conducted by gravimetry and ion exchange capacity, by titration. The membranes synthesized with PELD and PEUHMW polymers pre-irradiated at $70 \mathrm{kGy}$ and stored at low temperature $(-70 \stackrel{\circ}{\circ})$, up to 10 months, showed ionic conductivity results, in hydroxide form $\left(\mathrm{OH}^{-}\right)$, of $29 \mathrm{mS} . \mathrm{cm}^{-1}$ and $14 \mathrm{mS} . \mathrm{cm}^{-1}$ at $65{ }^{\circ} \mathrm{C}$, respectively. The PFEP polymers irradiated by the simultaneous process showed insufficient grating levels for the membrane synthesis, requiring more studies to improve the irradiation and grafting process. The styrene-grafted PETFE membranes, preirradiated at $70 \mathrm{kGy}$ and stored at low temperature $\left(-70^{\circ} \mathrm{C}\right)$, up to 10 months, showed ionic conductivity results, in hydroxide form $\left(\mathrm{OH}^{-}\right)$, of $90 \mathrm{mS} . \mathrm{cm}^{-1}$ to 165 $\mathrm{mS} . \mathrm{cm}^{-1}$, in the temperature range 30 to $60^{\circ} \mathrm{C}$. Such results have demonstrated that LDPE, UHMWPE and PETFE based AEMs are promising electrolytes for alkaline fuel cell application.
\end{abstract}




\section{SUMÁRIO}

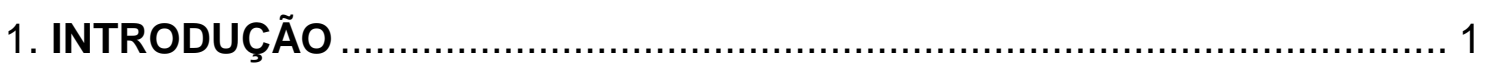

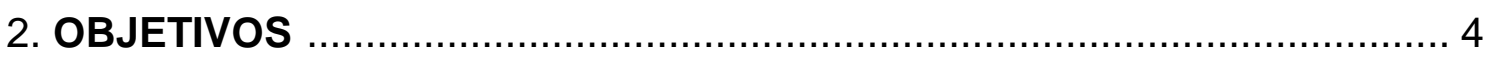

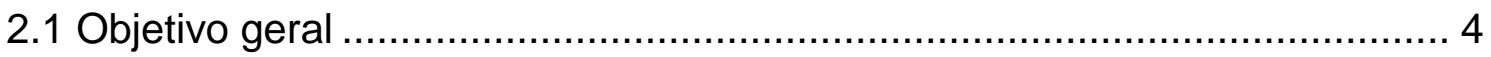

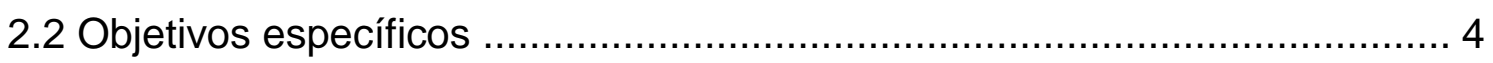

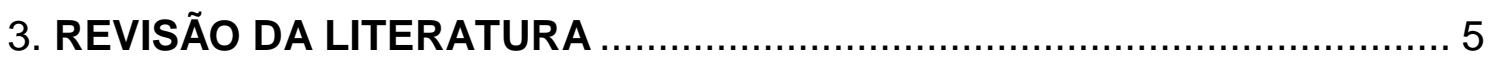

3.1 Estabilidades química, térmica e mecânica.............................................. 20

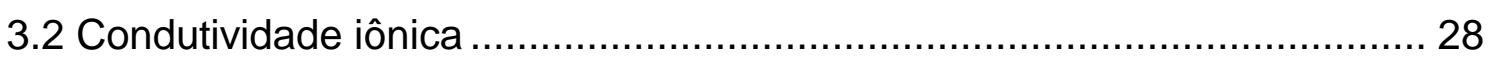

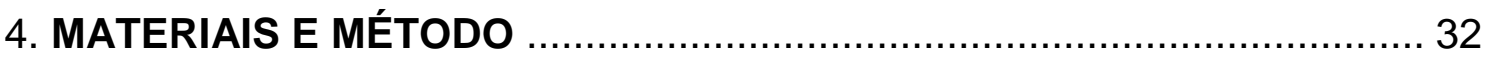

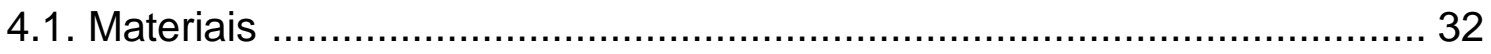

4.2 Síntese das membranas aniônicas ............................................... 33

4.2.1 Irradiação e enxertia dos polímeros .................................................. 35

4.2.1.1 Irradiador de ${ }^{60}$ Co tipo Gammacell modelo 220 .............................. 36

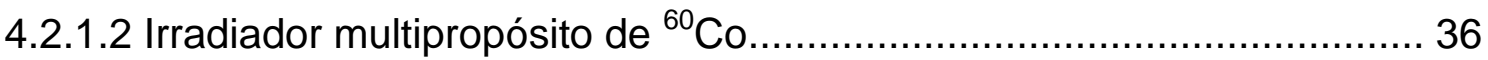

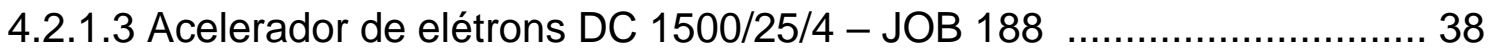

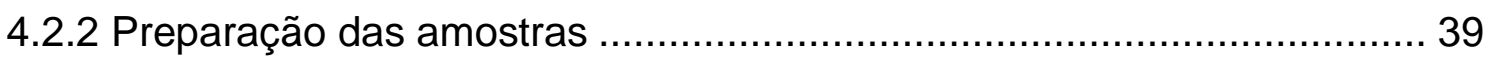

4.2.3 Reação de sulfonação dos polímeros enxertados................................ 40

4.2.4 Reação de quaternização ...................................................... 41

4.2.5 Reação de alquilação .......................................................... 42

4.3 Caracterização das membranas aniônicas.......................................... 42

4.3.1 Determinação do grau de enxertia (DOG) ..................................... 42

4.3.2 Determinação da capacidade de troca iônica das membranas

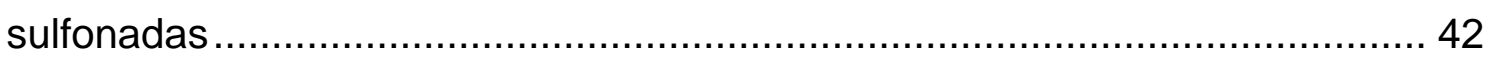

4.3.3. Determinação da capacidade de absorção de água ........................... 43

4.3.4 Determinação da capacidade de troca iônica...................................... 44

4.3.5 Espectroscopia de ressonância paramagnética eletrônica (EPR) ........... 44

4.3.6 Espectroscopia Raman .................................................... 46

4.3.7 Microscopia de varredura (MEV) ................................................... 47

4.3.8 Microscopia de força atômica usando modo de operação força Máxima QNM .................................................................................................. 47 


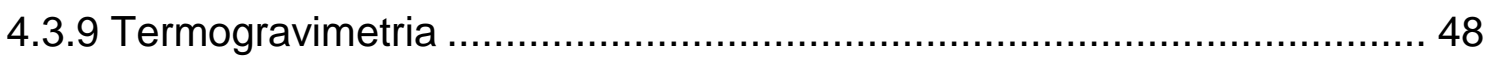

4.3.10 Espectroscopia de impedância eletroquímica (EIS) .............................. 48

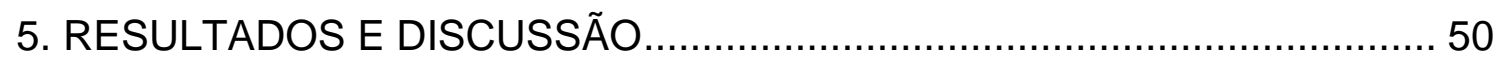

5.1 Polietileno de Baixa Densidade (LDPE) e Polietileno de Ultra Alto Peso

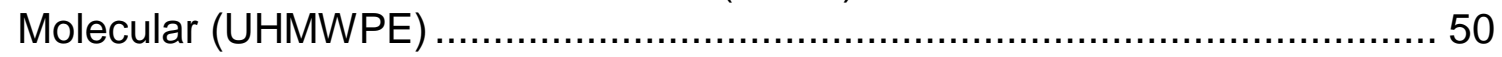

5.1.1 Identificação e decaimento dos radicais (EPR) ..................................... 50

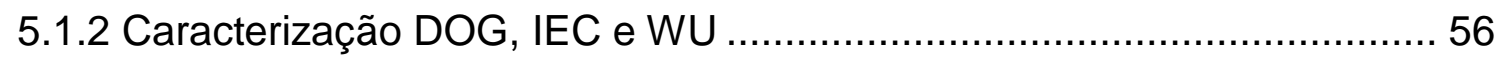

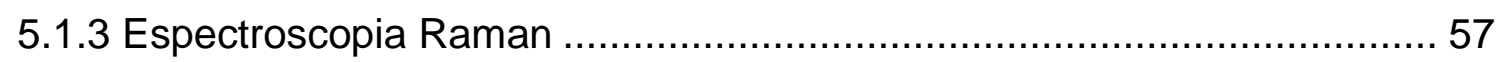

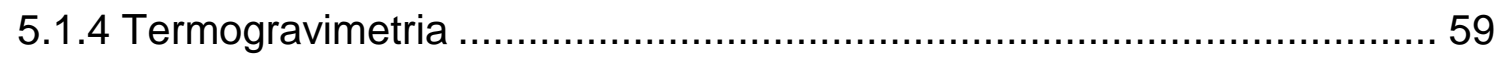

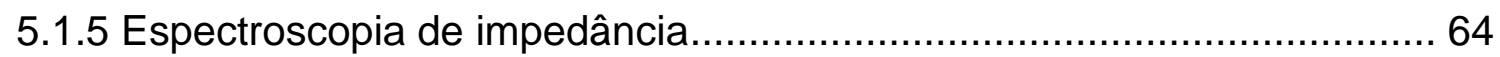

5.2. Poli(etileno-co-tetrafluoroetileno) (PETFE) ............................................ 67

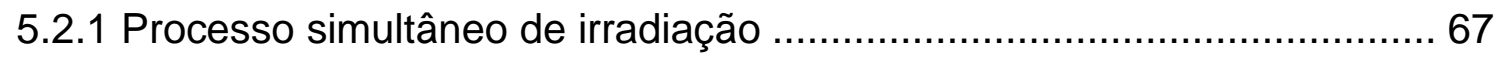

5.2.2 Processo de pré- irradiação ............................................................. 71

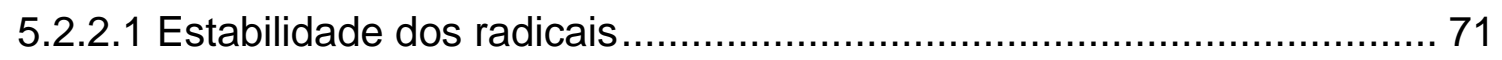

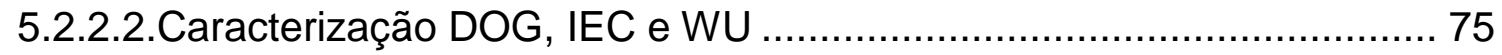

5.2.2.3 Microscopia de varredura (MEV) ................................................. 76

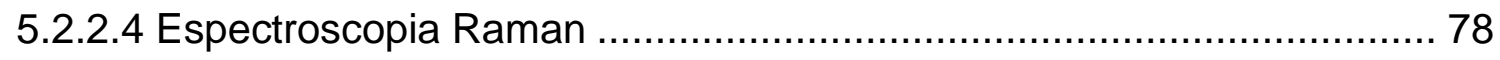

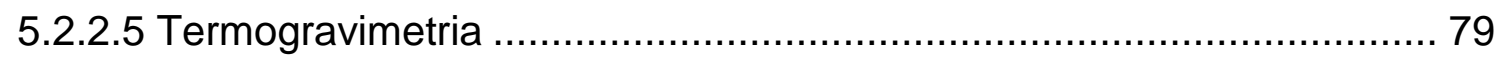

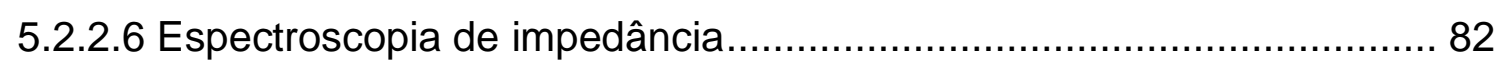

5.2.2.7 Otimização do processo …………….......................................... 85

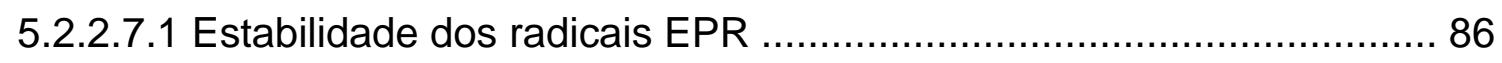

5.2.2.7.2 Caracterização DOG, IEC e WU ……………............................. 87

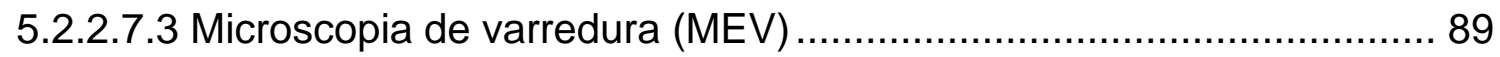

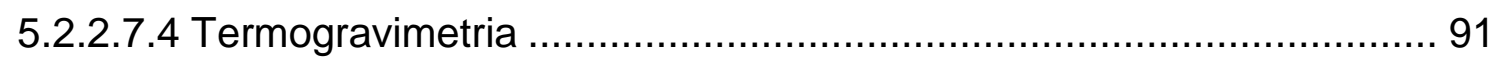

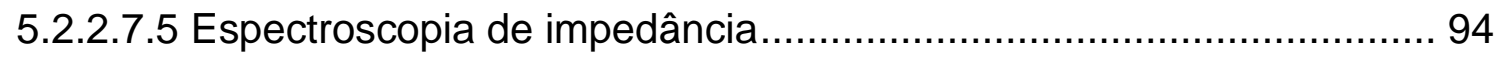

5.3. Poli (tetrafluoroetileno-co-hexafluoropropileno) (PFEP) ………............... 96

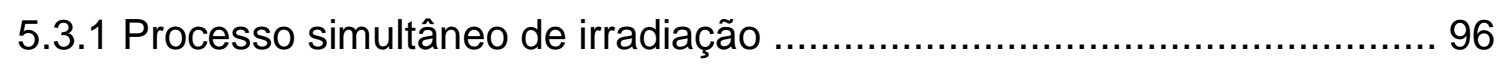

5.3.1.1 Microscopia de força atômica usando modo de força máxima

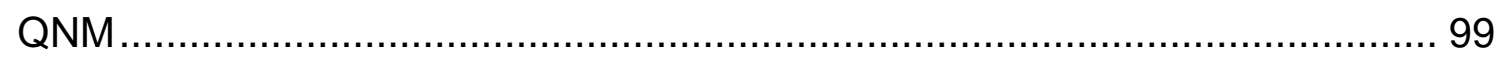

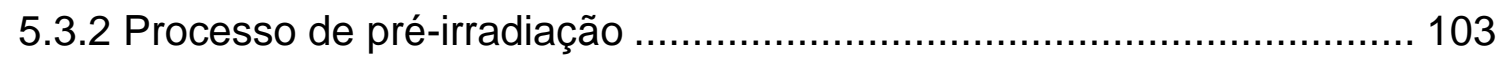


5.3.2.1 Estabilidade dos radicais ..................................................... 103

5.3.2.2 Grau de enxertia (DOG) ................................................... 105

5.3.2.3 Espectroscopia Raman ..................................................... 106

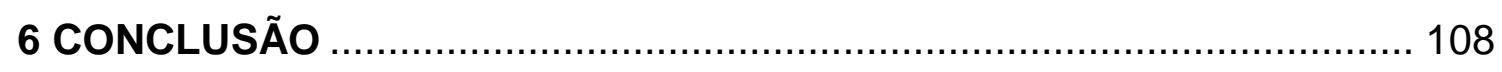

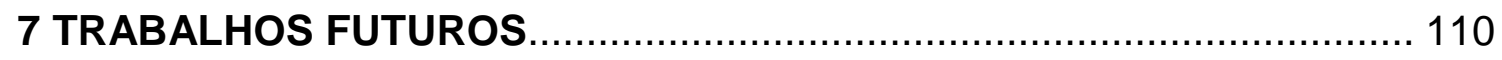

REFERÊNCIAS BIBLIOGRÁFICAS .................................................. 111 


\section{LISTA DE ABREVIATURAS}

AEM - Membrana de troca aniônica (do inglês, Anion Exchange Membrane)

AEMFC - Célula a combustível de troca aniônica (do inglês, Anion Exchange Membrane Fuel Cell)

AFC - Célula a combustível alcalina (do inglês, Alcaline Fuel Cell)

AFM - Microscopia de força atômica (do inglês, Atomic Force Microscopy)

AIEA - Agência internacional de energia atômica

CNEN - Comissão Nacional de Energia Nuclear

CNPq - Conselho Nacional de Desenvolvimento Científico e Tecnológico

${ }^{60} \mathrm{Co}$ - Cobalto - 60

DABCO - 1,4 diazobiciclo 2,2,2 octano

DBN - 1,5 diazobiciclo 4.,3,0 noneno-5

DMFC - Célula a combustível de metanol direto

DOG - Grau de enxertia

DTG - Derivada primeira da curva de TG $\left(\mathrm{mg} \mathrm{min}^{-1}\right)$

Ea - Energia de ativação

EB - Feixe de elétrons (do inglês, Electron Beam)

EIS - Espectroscopia de Impedância Eletroquímica

EPR - Espectroscopia de ressonância paramagnética eletrônica (do inglês, Electron Paramagnetic Resonance)

IEC - Capacidade de troca iônica

IEM - Membranas de troca iônica (do inglês, lon Exchange Membrane)

IPEN - Instituto de Pesquisas Energéticas e Nucleares 
LDPE - Polietileno de baixa densidade

LET - Transferência de energia linear (do inglês, linear energy transfer)

MCFC - Célula a combustível de carbonatos fundidos

MEA - Conjunto eletrodos/membana (do inglês, Membrane Electrode Assembly)

MEV - Microscopia eletrônica de varredura

PAFC - Célula a combustível de ácido fosfórico (do inglês, Phosphoric Acid Fuel Cell)

PCTFE - Poli(clorotrifluoroetileno)

PE - Polietileno

PEM - Célula a combustível protônica (do inglês, Proton Exchange Membrane)

PEMFC - Célula a combustível de troca protônica (do inglês, Proton Exchange Membrane Fuel Cell)

PES - Poli(éter-sulfona)

PETFE - Poli(etileno-co-tetrafluoroetileno)

PFA - Poli(tetrafluoroetileno-co-perfluoropropil vinil éter)

PFEP - Poli(tetrafluoroetileno-co-hexafluoroetileno)

PMMA - Poli(metacrilato de metila)

PPESK - Poli(ftalazina-éter-sulfona-cetona)

PP - Polipropileno

PPO - Poli(óxido de fenileno)

PTFE - Politetrafluoroetileno

PVC - Policloreto de vinila

PVDF - Poli(fluoreto de vinilideno) 
PVDF-co-HPF - Poli(fluoreto de vinilideno-co-hexafluoropropileno)

PVF - Poli(fluoreto de vinila)

QNM - Mapeamento nanomecânico quantitativo

$\mathrm{RH}$ - Umidade relativa do ar

SOFC - Célula a combustível de óxido sólido

TFE - Monômero de tetrafluoroetileno

TG - Termogravimetria

TMA - Trimetilamina

UHMWPE - Polietileno de ultra alto peso molecular

UV - Ultravioleta

VBC - 1,4 cloro vinilbenzeno

WU - Capacidade de absorção de água 


\section{LISTA DE FIGURAS}

FIGURA 1 - Estruturas químicas das membranas perfluoradas: (A) Nafion ${ }^{\text {TM }}$ e

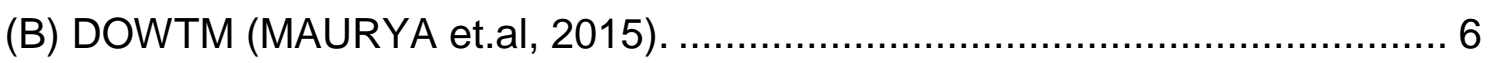

FIGURA 2 - Esquema simplificado de uma célula a combustível alcalina de membrana de troca aniônica, as reações e a direção do transporte dos íons e elétrons. Adaptada de (MAURYA et al., 2015).

FIGURA 3 - Esquema simplificado de um MEA (conjunto eletrodos/membrana) de uma célula do tipo PEFC (célula a combustível de eletrólito polimérico) (GUBLER, 2014).

FIGURA 4 - Esquema dos eventos envolvidos na radiação ionizante Induzida. Adaptada de (BRADLEY, 1984).

FIGURA 5 - Resumo das reações de enxertia utilizando o processo de préirradiação: formação de sítios ativos durante exposição à irradiação; formação dos radicais (hidro)peróxidos no caso de reação na presença de ar, e iniciação da reação de copolimerização de enxerto (GUBLER, 2014).

FIGURA 6 - Mecanismo de degradação da reação entre $\mathrm{OH}$ - e grupos trocadores de ânions (grupos catiônicos) baseados em benziltrimetilamônio. (VARCOE et al., 2014)

FIGURA 7 - Mecanismo Groutthuss para o transporte dos íons hidroxila $(\mathrm{OH}-)$ em água (MAURYA et al.., 2015). 29

FIGURA 8 - Processo de preparação das membranas aniônicas (AEMs) ...... 34

FIGURA 9 - Processo de síntese das membranas aniônicas de filmes de LDPE, UHMWPE, PETFE, PFEP enxertados por irradiação. Adaptada de (VARCOE e SLADE, 2006) 35

FIGURA 10 - Imagens: (A) e (B) Irradiador de ${ }^{60}$ Co GammaCell modelo 220 do CTR do IPEN - CNEN/SP; e (C) amostras dos filmes de polímeros irradiados pelo processo simultâneo. 36 
Figura 11 - Imagens: Irradiador Multipropósito de ${ }^{60} \mathrm{Co}$ do CTR/IPENCNEN/SP. (A) Esquema panorâmico do irradiador Multipropósito de ${ }^{60} \mathrm{Co}$, (B) Fontes de ${ }^{60}$ Co distribuídas nos racks no interior da piscina, (C) Vista externa do Irradiador Multipropósito de ${ }^{60} \mathrm{Co}$.

FIGURA 12 - Imagens: (A) Acelerador de elétrons JOB 188 tipo Dynamitron do CTR /IPEN-CNEN/SP, (B) amostras de filmes pré-irradiados 38

FIGURA 13 - Reação de sulfonação. Adaptada de (GUBLER, 2014) 41

FIGURA 14 - Gráfico de força em função da distância entre ponta e amostra (MEYER; HUG; BENNEWITZ,1965; BONNELL, 1993; PITTENGER, B.,2012).48

FIGURA 15 - Espectro EPR do LDPE pré-irradiado a 70 kGy após 7 dias e armazenados à baixa temperatura $\left(-70 \pm 4{ }^{\circ} \mathrm{C}\right)$, irradiados e medidos a temperatura ambiente. (u.a. - unidade arbitrária).

FIGURA 16 - Espectro EPR do UHMWPE pré-irradiado a 70 kGy após 7 dias e armazenados à baixa temperatura $(-70 \pm 4 \stackrel{\circ}{\circ})$, irradiados e medidos a temperatura ambiente.

FIGURA 17 - Espectros EPR de filmes de LDPE pré-irradiados a 70 kGy e armazenados a baixa temperatura $\left(-70 \pm 4{ }^{\circ} \mathrm{C}\right)$ durante 180 dias, irradiados e medidos a temperatura ambiente 53

FIGURA 18 - Espectros EPR de filmes de UHMWPE pré-irradiados a 70 kGy e armazenados a baixa temperatura $(-70 \pm 4 \stackrel{\circ}{\circ}$ ) durante 180 dias, irradiados e medidos a temperatura ambiente. 54

FIGURA 19 - Amplitude do sinal EPR pico-a-pico normalizado versus tempo de armazenamento a baixa temperatura $(-70 \pm 4 \stackrel{\circ}{\circ})$ dos filmes de LDPE e UHMWPE, pré-irradiados a $70 \mathrm{kGy}$ e armazenados a baixa temperatura (-70 \pm $4 \stackrel{\circ}{\circ}$ ) durante 180 dias, irradiados e medidos a temperatura ambiente. 55

FIGURA 20 - Espectro Raman do LDPE não-irradiado (LDPE), LDPE após enxertia com solução monômero de estireno: propano-2-ol (60:40 v:v) (LDPE-gEstireno), e membrana de troca aniônica na forma $\mathrm{OH}$ - (AEM). O espectro foi obtido no intervalo de $400-2000 \mathrm{~cm}^{-1}$, laser $532 \mathrm{~nm}$. 58 
FIGURA 21 - Espectro Raman do UHMWPE não-irradiado (LDPE), UHMWPE após enxertia com solução monômero de estireno:propano-2-ol (60:40 v:v) (UHMWPE-g-Estireno), e membrana de troca aniônica na forma $\mathrm{OH}$ - (AEM). O espectro foi obtido no intervalo de $400-2000 \mathrm{~cm}^{-1}$, laser $532 \mathrm{~nm}$................ 59

FIGURA 22 - Curvas TG das amostras: (a) LDPE não irradiadas, (b) préirradiada a 70 kGy e enxertadas em solução de estireno: propano-2-ol (60:40 v:v), e (c) membrana aniônica na forma $\left(\mathrm{OH}^{-}\right)$obtidas a $10^{\circ} \mathrm{C} \mathrm{min}^{-1}$ e sob atmosfera de $\mathrm{N}_{2}$.

Figura 23- Curvas DTG das amostras de LDPE: (a) não irradiada, (b) préirradiada a 70 kGy e enxertadas com estireno (solução estireno: propano-2ol),e membrana aniônica na forma $\left(\mathrm{OH}^{-}\right)$, obtidas a $10 \stackrel{\circ}{\mathrm{C}} \mathrm{min}^{-1} \mathrm{sob}$ atmosfera de $\mathrm{N}_{2}$.

FIGURA 24 - Curvas TG das amostras: (a) UHMWPE não irradiadas, (b) UHMWPE pré-irradiada em feixe de elétrons a 70 kGy e enxertadas com estireno (solução 60:40 estireno: propano-2-ol, v:v),e (c) membrana aniônica na forma $(\mathrm{OH}-)$; obtidas com razão de aquecimento de $10 \stackrel{\circ}{\circ} \mathrm{C} \min ^{-1}$ e sob atmosfera de $\mathrm{N}_{2}$ 62

FIGURA 25 - Curvas de DTG das amostras de UHMWPE: (a) não irradiada, (b) UHMWPE pré-irradiada a 70 kGy em feixe de elétrons e enxertadas com estireno (solução estireno: propano-2-ol), e membrana aniônica na forma $\left(\mathrm{OH}^{-}\right)$, obtidas com razão de aquecimento de $10{ }^{\circ} \mathrm{C} \mathrm{min}^{-1}$ sob atmosfera de $\mathrm{N}_{2}$ 62

FIGURA 26 - Condutividade iônica das membranas aniônicas dos polímeros de LDPE e de UHMWPE hidratadas na forma (OH-). Medidas em $\mathrm{RH}=100 \%, 2$ pontas, faixa de frequência de $30 \mathrm{MHz}$ a $0,1 \mathrm{~Hz}$. 65

FIGURA 27 - Gráfico de Arrhenius das membranas dos polímeros LDPE e UHMWPE hidratadas na forma ( $\mathrm{OH}-)$. Medidas em $\mathrm{RH}=100 \%$ 66

FIGURA 28 - Variação do grau de enxertia dos filmes de PETFE irradiados nas soluções de:(a) estireno:tolueno 60:40, v:v; (b) estireno:propano-2-ol 60:40, v:v; e (c) estireno:tolueno 20:80, v:v; em função da dose absorvida de radiação... 68 
FIGURA 29 - Variação do grau de enxertia dos filmes de PETFE irradiados nas soluções de:(a) estireno:tolueno 60:40, v:v; (b) estireno:propano-2-ol 60:40, v:v; (c) estireno:tolueno 20:80, v:v; em função da dose absorvida de radiação...... 69

FIGURA 30 - Espectros EPR de filmes de PETFE pré-irradiados a 70 kGy com feixe de elétrons e mantido a temperatura ambiente durante 60 dias, irradiados e medidos a temperatura ambiente.

Figura 31 - Amplitude do sinal EPR pico-a-pico normalizado versus tempo de armazenamento a baixa temperatura $(-70 \pm 4 \stackrel{\circ}{\circ})$ em dias dos filmes de PETFE, pré-irradiados a $70 \mathrm{kGy}$ e armazenados a baixa temperatura $(-70 \pm 4$ $\left.{ }^{\circ} \mathrm{C}\right)$ durante 180 dias medidos e irradiados a temperatura ambiente 73

FIGURA 32 - Espectros EPR de filmes de PETFE pré-irradiados a $70 \mathrm{kGy}$ e mantidos a (70 $\pm 4 \stackrel{\circ}{\circ}$ ) durante 240 dias, irradiados e medidos a temperatura ambiente.

Figura 33 - Amplitude do sinal EPR pico-a-pico normalizado versus tempo de armazenamento a baixa temperatura $(-70 \pm 4 \stackrel{\circ}{\circ})$ em dias dos filmes de LDPE e UHMWPE, pré-irradiados a $70 \mathrm{kGy}$ e armazenados a baixa temperatura (-70 $\pm 4 \stackrel{\circ}{\circ}$ ) durante 180 dias, irradiados e medidos a temperatura ambiente 75

FIGURA 34 - Imagens MEV dos filmes e membranas de PETFE: Filmes de PETFE pré-irradiados a $70 \mathrm{kGy}$ ao ar e temperatura ambiente mantidos a baixa temperatura (-70 $\pm 4 \mathrm{C}$ ):(A) PETFE $2 \mathrm{~m}$ - após 2 meses, (B): PETFE $10 \mathrm{~m}$ após 10 meses. Membranas de PETFE na forma $(\mathrm{OH}-)$; (C) MEA $2 \mathrm{~m}-$ sintetizadas após 2 meses e (D)- MEA - $10 \mathrm{~m}$ - sintetizadas após 10 meses. Ampliação $3000 \mathrm{x}$ 77

FIGURA 35 - Espectro Raman do PETFE não-irradiado, PETFE após enxertia com solução monômero de estireno:propano-2-ol (60:40 v:v) (PETFE-gEstireno), e membrana de troca aniônica de PETFE na forma OH- (AEM) (após 10 meses a $-70 \pm 4 \stackrel{\circ}{\circ}$ ). $O$ espectro foi obtido no intervalo de $400-2000$ $\mathrm{cm}^{-1}$, laser $532 \mathrm{~nm}$ 78

Figura 36 - Curvas de TG (a) e (c) e DTG (b) e (d) das amostras após 2 e 10 meses (2m e 10 m): (a) PETFE não irradiadas, PETFE pré-irradiada em feixe 
de elétrons a 70 kGy e enxertadas com estireno (solução 60:40 estireno: propano-2-ol, v:v),e membrana aniônica na forma (OH-) obtidas a $10 \stackrel{\circ}{\circ} \mathrm{C} \mathrm{min}{ }^{-1} \mathrm{e}$ sob atmosfera de $\mathrm{N}_{2}$. 80

FIGURA 37 - Condutividade aniônica das membranas aniônicas hidratadas na forma $(\mathrm{OH}-)$ do polímero de PETFE sintetizadas após 2 e 10 meses de armazenamento abaixa temperatura $\left(-70 \pm 4^{\circ} \mathrm{C}\right)$ em $\mathrm{RH}=100 \%$. Medidas em $\mathrm{RH}=100 \%, 2$ pontas, faixa de frequência de $30 \mathrm{MHz}$ a $0,1 \mathrm{~Hz}$. 83

FIGURA 38 - Gráfico de Arrhenius das membranas aniônicas do polímero de PETFE hidratadas na forma (OH-) sintetizadas após 2 e 10 meses. 84

FIGURA 39 - Espectros EPR dos filmes de ETFE pré-irradiados a 70 e 100 kGy em função do tempo de armazenamento a $-70 \pm 4 \stackrel{\circ}{\circ}$ ( 0 e 270 dias $)$

Figura 40 - Imagens das amostras dos filmes e membranas de PETFE préirradiados a $70 \mathrm{kGy}$ e enxertados após irradiação e 10 meses a baixa temperatura. Filmes de PETFE pré-irradiados: $A M \# 1(A), A M \# 2(B), A M \# 3(C)$, AM\#4 (D). Membranas hidratadas na forma ( OH-: AM\#1 (E), AM\#2 (F), AM\#\# (G), AM\#4 (H) 89

Figura 41 - Imagens MEV dos filmes de PETFE pré-irradiados a $70 \mathrm{kGy}$ ao ar e a temperatura ambiente mantidos a baixa temperatura $\left(-70 \pm 4{ }^{\circ} \mathrm{C}\right)$ em função da dose de radiação e tempo de armazenamento a baixa temperatura: AM\#1, AM\#2, AM\#3 e AM\#4.(A) Ampliação 3000 x. 90

Figura 42 - Imagens MEV das membranas na forma $(\mathrm{OH}-)$ de PETFE préirradiados a $70 \mathrm{kGy}$ ao ar e a temperatura ambiente mantidos a baixa temperatura $(-70 \pm 4 \stackrel{\circ}{\circ})$ em função da dose de radiação e tempo de armazenamento a baixa temperatura: AM\#1, AM\#2, AM\#3 e AM\#4 (A) Ampliação $3000 \mathrm{x}$

Figura 43 - Curvas TG (a) e (c) e DTG (b) e (d) das amostras AM\#1, AM\#2, AM\#3, AM\#4: PETFE não irradiadas, PETFE pré-irradiada a 70 kGy e $100 \mathrm{kGy}$ e enxertadas com estireno (solução 60:40 estireno: propano-2-ol, v:v) imediatamente após a irradiação e após 10 meses de armazenamento em 
baixa temperatura (70 $\pm 4 \stackrel{\circ}{\circ})$, e membrana aniônica na forma $(\mathrm{OH}-)$ obtidas a $10 \stackrel{\circ}{\circ} \min ^{-1}$ e sob atmosfera de $\mathrm{N}_{2}$

FIGURA 44 - Condutividade aniônica das membranas aniônicas hidratadas na forma (OH-) do polímero de PETFE : AM\#1, AM\#2, AM\#3, AM\#4. Medidas em $\mathrm{RH}=100 \%, 2$ pontas, faixa de freqüência de $30 \mathrm{MHz}$ a $0,1 \mathrm{~Hz}$. 94

FIGURA 45 - Gráfico de Arrhenius das membranas aniônicas do polímero de PETFE AM\#1, AM\#2, AM\#3 e AM\#4 hidratadas na forma $(\mathrm{OH}-)$ 95

FIGURA 46 - Micrografias de força atômica, usando modo PeakForce QNM dos filmes de PFEP enxertados nas condições: (A) sem irradiar, (B) 60 kGy, 6 h, S:T 60:40, (C) 40 kGy, 4 h, S:T 60:40, (D) 60 kGy, 30 h, S:T 60:40, (E) 60 kGy,6 h, S:T 20:80, (F) 60 kGy,6 h, S:P 60:40. 101

FIGURA 47 - Micrografias de força atômica mostrando a aderência (entre ponta e superfície) e módulo elástico obtido por PeakForce QNM dos filmes de PFEP nas condições (C) 40 kGy, 4 h, S:T 60:40 v:v, (D) 60 kGy, 30 h, S:T 60:40 v:v, (F) 60 kGy, 6 h, S:P 60:40 v:v 103

FIGURA 48 - Espectros EPR dos filmes de PFEP pré-irradiados a 70 kGy e armazenados a baixa temperatura $(70 \pm 4 \stackrel{\circ}{\circ})$ durante 240 dias medidos e irradiados a temperatura ambiente. 104

FIGURA 49 - Amplitude do sinal EPR pico-a-pico normalizado versus tempo de armazenamento a baixa temperatura $\left(-70 \pm 4^{\circ} \mathrm{O}\right)$ dos filmes de PFEP, préirradiados a $70 \mathrm{kGy}$ e armazenados a baixa temperatura $(-70 \pm 4 \stackrel{\circ}{ } \mathrm{C})$ durante 240 dias medidos e irradiados a temperatura ambiente. 105

FIGURA 50 - Espectros Raman dos filmes de PFEP não irradiados, irradiados no irradiador Multipropósito de ${ }^{60} \mathrm{Co}$ (espectros sobrepostos) e no acelerador de elétrons enxertados em solução de estireno:propano 2-ol (60:40, v:v) 106 


\section{LISTA DE TABELAS}

TABELA 1 - Reações decorrentes da interação da radiação ionizante com a matéria. (BRADLEY, 1984; WOODS e PIKAEV, 1994).

TABELA 2 - Características dos processos de enxertia pelo processo de irradiação simultânea e de pré-irradiação (NASEF e HEGAZY, 2004). 19

TABELA.3 - Polímeros utilizados na síntese de membranas aniônicas utilizando o processo enxertia via irradiação (DARGAVILLE et. al., 2003;

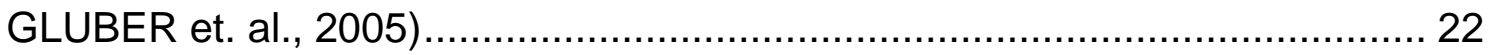

TABELA 4 - Filmes poliméricos utilizados na síntese das AEMs .................. 32

TABELA 5 - Reagentes e solventes utilizados na síntese das AEMs............. 33

TABELA 6 - Dosímetros de rotina de PMMA com corantes fabricados pela Harwell Dosimeters Ltd. 38

TABELA 7 - Resultados de DOG, IEC, WU das membranas de LDPE e de UHMWPE. 56

TABELA 8 - Resultados de DOG, IEC, WU das membranas de ETFE em função do tempo de armazenamento dos filmes a $-70 \pm 4^{\circ} \mathrm{C}$ (2 e 10 meses) . 76

TABELA 9 - Parâmetros do processo de síntese das membranas do polímero de PETFE. 86

TABELA 10 - Resultados de DOG, IEC e WU das membranas de PETFE em função da dose de radiação e tempo de armazenamento a -70 $\pm 4{ }^{\circ} \mathrm{C}$ 88

TABELA 11 - Resultados de condutividade e energia de ativação das membranas AM\#1, AM\#2, AM\#3 e AM\#4. 96

TABELA 12 Parâmetros de processo e resultado de DOG. Variação do grau de enxertia do polímero de PFEP nas soluções de estireno:tolueno 60:40, v:v; estireno:propano-2-ol 60:40, v:v; e estireno:tolueno 20:80, v:v; em função da dose de radiação. 
TABELA 13 - Resultados do grau de enxertia dos filmes de PFEP e parâmetros

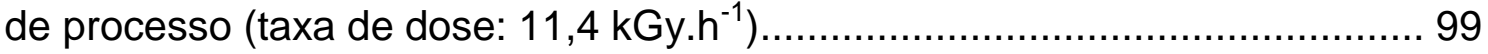




\section{INTRODUÇÂO}

"O Brasil esta enfrentando uma série de decisões políticas importantes que determinarão o futuro de seu setor de energia ao logo das próximas décadas, com consideráveis consequências sobre a competitividade econômica do país, bem estar de sua população, e o clima global. As decisões se referem ao direcionamento de aproximadamente 0,5 trilhão de dólares de investimentos iniciais em infraestrutura energética ao longo da próxima década - o que poderá reforçar o Brasil numa estrutura intensiva em carbono, ou impulsionar o país em uma posição de líder na economia de baixo carbono" (LUCON et al., 2015).

Os efeitos irreversíveis das emissões de gases de efeito estufa, procura por fontes de energia sustentáveis, necessidade de segurança energética, aliados a maior conscientização das questões ambientais e uma potencial escassez de recursos naturais, forçaram a imigração de combustíveis fosseis baseados em hidrocarbonetos para fontes renováveis e aceleram as pesquisas na área de conversão e armazenamento de energia (MAURYA et al., 2015).

As células a combustível por serem sistemas que convertem a energia química em energia elétrica tornaram-se dispositivos eficazes na redução da emissão de dióxido de carbono proveniente da combustão de automóveis e usinas termoelétricas, já que reduzem a utilização de combustíveis fósseis. Tendo como fontes de energia o hidrogênio e o oxigênio, as células a combustível são consideradas sistemas de energia limpa (JEONG et al., 2015). Esses sistemas constituem uma tecnologia alternativa de energia de grande eficiência, apresentando uma vasta aplicabilidade nas áreas de energia portátil, estacionária e automotiva desde o uso residencial, comercial e industrial, sistemas de co-geração (aproveitamento do próprio calor gerado pelo sistema), navios e submarinos, veículos de passeio e ônibus, alimentação de equipamentos eletrônicos, em particular na substituição de baterias em telefones celulares, computadores, calculadoras, entre outros. (SATEER, 2000; CAO et al., 2012; BROUZGOU et al., 2013). 
Neste contexto, as células a combustível alcalinas (AFCs), utilizam membranas condutoras de íons hidroxila $\left(\mathrm{OH}^{-}\right)$como eletrólito, ganharam interesse dos pesquisadores devido às potenciais vantagens em relação às células a combustível protônicas (PEM), condutoras de íons $(\mathrm{H}+)$, entre elas: (i) facilidade da reação de redução do oxigênio, possibilitando a utilização de catalisadores metálicos menos nobres que a platina; (ii) meio menos corrosivo possibilitando o uso de materiais de menor custo, (iii) menor crossover de combustíveis, especialmente alcoóis, possibilitando o uso de membranas de menor custo, (iv) melhor gerenciamento de água, e (v) menor envenenamento por $\mathrm{CO}_{2}$ (ZHOU et al., 2015; CHENG et al., 2015).

As membranas trocadoras de ânions (AEMs) são uma alternativa promissora para o desenvolvimento de eletrólitos mais eficientes para as células a combustível alcalinas (AFCs). As células a combustível alcalinas (AFCs) pertencem à classe das células a combustível de baixa temperatura (abaixo de $100^{\circ} \mathrm{C}$ ) e apresenta como principal característica a utilização de um eletrólito aniônico, com base em íons hidroxila (OH-).( CHENG et al., 2015). Historicamente, a AFC foi a tecnologia escolhida para utilizada em programas espaciais americanos na década de 1960. As AEMs são membranas ionoméricas capazes de transportar os íons hidroxila $\left(\mathrm{OH}^{-}\right)$por meio de grupos quaternário de amônio $\left(-\mathrm{NR}_{3}\right)$ e tem como característica um elevado $\mathrm{pH}$ equivalente (BROUZGOU et al., 2013).

A membrana de troca aniônica é um dos componentes principais das células a combustível e tem um papel fundamental no seu desempenho, sendo responsáveis pelo transporte de íons hidroxila $\left(\mathrm{OH}^{-}\right)$produzidos no catodo para o anodo, onde ocorrem reações eletroquímicas entre os íons hidroxila $\left(\mathrm{OH}^{-1} \mathrm{e} o\right.$ combustível gerando elétrons. A membrana serve também como barreira entre os dois eletrodos, prevenindo o crossover de combustíveis, principalmente alcoóis, e a ocorrência de curto circuito (CHENG et al., 2015).

Embora as células a combustível alcalinas tenham vantagens em relação às células a combustível protônicas, alguns desafios ainda permanecem: insuficiente condutividade iônica da membrana, alta resistência da membrana reduzindo a eficiência da célula, menor estabilidade química e mecânica da 
membrana, envenenamento com $\mathrm{CO}_{2}$, e disponibilidade de ionômeros adequados. (MAURYA et al., 2015; WANG et. al, 2013; CHENG et al., 2015; VARCOE et al., 2014).

A baixa condutividade iônica pode ser atribuída à menor condutividade dos íons hidroxila $(\mathrm{OH}-)$ que os íons $(\mathrm{H}+)$ na fase aquosa. Como alternativa para melhorar a condutividade iônica, geralmente a membrana necessita de índices de capacidade de troca iônica (IEC) altos, o que por sua vez, pode causar modificações na membrana como, excessiva absorção de água ocasionando redução e, em alguns casos, a perda das propriedades mecânicas. (ZHOE et al., 2015; Wang et al., 2013; CHENG et al., 2015; VARCOE et al., 2014)

A estabilidade química, mecânica e térmica das membranas aniônicas, dependem da natureza dos grupos funcionais capazes de transportar os ânions hidroxilas e também da cadeia do polímero base. Alem disso, as condições de operação da célula, temperatura e alcalinidade do meio ( $\mathrm{pH}$ básico). Podem contribuir para a degradação dos grupos funcionais e do polímero.

Pesquisadores buscam encontrar caminhos para desenvolver membranas aniônicas com satisfatória condutividade iônica, e estabilidade química, mecânica e térmica, estudam alternativas de grupos catiônicos e cadeias poliméricas. Entretanto, a estabilidade alcalina ainda não foi solucionada pelas atuais polímeros desenvolvidos.

Este trabalho pretende, portanto, contribuir para a pesquisa e 0 desenvolvimento de membranas aniônicas obtidas pelo processo de enxertia por irradiação, química e termicamente estáveis e com satisfatória condutividade iônica para aplicação em células a combustível. Esta contribuição é alcançada ao sintetizar e caracterizar membranas alcalinas com polímeros LDPE (polietileno de baixa densidade), UHMWPE (polietileno de ultra alto peso molecular), poli(etileno-co-tetrafluoroetileno) (PETFE) e poli(tetrafluoroetileno-co-hexafluoroetileno) (PFEP). Avaliar parâmetros de processo de irradiação e enxertia, e propor método de monitoramento da estabilidade dos radicais livres utilizando a técnica de EPR, formados no processo de irradiação. 


\section{OBJETIVOS}

\subsection{Objetivo geral}

Sintetizar membranas aniônicas química e termicamente estáveis com satisfatória condutividade iônica para aplicação em células a combustível alcalinas.

\subsection{Objetivos específicos}

- Sintetizar membranas condutoras de ânions (íons hidroxila) baseados nos polímeros polietileno de baixa densidade (LDPE), polietileno de ultra alto peso molecular (UHMWPE), poli(etileno-co-tetrafluoroetileno (PETFE) e poli(tetrafluoroetileno-co-hexafluoroetileno) (PFEP) enxertados com monômero de estireno, via irradiação nos processos simultâneo ou de pré-irradiação nas fontes gama $\left({ }^{60} \mathrm{Co}\right)$ ou feixe de elétrons.

- Funcionalizar as membranas com trimetilamina.

- Estudar o tempo de vida dos radicais livres gerados no processo de irradiação dos polímeros de LDPE, UHMWPE, PETFE e PFEP por espectroscopia de ressonância paramagnética eletrônica (EPR).

- Caracterizar as membranas por espectroscopia Raman.

- Determinar gravimetricamente o grau de enxertia das membranas.

- Determinar a capacidade de troca iônica por titulação indireta das membranas.

- Avaliar a condutividade iônica das membranas por espectroscopia de impedância (EIS). 


\section{REVISÃO DA LITERATURA}

A célula a combustível é um sistema eletroquímico, de operação contínua que converte a energia química armazenada de um combustível (hidrogênio, gás natural, etanol ou outros hidrocarbonetos) e de um agente oxidante (geralmente oxigênio do ar) diretamente em energia elétrica por meio de reação de óxido redução. As células a combustível operam com alta eficiência, níveis de emissão de poluentes e ruídos muito abaixo dos padrões internacionais de emissão de poluentes, e com aplicação nas áreas: automotiva e transporte em geral; sistemas portáteis e unidades auxiliares de energia (APU) (KORDESCH e SIMADER, 1996; BROUZGOU et al., 2013). As células a combustível, a princípio, podem fornecer energia com eficiências termodinâmicas superiores a $80 \%$, em comparação com as energias de combustão convencionais, limitadas pela eficiência do ciclo de Carnot (WANG et al., 2013).

Existem cinco tipos de células a combustível, sendo a classificação baseada no tipo de eletrólito utilizado e, por consequência na temperatura de operação. Os tipos existentes são: célula a combustível alcalina (AFC); célula a combustível de membrana de troca protônica (PEMFC); célula a combustível de ácido fosfórico (PAFC); célula a combustível de carbonato fundido (MCGC), e célula a combustível de óxido sólido (SOFC) (LINARDI, 2010).

As células a combustível de membrana de troca protônica (PEMFC) e a célula a combustivel alcalina (AFC) são células a combustível de baixa temperatura de operação (faixa de temperatura de aproximadamente 60 a $90 \stackrel{\circ}{\circ}$ ) e podem ser aplicados ao transporte e dispositivos portáteis.

A célula a combustível de membrana de troca protônica (PEMFC) usa uma membrana polimérica de troca protônica funcionalizada com grupos ácidos (grupos sulfônicos $\left(-\mathrm{SO}_{3}\right)$ ) do tipo $\mathrm{Nafion}^{\mathrm{TM}}$, ou outra membrana semelhante condutora de prótons, como eletrólito. As reações envolidas neste tipo de célula são: a oxidação do hidrogênio no anodo, e a readução do oxigênio no cátodo. 
O desenvolvimento de membranas poliméricas de alta eficiência como o Nafion $^{\mathrm{TM}}$, desenvolvida pela DuPont Co. em 1962, permitiu um avanço de tecnologia de células a combustível com eletrólitos aquosos ácidos e de membranas trocadoras de prótons que podem operar em temperaturas de até $250{ }^{\circ} \mathrm{C}$ (TICIANELLI e GONZALEZ, 2013). Além do Nafion ${ }^{\mathrm{TM}}$, diversas membranas de troca protônica estão comercialmente disponiveis, entre elas: Aciplex (Asahi Chemical Industry Co.); DOW (DOW), Flemion ${ }^{\mathrm{TM}}$ (Asahi Glass Co. Ltd.) (XU, 2005).

O Nafion ${ }^{\mathrm{TM}}$ é um copolímero perfluorado contendo grupos de ácidos nas cadeias laterias (grupos sulfônicos), produzido a partir da polimerização do monômero de tetrafluoroetileno (TFE) com o grupo lateral éter-vinila perfluorado e sulfatado na terminação (MAURITZ e MOORE, 2004). A cadeia de PTFE confere excelente resistência química, enquanto as cadeias laterais promovem a capacidade de troca iônica. As membranas de Nafion ${ }^{\mathrm{TM}}$ estão disponíveis em diversas capacidades de troca protônica e espessuras, entre elas, Nafion ${ }^{\mathrm{TM}} 120,117,112$ (XU, 2005). As membranas membranas Nafion ${ }^{\mathrm{TM}}$ e Dow foram desenvolvidas e empregadas com sucesso (FIG.1) (MAURYA et.al, 2015).

(A)

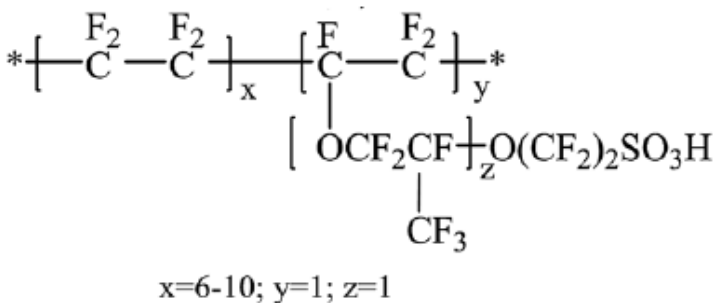

(B)

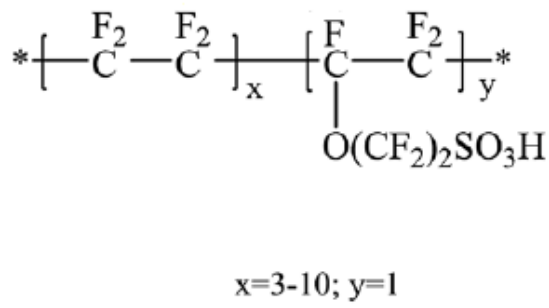

FIGURA 1 - Estruturas químicas das membranas perfluoradas: (A) Nafion ${ }^{\mathrm{TM}}$ e (B) DOW $^{\mathrm{TM}}$ (MAURYA et.al, 2015).

O Nafion ${ }^{\mathrm{TM}}$, quando hidratado, apresenta alta condutividade protônica (cerca de $10^{-2} \mathrm{Scm}^{-1}$ a temperatura ambiente), estabilidade química, mecânica e dimensional. Entretanto, a alta permeabilidade ao metanol e seu alto custo 
impedem o uso em células a combustivel de metanol direto (DMFC) e a sua comercialização em massa.

Os setores de transporte e portáteis são os segmentos de mercado de maior interesse na aplicação de células das PEMFCs, devido a sua baixa temperatura de operação $\left(<100^{\circ} \mathrm{C}\right)$ aliadas a possibilidade de redução na emissão de gases poluentes e da poluição sonora. As indústrias automotivas Daimer-Chysler, Ford, General Motors, Honda, Mazda, Peugeot-Citroen PSA, Renault, e Toyota anteciparam os estudos nesta tecnologia como alternativa para a substituição dos motores de seus veículos. Entretanto, o alto custo da membrana e do catalisador ainda representam desafios para a aplicação/comercializaçao das PEMFCs (COUTURE et al., 2011). As empresas Honda e Toyota lançaram os primeiros automóveis hídridos Clarity e Mirali utilizando tecnologia híbrida que combina motor elétrico e célula a combustível a higrogênio (PEMFCs) em 2015 (OLIVEIRA, 2015).

A célula a combustivel alcalina (AFC) é constituinte da classe das células a combustível de baixa temperatura de operação (abaixo de $100^{\circ} \mathrm{C}$ ), utiliza um eletrólito aniônico baseado em íons hidroxila $\left(\mathrm{OH}^{-}\right)$e tem como principais características exibir excelentes desempenhos energéticos, quando operadas com hidrogênio e oxigênio puros, e dispensar o uso de catalisadores de metais nobres (BROUZGOU et al., 2013). Historicamente, a AFC foi a tecnologia utilizada nos programas espaciais americanos na década de 1960s (COUTURE et al., 2011).

Originalmente, as células a combustível alcalinas utilizavam soluções concentradas de hidróxido de sódio ou potássio impregnado em matrizes sólidas como eletrólito. Essa configuração foi, mais tarde, considerada um sério problema das AFCs, já que a progressiva carbonatação do eletrólito, resultante da reação do álcali com o dióxido de carbono $\left(\mathrm{CO}_{2}\right)$ proveniente do ar, diminuia gradativamente a condutividade do eletrólito e passivava a superficie do eletrodo (Eq.1) (KORDESCH e CIFRAIN, 2004; BROUZGOU et al., 2013;. COUTURE et al., 2011)

$\mathrm{CO}_{2}+2 \mathrm{KOH} \longrightarrow \mathrm{K}_{2} \mathrm{CO} 3+\mathrm{H}_{2} \mathrm{O}$

[Eq. 1] 
Uma alternativa aos eletrólitos líquidos impregnados em matrizes sólidas foi o uso de eletrólito líquido circulante, soluções de hidróxido de sódio ou potássio, que, apesar das reconhecidas vantagens no gerenciamento de água e calor e da fácil remoção de carbonatos e impurezas, requer a utilização de periféricos (bombas, tanques, tubos, entre outros) altamente resistentes à corrosão e de alto custo (VIELSTICH et al., 2003; KORDESCH e CIFRAIN, 2004; BROUZGOU et al., 2013).

Recentemente, o desenvolvimento de membranas aniônicas para aplicação como eletrólitos em células alcalinas, ou seja, com o mesmo princípio de funcionamento das membranas trocadoras de prótons, que compõem as PEMFCs, iniciou-se um novo campo de pesquisa na área de células a combustível de baixa temperatura (KORDESCH e CIFRAIN, 2004; BROUZGOU et al., 2013). Os eletrólitos sólidos, mais especificamente as membranas trocadoras de ânions (AEM do inglês Anion Exchange Membrane), são uma alternativa promissora na área de desenvolvimento de eletrólitos mais eficientes para células a combustível alcalinas, sendo essa nova classe de AFC denominada de célula a combustível de troca aniônica (AEMFC, do inglês Anion Exchenge Membrane Fuel Cell).

Em geral, as AEMs são membranas ionoméricas hidratadas, assim como as membranas trocadoras de prótons (PEM) utilizadas nas PEMFCs, que conduzem íons hidroxila $\left(\mathrm{OH}^{-}\right)$por meio do grupo amônio quaternário e têm como característica um elevado pH equivalente (BROUZGOU et al., 2013). As principais vantagens das AEMFCs, quando comparadas às convencionais AFCs, são: i) minimiza a precipitação de carbonatos, ii) não há variação na concentração do eletrólito; iii) o gerenciamento de água é simplificado, já que a água é produzida no ânodo e consumida no cátodo; iv) reduzida corrosão de materiais, v) reduzido crossover de combustíveis no caso do etanol como combustível (BROUZGOU et al., 2013; LARMINIE e DICKS, 2003).

Assim como ocorrem nos diferentes tipos de células a combustível, a reação de formação de água é a reação fundamental das células a combustível alcalinas. As reações eletroquímicas se baseiam na oxidação de hidrogênio, na presença de íons hidroxila com a formação de água e transferência de quatro elétrons via circuito externo e reação de redução de oxigênio por meio da combinação com água e elétrons transferidos do ânodo para a formação de 
novos íons hidroxila (LARMINIE e DICKS, 2003). Na FIG.2 é mostrado o esquema simplificado de uma célula a combustível alcalina de membrana de troca aniônica, as reações e a direção do transporte dos íons e elétrons.

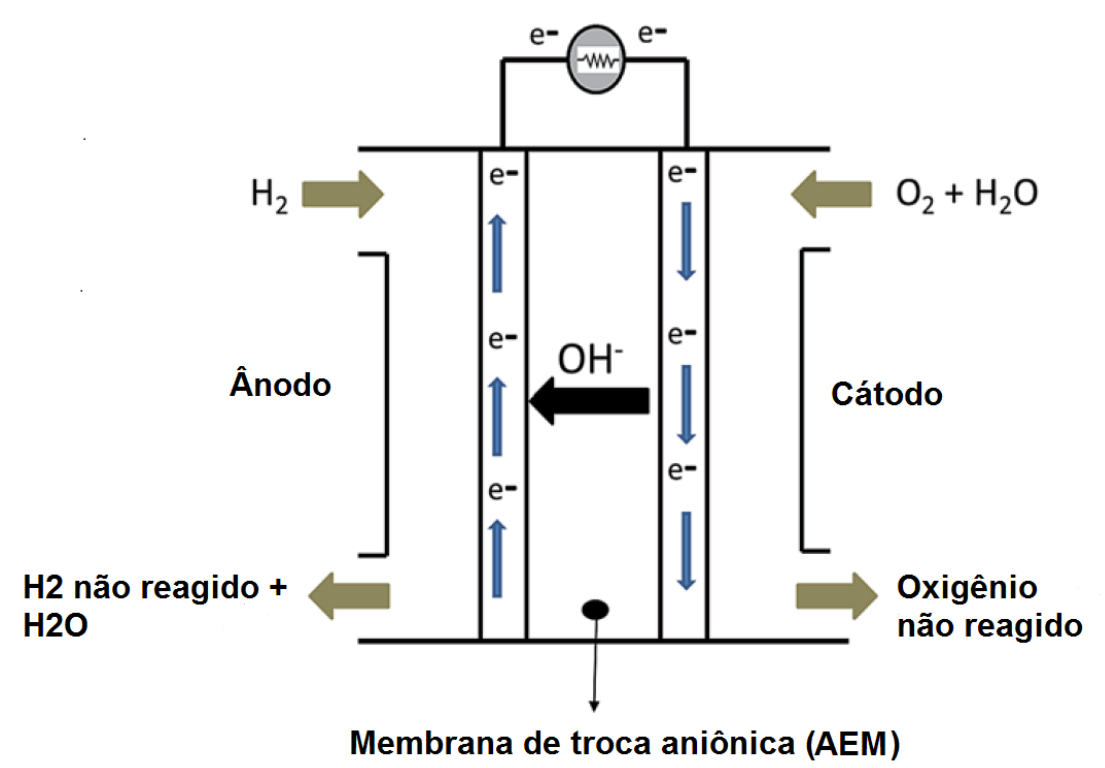

Ânodo

$$
2 \mathrm{H}_{2}+4 \mathrm{OH}^{-} \rightarrow 4 \mathrm{H}_{2} \mathrm{O}+4 \mathrm{e}^{-}
$$

Cátodo

$$
\mathrm{O}_{2}+4 \mathrm{e}^{-}+2 \mathrm{H}_{2} \mathrm{O} \rightarrow 4 \mathrm{OH}^{-}
$$

Reação geral

$$
2 \mathrm{H}_{2}+\mathrm{O}_{2} \rightarrow 2 \mathrm{H}_{2} \mathrm{O}
$$

FIGURA 2 - Esquema simplificado de uma célula a combustível alcalina de membrana de troca aniônica, as reações e a direção do transporte dos íons e elétrons. Adaptada de (MAURYA et al., 2015).

O elemento eletroquímico básico da AEMFC é $O$ conjunto eletrodos/membrana (MEA) (do inglês, Membrane Electrode Assembly), constituído por uma membrana polimérica (ionômero/ eletrólito) intercalado entre dois eletrodos de difusão de gás, como mostra a FIG. 3. Os eletrodos de difusão de gás são constituídos por duas camadas porosas, a camada difusora ao lado do gás e a camada catalisadora colocada em contato com o eletrólito. (TICIANELLI e GONZALEZ, 2013; GUBLER, 2014). As reações eletroquímicas ocorrem na camada do catalisador, a qual tem cerca de $10 \mu \mathrm{m}$ de espessura e é composta por uma mistura de catalisador e ionômero (GUBLER, 2014). 


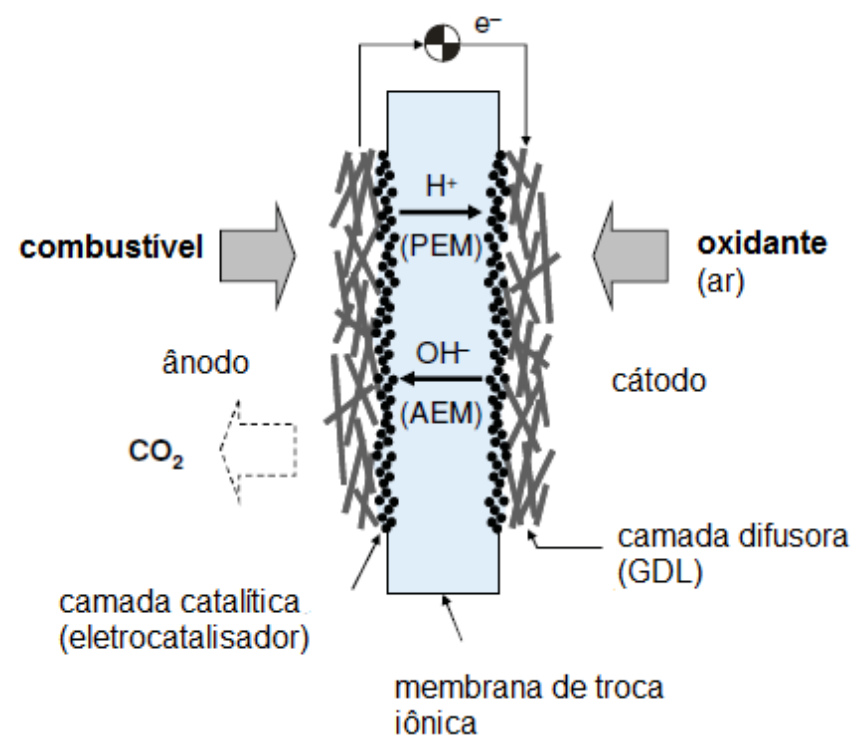

FIGURA 3 - Esquema simplificado de um MEA (conjunto eletrodos/membrana) de uma célula do tipo PEFC (célula a combustível de eletrólito polimérico) (GUBLER, 2014).

A AEM como componente principal da célula a combustível alcalina tem um papel fundamental no desempenho da célula. A função principal da AEM é transportar os íons hidroxila $\left(\mathrm{OH}^{-}\right)$produzidos no cátodo para o ânodo, onde os íons hidroxilas sofrem reações eletroquímicas com o combustível para gerar elétrons. A AEM serve também como separadora entre os dois eletrodos, prevenindo a passagem do combustível do compartimento anódico para o catódico (efeito crossover) despolarizando a célula e reduzindo sua potência, e a ocorrência de curto circuito (CHENG et al., 2015).

Em geral, as AEMs podem ser formadas por polímeros base nãofluorados, parcialmente fluorados ou totalmente fluorados, tais como poli(étersulfona) (PES), poli(óxido de fenileno) (PPO), poli(ftalazina-éter-sulfona-cetona) (PPESK), polietileno (PE), poli(fluoreto de vinilideno) (PVDF), poli(etileno-cotetrafluoroetileno) (PETFE) e poli(tetrafluoroetileno-co-hexafluoropropileno) (PFEP), e com cadeias laterais covalente ligadas à estrutura do polímero-base, que sustentam os grupos catiônicos quaternários de amônio responsáveis pela condução dos íons hidroxila. Essas cadeias laterais podem ser incorporadas no polímero base pela copolimerização de monômeros utilizando o processo de 
enxertia por irradiação formando um copolímero enxertado com propriedades modificadas ou totalmente novas. Uma das principais características deste processo é a utilização de filmes poliméricos pré-fabricados como polímero base, tornando o processo de produção de $A E M s$ mais fácil e rápido (MANLOUK et al., 2012).

O processo de enxertia por irradiação consiste na reação de adição de monômeros ou oligômeros à cadeia principal de um polímero utilizando uma técnica físico/química, em geral são adicionados grupos funcionais hidrófilos a substratos hidrofóbicos e vice-versa (BRADLEY, 1984; WANG et al., 2013). Em seguida, o monômero enxertado pode ser funcionalizado com a adição de grupos funcionais de amônio, fosforados, sulfônico, piridino, guanidino, ou imidazolino de acordo com as propriedades requeridas pela membrana. Se o monômero já possuir grupos iônicos, esta etapa pode ser ignorada. (WANG et al., 2013; ZHOU et al., 2015).

Para promover uma distribuição homogênea dos grupos funcionais na totalidade da cadeia do polímero, é necessário o uso de energias de alta energia capazes de penetrar e induzir a ionização de toda a cadeia polimérica. As radiações mais usadas nos processo de enxertia por irradiação são as radiações ionizantes como: raios gama, elétrons acelerados, ultra violeta (UV) e plasma (BRADLEY, 1984; ZHOU et al., 2015). Os processos industriais de irradiação de polímeros são realizados em irradiadores de ${ }^{60} \mathrm{Co}$ e aceleradores de elétrons.

A fonte de radiação gama mais utilizada é ${ }^{\circ}{ }^{60} \mathrm{Co}$, com emissões de radiações de 1,17 e 1,33 MeV (valor médio 1,25 MeV), devido à facilidade de preparação, custo baixo e tempo de meia vida ( 5,3 anos). Outra fonte de radiação gama bastante utilizada é o césio $\left({ }^{137} \mathrm{Cs}\right)$, que oferece emissões de energias menores (0,66 MeV) (TABATA, 1928; SPINKS e WOODS, 1990; NASEF e HEGAZY, 2004).

As radiações com cargas, como os elétrons, são obtidas a partir de aceleradores de elétrons, os quais estão disponíveis comercialmente em diferentes projetos e energia. Os aceleradores de elétrons podem ser classificados de acordo com a faixa de energia (que determina o seu poder de penetração e sua aplicação), em três categorias: aceleradores de baixa energia 
$(0,1-0,5 \mathrm{MeV})$, média energia $(0,5-5,0 \mathrm{MeV})$ e alta energia $(5,0-10,0 \mathrm{MeV})$ (TABATA, 1928; SPINKS e WOODS, 1990; NASEF e HEGAZY, 2004).

Esses dois tipos de irradiação causam essencialmente os mesmos eventos microscópicos nos polímeros irradiados, e as transformações resultantes não dependem da natureza da radiação. No entanto, elétrons e fótons têm uma profundidade de penetração diferente. A fonte gama fornece maior poder de penetração com modo de operação simples a custo mais baixo, enquanto que no feixe de elétrons a taxa dose é alta taxa e com radiação bem direcionada, os processos são curtos e com custos relativamente altos (NASEF e HEGAZY, 2004). Para as partículas com carga, um parâmetro que descreve a transferência de energia para o substrato por unidade de comprimento para um dado tipo de radiação é a transferência de energia linear (LET, do inglês linear energy transfer) (GUBLER, 2014).

O objetivo de expor um polímero à radiação ionizante é o de criar sítios ativos que possam iniciar a reação de enxertia quando o filme do polímero estiver em contato com o monômero. Os sítios ativos podem ser radicais presos a cadeia do polímero (R·), no caso do polímero ser irradiado e mantido em atmosfera inerte; ou sítios iônicos (catódicos ou anódicos) se a enxertia for realizada via mecanismo iônico.

Entre as vantagens do uso da radiação pode-se citar: (i) versatilidade, disponibilidade e variedade de polímeros base e monômeros para enxertia, (ii) distribuição homogênea dos sítios ativos criados na membrana, (iii) processo simples e efetivo, a reação de enxertia pode ser realizada a temperatura ambiente ou a baixas temperaturas, e sem uso de catalisadores ou iniciadores de polimerização, (iv) custo benefício, a reação de enxertia é iniciada por raios gama ou elétrons acelerados sem uso de iniciadores ou catalisadores, reduzindo o custo e produzindo um copolímero mais puro e mais limpo, (v) menor/menos exigências na seleção do tipo de polímeros em termos de forma e estrutura (ZHOU et al., 2015).

A interação da radiação ionizante com a matéria produz íons e moléculas excitadas a partir das reações primárias de ionização e excitação. Enquanto íns e moléculas podem gerar diretamente produtos quimicamente estáveis; em alguns sistemas podem ocorrer à formação de radicais livres devido às 
reações secundárias (recombinação e dissociação). As reações primárias e secundárias foram sumarizadas na TAB.1 (BRADLEY, 1984; WOODS e PIKAEV, 1994).

Tabela 1 - Reações decorrentes da interação da radiação ionizante com a matéria . (BRADLEY, 1984; WOODS e PIKAEV, 1994).

\begin{tabular}{|c|c|}
\hline Reações Primárias & \\
\hline $\mathrm{AB} \rightarrow \mathrm{AB}^{+}+\mathrm{e}^{-}$ & lonização \\
\hline $\mathrm{AB} \stackrel{\mathrm{e}-}{\longrightarrow} \mathrm{AB}^{*}$ & Excitação \\
\hline \multicolumn{2}{|l|}{ Reações Secundárias } \\
\hline $\mathrm{AB}^{+}+\mathrm{e}^{-} \longrightarrow \mathrm{AB}^{*}$ & Recombinação íon- elétron \\
\hline $\mathrm{AB}^{+}+\mathrm{e}^{-} \longrightarrow \mathrm{AB}^{-}$ & \\
\hline $\mathrm{AB}^{+} \mathrm{XY^{- }} \rightarrow \mathrm{AB}^{\star}+\mathrm{XY}^{*+}$ & Combinação molécula-elétron \\
\hline $\mathrm{AB}^{+}+\mathrm{AB} \rightarrow \mathrm{AB}_{2}+\mathrm{A}$. & Interação íon positivo-negativo \\
\hline $\mathrm{AB}^{+} \longrightarrow \mathrm{A}^{+} \cdot+\mathrm{B}$ & Reação íon-molécula \\
\hline \multicolumn{2}{|l|}{$A B^{*} \rightarrow A \cdot+B$} \\
\hline $\mathrm{A} \cdot+\mathrm{C} \rightarrow \mathrm{AC}$. & $\begin{array}{l}\text { Dissociação molecular (ligação } \\
\text { cruzada e enxertia) }\end{array}$ \\
\hline $\mathrm{AC} \cdot+\mathrm{C} \rightarrow \mathrm{ACC}$ & \\
\hline $\mathrm{A} \cdot+\mathrm{BR} \rightarrow \mathrm{AR}+\mathrm{B}$ & Abstração de radical \\
\hline$A \cdot+B \cdot \rightarrow A B$ & Recombinação de radicais \\
\hline $\mathrm{RH} \cdot+\mathrm{DH} \rightarrow \mathrm{RH}_{2}+\mathrm{D}$ & Transferência de hidrogênio \\
\hline $\mathrm{AB}^{*} \longrightarrow \mathrm{C}+\mathrm{D}$ & Dissociação \\
\hline $\mathrm{AB}^{+} \longrightarrow \mathrm{C}^{+}+\mathrm{D}$ & \\
\hline
\end{tabular}


Os eventos envolvidos no processo de irradiação podem ser representados pelo esquema mostrado na FIG 4.

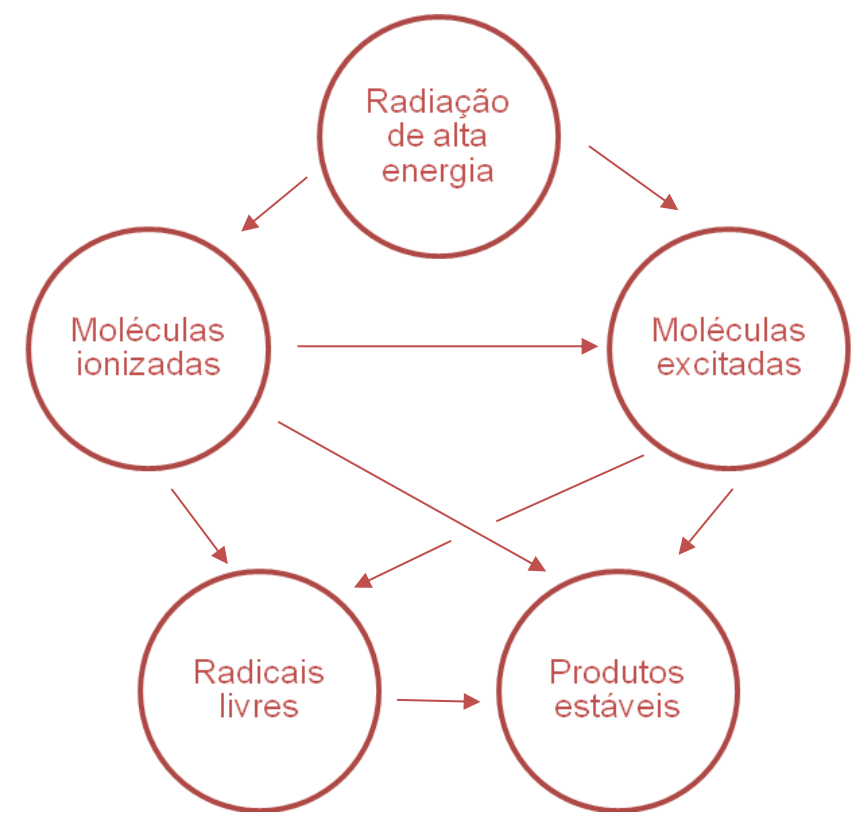

FIGURA 4 - Esquema dos eventos envolvidos na radiação induzida. Adaptado de BRADLEY, 1984

A preparação das membranas funcionais e de troca iônica por copolimerização de enxertia induzida por irradiação pode ser realizada por reação de monômeros funcionalizados ou não-funcionalizados por meio dos processos de irradiação simultâneo e de pré-irradiação, os quais podem ser realizados em presença de ar (peroxidação), vácuo, ou atmosfera inerte $\left(\mathrm{N}_{2}\right.$ (nitrogênio) ou $\operatorname{Ar}$ (argônio)). O tipo de espécies radicalares que serão formadas tem relação com a atmosfera empregada durante o processo de enxertia.

A reação entre o monômero e os radicais (peróxidos e radicais) formados durante a irradiação dos polímeros é regida pelas propriedades de difusão do monômero e o tempo de vida dos sítios reativos. Em geral, as reações de enxertia por irradiação são realizadas em soluções de monômeros. A utilização de solventes adequados facilita o intumescimento do polímero base facilitando a difusão do monômero à camadas mais internas do polímero resultando em um grau de enxertia maior e mais uniforme. (RAGER, 2003; WALSBY et al., 2001; POYTON e VARCOE, 2015). A homogeneidade da enxertia em toda a 
espessura da membrana é fundamental para a obtenção de condutividade iônica efetiva (POYTON e VARCOE, 2015). WALSBY et al. (2001) e RAGER (2003), observaram que os solventes mais favoráveis para a enxertia do PFEP utilizando o monômero de estireno foram na seguinte ordem água:propano-2-ol $>$ propanol-2-ol $>$ metanol $>$ THF $>$ ciclohexano $>$ tolueno. Segundo NASEF et al.(2008), filmes de PETFE apresentaram intumescimento decrescente nos seguintes solventes tolueno $>$ dimetilformamida >> propano-2-ol > etanol > metanol. Estudos recentes realizados por POYTON e VARCOE (2015) e WANG et al. (2017) mostraram que os teores de VBC podem ser reduzidos para 20 e $5 \%$ respectivamente em soluções de água e propano-2-ol e surfactantes.

O uso de monômeros funcionalizados confere diretamente características iônicas ao polímero base e são classificados pelo caráter ácido ou básico, como por exemplo, cloreto de vinil benzeno (VBC) que contem grupos $\left(\mathrm{Cl}^{-}\right)$na estrutura. Enquanto que, os monômeros não-funcionalizados, como estireno e alquil acrilado, podem ser ativados pós enxertia para conferir caráter iônico por meio de reação de sulfonação ((adição de grupos (-SO3) ao anel aromático do estireno)) (ZHOU et al., 2015; ROHANI et al., 2007). Os monômeros VBC, divinil benzeno (DVB), e o glicidilmetacrilato (GMA) que contem grupos epóxi e ligações $C-C L$ podem ser considerados como alternativas para melhorar a estabilidade química das membranas (JEONG et al., 2015).

No processo simultâneo de irradiação o polímero-base é irradiado na presença do monômero, que poderá estar na forma de vapor, líquido ou em solução. A irradiação poderá ser realizada em atmosfera inerte $\left(\mathrm{N}_{2}, \operatorname{Ar}\right)$ ou a vácuo, formando radicais livres ativos na matriz polimérica e no monômero. Apesar de ser mais eficiente, a princípio, a copolimerização por enxertia pelo processo simultâneo tem sérias limitações decorrentes do alto nível de formação de homopolímeros.

O mecanismo de reação do processo simultâneo pode ser representado pelas seguintes equações gerais de reação 5 a 9 (DENARO e JAYSON, 1972; NASEF e HEGAZY, 2004) 
Irradiação

Iniciação

Propagação

Terminação

i) por Combinação

ii) por Dismutação ou

desproporcionamento
[Eq. 5]

[Eq. 6]

[Eq. 7]
[Eq. 8]

[Eq. 9]

sendo: $(\mathrm{P})$ - polímero, $(\mathrm{M})$ - monômero, $(\cdot)$ - radical, $(\mathrm{PM} \cdot)$ - cadeia inicial do enxerto, $\left(\mathrm{PM}_{m}\right)$ - cadeias de crescimento do enxerto do copolímero.

As reações secundárias, recombinação (desativação dos radicais do polímero (P.) por recombinação mútua), e homopolimerização (reação entre os radicais do monômero formados a partir da radiólise do monômero com as moléculas de monômeros presentes na solução de enxertia) podem ser representadas pelas seguintes equações gerais de reação 10 a 13 (NASEF e HEGAZY, 2004):

Recombinação

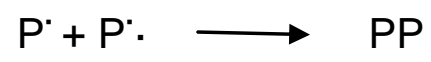

Homopolimerização

$$
\begin{aligned}
& \mathrm{M} \longrightarrow \mathrm{M}^{\cdot} \\
& \mathrm{M}^{\prime}+\mathrm{nM} \longrightarrow \mathrm{M}_{\mathrm{n}} \\
& \mathrm{M}_{\mathrm{n}}+\mathrm{M}_{\mathrm{m}} \longrightarrow \mathrm{M}_{\mathrm{n}+\mathrm{m}}
\end{aligned}
$$

sendo: $\left(M_{n}^{\prime}\right)$ - monômero e $\left(M_{n m}^{\prime}\right)$ - crescimento da cadeia do homopolímero.

O processo da pré-irradiação envolve a combinação de duas etapas: a irradiação do polímero base para a formação de radicais ativos e a reação de enxertia na presença dos monômeros. 
Se a irradiação ocorrer na presença de ar, os radicais gerados reagem com o oxigênio formando peróxidos e hidroperóxidos que, por decomposição térmica, iniciam o processo de enxertia após entrar em contato com o monômero. As reações gerais envolvidas na copolimerização do monômero na cadeia principal do polímero pelo processo de pré-irradiação, na presença de ar, são representadas a seguir, equações 14 a 17 (NASEF e HEGAZY, 2004):

Formação de hidroperóxidos

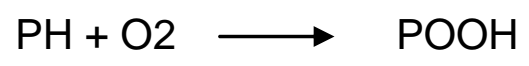

[Eq. 14]

Decomposição térmica

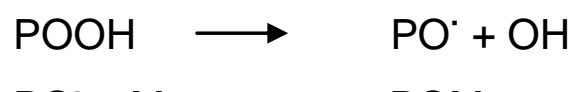

Iniciação

$\mathrm{PO}+\mathrm{M} \longrightarrow \mathrm{POM}$

Propagação

$\mathrm{POM}+\mathrm{nM} \rightarrow \mathrm{POM}{ }_{n+1}$

[Eq. 17]

sendo $(\mathrm{PH})$ - cadeia principal do polímero, $(\mathrm{POOH})$ - radical hidroperóxido, $(\mathrm{PO})$ - radical primário, $(\mathrm{POM})$ - cadeia inicial do enxerto, $\left(\mathrm{POM}_{n+1}\right)$ crescimento da cadeia de enxerto.

Por outro lado, se a irradiação for realizada sob vácuo ou em atmosfera inerte, os radicais gerados permanecem presos na matriz polimérica e a reação de enxertia se iniciará na presença dos monômeros como representado pelas equações de reação 18 e 19.

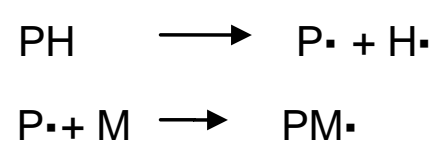

A estabilidade dos radicais ( $\mathrm{P} \cdot)$ e (PM·) depende principalmente da cristalinidade do polímero base, temperatura de estabilização e do período de armazenamento dos filmes irradiados (NASEF e HEGAZY, 2004): Na prática, o método de pré-irradiação tem sido preferido devido à menor formação de homopolímeros e também devido à possibilidade de realizar a enxertia a qualquer momento após irradiação prévia. 
O tempo de vida das espécies ativas formadas durante a irradiação dos polímeros (radicais, íons e peróxidos) é muito importante para o rendimento da enxertia e pode ser controlado tanto por armazenamento em baixas temperaturas (- 40 a $-80^{\circ} \mathrm{C}$ ) ou sob vácuo (NASEF e HEGAZY, 2004; LARSEN, et al., 2010; MITOV et al., 2006; GUPTA e SCHERER, 1994; KIZEWSKI et al., 2013). Em temperaturas altas (temperaturas positivas), as espécies ativas sofrem rápido decaimento como resultado de recombinação dos radicais na fase amorfa.

A perda de radicais durante 0 armazenamento influencia a reação de enxertia, com a consequente redução do número de centros ativos para a iniciação da polimerização, o que resulta em velocidade baixa de enxertia e rendimento baixo (LARSEN et al., 2010; MITOV et al., 2006). Como citado anteriormente, a estabilização das espécies radicalares produzidas pelo processo de pré-irradiação, para a realização posterior da enxertia, pode ocorrer por armazenamento em temperaturas negativas (-40 a $-80 \stackrel{\circ}{\circ}$ ). Diversos estudos comprovam a estabilidade dos radicais a baixas temperaturas, permitindo desta forma a preparação em uma única etapa e o armazenamento de grandes quantidades de filmes por longo tempo (GUPTA e SCHERER, 1994), de modo que as espécies adquiram mobilidade baixa o suficiente para não sofrerem reação, e produzirem enxertos mais homogêneos

Na TAB. 2 são apresentadas as características principais dos métodos de enxertia via irradiação simultânea e pré-irradiação: 
TABELA 2 - Características dos processos de enxertia pelo processo de irradiação simultânea e de pré-irradiação (NASEF e HEGAZY, 2004).

\begin{tabular}{|c|c|c|}
\hline Caracteristicas & Irradiação Simultânea & Pré-Irradiação \\
\hline Dose de radiação & Baixa & Alta \\
\hline Taxa de dose & Baixa & Sem restriçōes \\
\hline Atmosfera & Vácuo, nitrogênio & Vácuo, nitrogênio, ar \\
\hline Tipo de iniciação de radicais & Radicais livres & $\begin{array}{l}\text { Presos a matriz polimérica, Radicais } \\
\text { peróxido e hidroperóxidos }\end{array}$ \\
\hline Monômeros & Não funcionais & Funcionais \\
\hline Polimero base & Polimeros sensiveis à radiação & Polimeros sensiveis à radiação \\
\hline Efeito da homopolimerização & Alto & Baixo \\
\hline Temperatura & Não necessária & $\begin{array}{l}\text { Necessária para iniciar a reação de } \\
\text { copolimerização }\end{array}$ \\
\hline Tempo de reação & Relativo à dose de radiação & Não relacionado com a dose de radiação \\
\hline
\end{tabular}

Fonte - Adaptada de NASEF e HEGAZY, 2004

Os parâmetros que afetam a síntese de membranas ionoméricas podem estar relacionados com a fonte de radiação (natureza da radiação, taxa de dose e dose total) e/ou com a solução de enxertia e seus componentes (natureza do monômero, natureza do filme polimérico, concentração dos monômeros, adição de solventes, adição de agentes de reticulação, temperatura de reação, adição de inibidor, adição de ácidos, espessura do filme, entre outros) (NASEF e HEGAZY, 2004).

LAPPAN et al. (2009) estudaram o efeito das condições de irradiação na enxertia do monômero de estireno em filmes de PFEP pelo processo de préirradiação com feixe de elétrons $(1,5 \mathrm{MeV})$. Observaram que as resistências de tração e alongamento e o rendimento de enxertia foram fortemente influenciados pela temperatura de irradiação. Observaram também que a cisão da cadeia principal pode ser a causa da deterioração das propriedades mecânicas após tratamentos abaixo da temperatura de transição vítrea. 
HERMAN et al. (2003) avaliaram os efeitos dos parâmetros de irradiação e enxertia (tempo de imersão; dose total, temperatura e concentração do monômero) nas propriedades de membranas alcalinas PFEP copolimerizadas com cloreto de vinilbenzeno (VBC) pelo processo de pré-irradiação usando radiação gama. Resultados de enxertia de até $28,9 \%$ foram encontrados para tempos de enxertia de 48 horas a $50 \stackrel{\circ}{\circ}$.

\subsection{Estabilidades química, térmica e mecânica}

Um ponto fundamental no desenvolvimento das AEMs é a estabilidade química, mecânica e térmica dessas membranas, que são dependentes da natureza dos grupos funcionais capazes de transportar os ânions hidroxilas e também da cadeia do polímero base (GUPTA e SCHERER, 1994; HERMAN et al., 2003). Além da temperatura, a causa principal da degradação de vários grupos aniônicos e cadeias poliméricas é a alcalinidade do meio ( $\mathrm{pH}$ alto) Segundo BROUZGOU, et al. (2013) a decomposição dos grupos condutores de amônio quaternário pode ocorrer por reação de degradação de Hofmann, portanto é fundamental que estes grupos condutores permaneçam ligados a cadeia do polímero base, principalmente durante a operação da célula a combustível alcalina, quando valores de $\mathrm{pH}$ de até 14 podem ser atingidos.

Para atender aos requisitos de estabilidade mecânicos, químicos e térmicos, é recomendável que a membrana possua uma temperatura de transição vítrea $\left(T_{g}\right)$ abaixo da temperatura de operação para evitar qualquer alteração estrutural durante as reações químicas, e ser termicamente estável acima de $100 \stackrel{\circ}{\circ}$ (YAMAMOTO e TOI, 2011).

Neste sentido, desde o desenvolvimento da primeira membrana de troca aniônica por cientistas japoneses da empresa Tokuyama Soda utilizando policloropropileno reticulado com divinilbenzeno e funcionalizada com grupos quaternário de amônio via trimetilamina, vários estudos vêm sendo realizados envolvendo uma ampla variedade de polímeros, processos e técnicas de funcionalização e de caracterização, com o objetivo de desenvolver membranas aniônicas química e termicamente mais estáveis (COUTURE et al., 2011). 
Similarmente, El Moussaoui e Martin, da empresa Solvay, desenvolveram AEMs baseadas em filmes PETFE e PE irradiados e enxertados com monômero de estireno, funcionalizadas com clorosulfona e amônio para obter grupos quaternários de sulfonamida de amônio (COUTURE et al., 2011).

Entre as membranas aniônicas comercialmente disponíveis utilizadas como eletrólitos em AEMFCs, destacam-se as membranas Tokuyama ${ }^{\text {TM }}$ A201 (Tokuyama Co. Ltda), e New-Selemion ${ }^{\mathrm{TM}}$ (Asahi Glass Co. Ltda) que são utilizadas como eletrólitos em células a combustível alcalinas (AEMFCs) (COUTURE et al., 2011; MERLE et al., 2011). As membranas MORGANE ${ }^{\text {TM }}$ ADP (Solvay, S.A) e Tokuyama ${ }^{\text {TM }}$ AHA foram utilizadas em vários estudos como eletrólitos sólidos em células a combustível alcalinas de metanol direto (DMAFCs) (COUTURE et al., 2011; MERLE et al., 2011).

A natureza do polímero base é um parâmetro muito importante e precisa ser cuidadosamente trabalhado para fornecer as propriedades necessárias para a membrana, entre elas: i) facilidade de gerar radicais livres estáveis quando expostos à radiação que possam iniciar a reação de enxertia, e possuírem resistência à degradação radiolítica; ii) o material deve ser hidrofóbico para promover a separação de fase hidrofílica-hidrofóbica na membrana de troca aniônica; iii) deve permitir a difusão do monômero enxertado nas camadas internas do filme do polímero; d) o polímero base deve possuir estabilidade térmica, resistência mecânica, além estabilidade química aos reagentes químicos utilizados na síntese da membrana e no meio alcalino de operação da célula a combustível (NASEF e HEGAZY, 2004; GUBLER, 2014).

As principais alterações químicas induzidas em polímeros pelo processo de irradiação são: cisão da cadeia principal, formação de reticulações, liberação de produtos voláteis, criação de insaturações, e ciclização. $\mathrm{Na}$ presença de oxigênio, formam-se peróxidos (POOP.) e eventualmente hidroperóxidos $(\mathrm{POOH})$ que se decompõem por aquecimento para produzir radicais livres ativos durante o processo de enxertia. Por outro lado, em atmosfera inerte são gerados radicais livres imobilizados na cadeia do polímero, ficando desta forma impedidos de se recombinarem devido à reduzida mobilidade da cadeia polimérica na fase sólida. O rendimento da formação das espécies de radicais $G(R \cdot)$ é geralmente determinado por 
ressonância paramagnética eletrônica (EPR) (GUBLER, 2014). A ocorrência desses efeitos depende das propriedades intrínsecas do polímero base.

Os filmes de polímeros a base de hidrocarbonetos e fluoropolímeros podem ser usados como polímeros base para síntese/obtenção de membranas aniônicas pelo processo de enxertia por irradiação. Os polímeros mais utilizados para a síntese de membranas aniônica foram apresentados na TAB.3.

TAB. 3 - Polímeros utilizados na síntese de membranas aniônicas utilizando o processo enxertia via irradiação (DARGAVILLE et al., 2003; GLUBER et al., 2005)

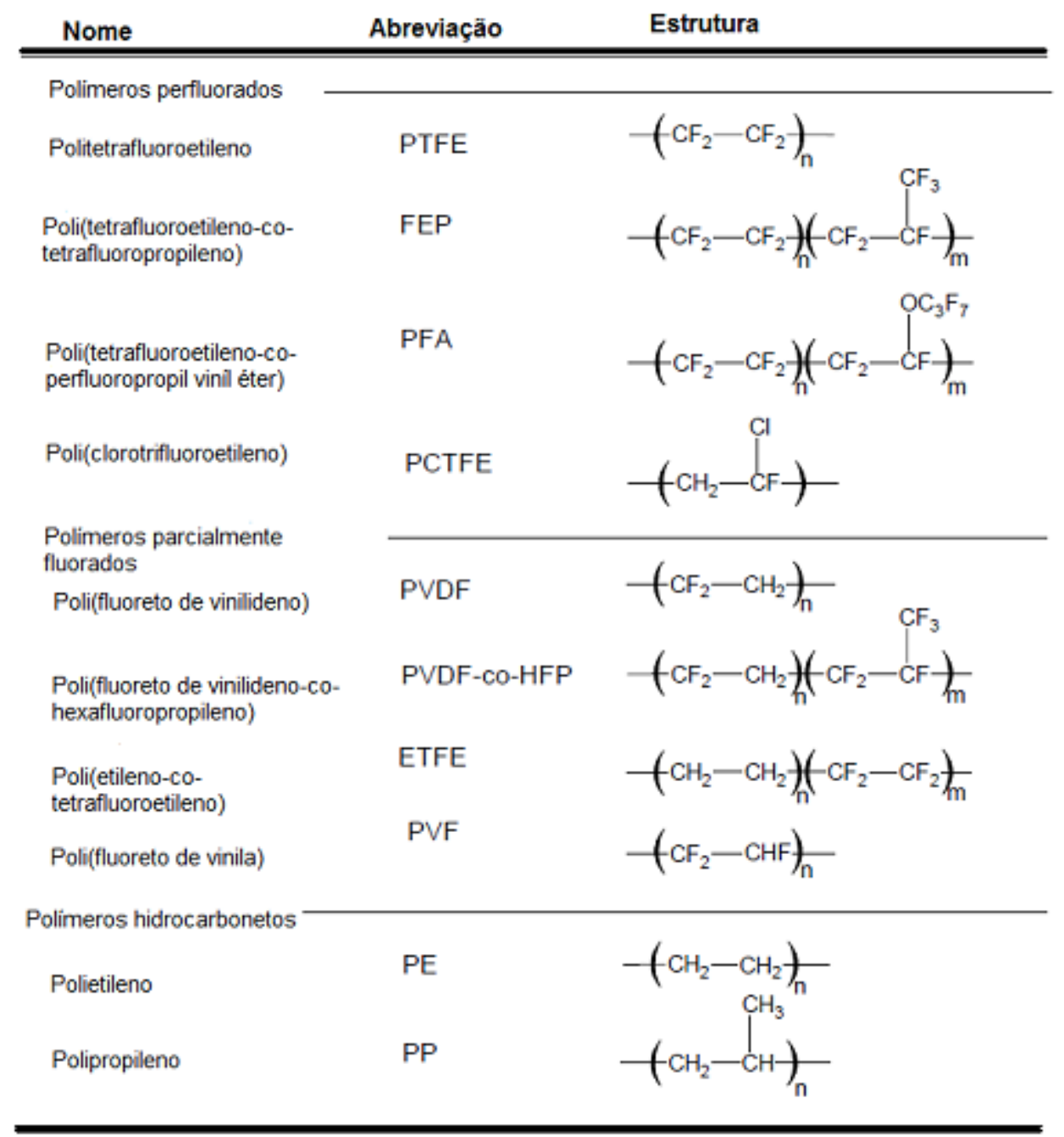

Fonte Adaptada de DARGAVILLE et al., 2003; GUBLER et al., 2005. 
Entre os polímeros constituídos de hidrocarbonetos, os filmes de polieteno (PE) e polipropileno (PP) são utilizados em vários tipos de membranas aniônicas devido à estrutura saturada, baixo custo, alta resistência a radiação, excelentes propriedades mecânicas, e estabilidade em meio eletroquímico severo (NASEF e HEGAZY, 2004). São considerados polímeros de funcionalização pelo processo de irradiação por pertencerem a categoria de polímeros reticuláveis, (NASEF e HEGAZY, 2004; GLUBER, 2014).

O polietileno (PE) é um polímero parcialmente cristalino, flexível, cujas propriedades são influenciadas pela quantidade relativa das fases amorfa e cristalina. Podem ser produzidos cinco tipos de diferentes de polietileno: polietileno de baixa densidade (LDPE). Polietileno de alta densidade (HDPE), polietileno linear de baixa densidade (LLDPE), polietileno de ultra alto peso molecular (UHMWPE) e polietileno de ultra baixa densidade (ULDPE) (COUTINHO et al., 2003).

Os fluoropolímeros possuem estabilidade química e física superior aos polímeros a base de hidrocarbonetos, devido à característica da ligação C-F. Além disso, estes polímeros também produzem radicais estáveis quando expostos à radiação. Os polímeros fluorados PTFE e PFEP têm demonstrado considerável resistência à radiação e produzem radicais estáveis com rendimentos de enxertia eficientes quando enxertados com diferentes monômeros (NASEF e HEGAZY, 2004).

Os fluoropolímeros parcialmente fluorados combinam estruturas hidrocarbônicas com fluorocarbônicas, como PETFE e PVDF, e são também excelentes polímeros para a preparação de membranas enxertadas pelo processo de irradiação. O PVDF é o único fluoropolímero que pode ser dissolvido em solventes comuns, tais como dimetil sulfóxido (DMSO) ou $\mathrm{N}$ metilpirrolidona (NMP), permitindo sua aplicação em vários segmentos. Outra característica do PVDF é a formação de dupla ligação devido à eliminação do fluoreto de hidrogênio (HF) após a irradiação. O PETFE, com estrutura alternada de PE e PTFE, confere propriedades únicas exatamente por combinar propriedades físico-químicas de ambos os polímeros hidrocarbonetos e fluorocarbonetos. Além de conferir excelente estabilidade térmica e superior resistência a solventes (NASEF e HEGAZY, 2004; GUBLER, 2014). 
$\mathrm{Na}$ variedade de polímeros perfluorados os polímeros PFA e PCTFE podem ser empregados na síntese de membranas aniônicas. O PFA possui propriedades semelhantes ao PTFE, excelente resistência a ambientes oxidantes e solventes orgânicos. A ampla presença de átomos de cloro na cadeia do PCTFE reduz a tendência à cristalização. Também possui excelente resistência a ambientes oxidantes e à radiação.

Uma representação simplificada das reações envolvidas no processo de enxertia por pré-irradiação, bem como a natureza do sitio ativo e a configuração dos enxertos formados é mostrada na FIG. 5. No caso da cisão de cadeia por irradiação, os sítios ativos são formados na extremidade dos fragmentos da cadeia. (GUBLER, 2014).

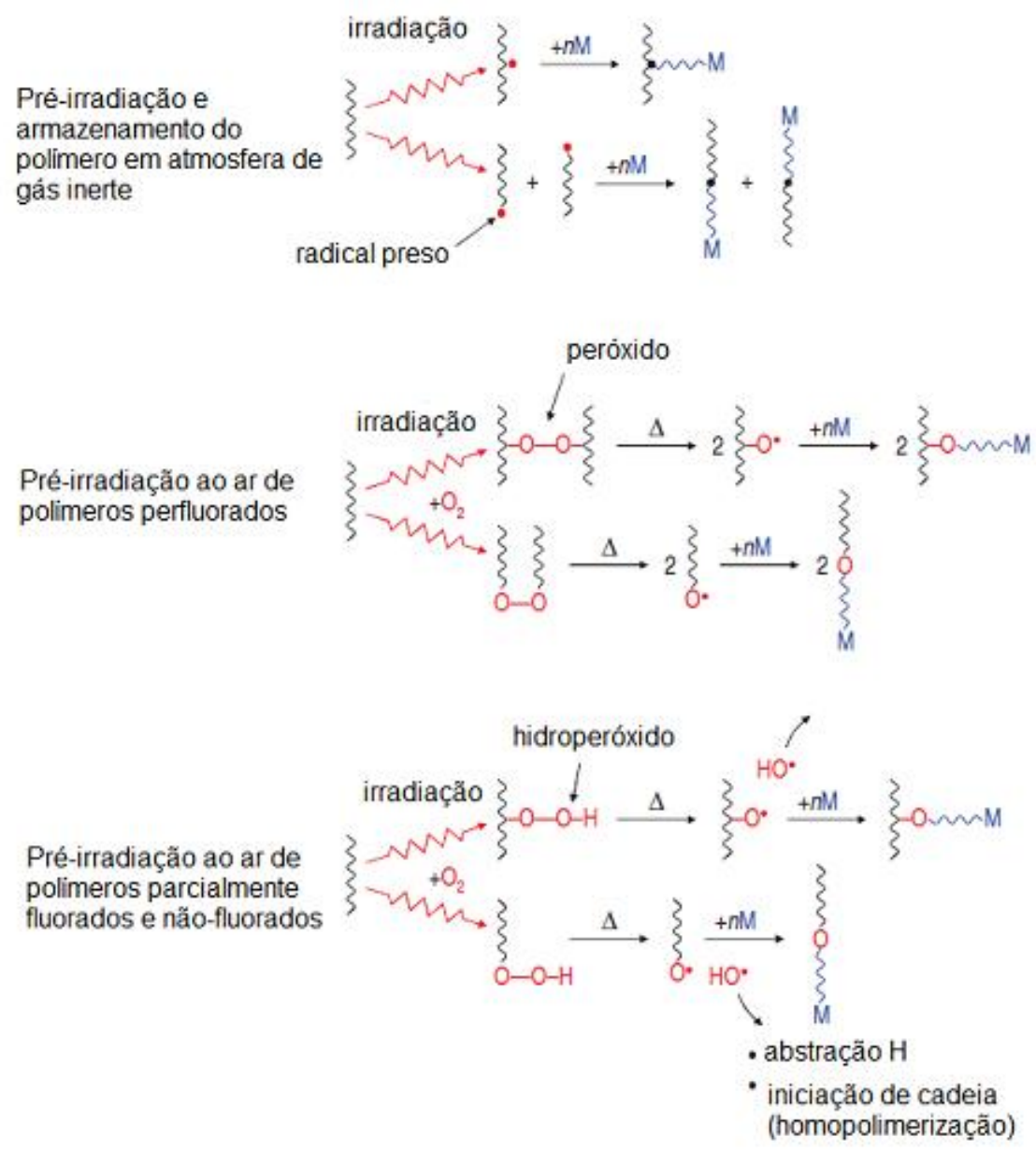

FIGURA 5 - Resumo das reações de enxertia utilizando o processo de pré-irradiação: formação de sítios ativos durante exposição à radiação; formação dos radicais (hidro)peróxidos no caso de reação na presença de ar, e iniciação da reação de copolimerização de enxerto (GUBLER, 2014). 
Segundo Gubler (2014) a tendência de reticulação e degradação por cisão de cadeia dos fluopolímeros sob a influência da radiação ionizante segue a seguinte ordem respectivamente:

$$
\begin{aligned}
& \text { PVF }>\text { PVDF }>\text { ETFE }>\text { FEP }>\text { PFA }>\text { PTFE } \\
& \text { PTFE }>\text { PFA }=\text { FEP }>\text { ETFE }>\text { PVDF }>\text { PVF }
\end{aligned}
$$

A degradação mecânica pode ser mitigada pelo uso de polímeros base e monômeros com ligações mais resistentes ao ataque de grupos $\mathrm{OH}^{-}$. Os polímeros fluorados apresentam maior resistência mecânica, contudo, são menos susceptíveis à formação de radicais durante a irradiação, o que pode resultar na formação de menor número de grupos funcionais disponíveis para o transporte de $\mathrm{OH}^{-}$e, consequentemente, em menor condutividade iônica. As etapas de preparação da membrana que envolve modificação química (enxertia, sulfonação, alquilação) e as condições de operação da célula a combustível alcalina, como temperatura e umidade podem afetar as propriedades mecânicas do polímero. (GUBLER, 2014).

Um dos grandes desafios no desenvolvimento de membranas alcalinas por enxertia pelo processo de irradiação é a sua baixa estabilidade química em soluções alcalinas concentradas. A instabilidade da membrana nas condições de operação contínua da célula em $\mathrm{pH}$ elevado $(\mathrm{pH}>14)$ e temperatura elevada $\left(>60^{\circ} \mathrm{C}\right.$ ) é uma das maiores causas de degradação química das membranas. $O$ aumento da temperatura de operação da célula pode desidratar a membrana tornando a degradação ainda mais severa (WANG et al., 2013).

A degradação da membrana pode ocorrer na cadeia do polímero base e nos grupos funcionais catiônicos, ambos estão diretamente relacionados com a condutividade iônica, propriedades mecânicas e estabilidade físico-química (WANG et al., 2013). 
Os polímeros fluorados são resistentes ao meio básico, entretanto em meio fortemente básico e temperaturas acima de $60 \stackrel{\circ}{\circ} \mathrm{C}$, a reação de dehidrofluorinização e o ataque hidroxílico podem causar a formação de duplas ligações $(C=C)$ (Eq. 20), e consequentemente a cisão da cadeia do polímero e redução das propriedades mecânicas da membrana (COUTURE et al., 2011; WANG et al., 2013):

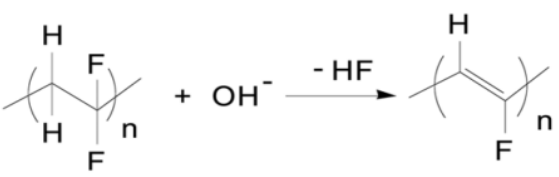

[Eq. 20]

Os mecanismos de degradação química de grupos aromáticos ocorrem, majoritariamente, via substituição nucleofílica direta de íons $\mathrm{OH}^{-}$nos grupos trocadores de anions, como mostrado na FIG. 6.

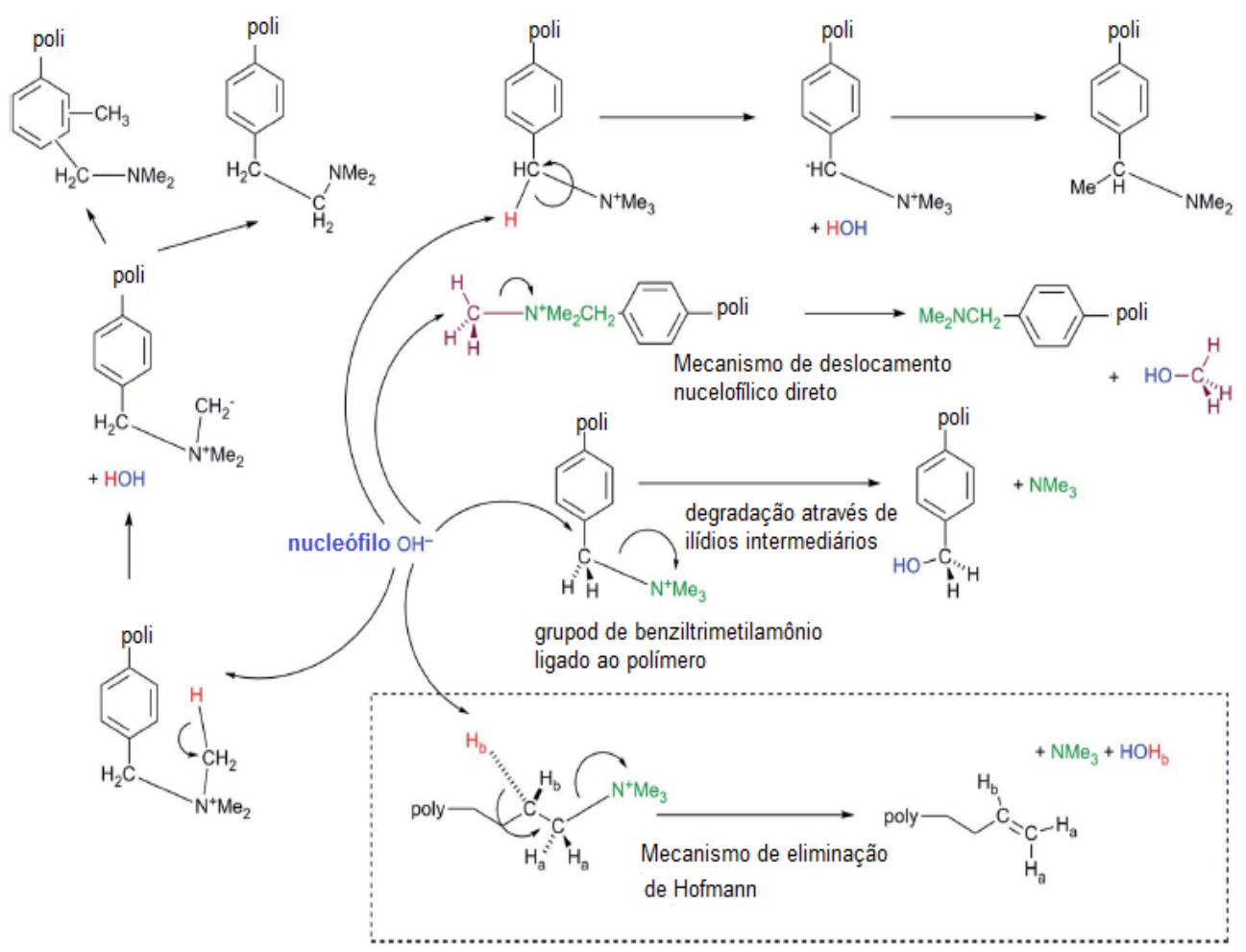

FIGURA 6 - Mecanismo de degradação da reação entre $\mathrm{OH}^{-}$e grupos trocadores de ânions (grupos catiônicos) baseados em benziltrimetilamônio. Adaptada de VARCOE et al., 2014. 
Para os grupos catiônicos baseados em alquilas, o mecanismo de degradação mais aceito é a eliminação de Hofmann. A eliminação de Hofmann decorre da reação entre os íons $\mathrm{OH}^{-}$e átomos de hidrogênio ligados ao carbono beta $(\beta-\mathrm{H})$, sobretudo, em alquilas de cadeia longa, que apresentam $\beta-\mathrm{H}$ na sua estrutura (VARCOE et al, 2014).

Diferentes tipos de aminas têm sido estudados visando à obtenção de membranas mais estáveis ao meio alcalino. A trimetilamina é amplamente utilizada na funcionalização de AEMs devido à facilidade e eficiência no processo de quaternização, embora seja susceptível a degradação por eliminação de Hofmann.

Estudos recentes sugeriram que grupos amônio contendo cadeia alquila longa sem carbono beta, como hexametileno-trimetilamônio (FIG. 6), ou com carbono beta "blindados" estericamente por grupos volumosos (cíclicos) podem inibir as reações de eliminação de Hofmann (VARCOE et al., 2014; CHENG et al., 2015).

Alternativas utilizando agentes de quaternização cíclicos como, diazobiciclo-octano (DABCO) com grupos $\beta$-Hs e uma estrutura cíclica com conformação antiperiplanar que ajudam a minimizar as reações de eliminação de Hofmann (FIG. 6), e o novo agente de quaternização bicíclico 1,5 diazobiciclo [4.3.0] noneno-5 (DBN) contendo cátions estáveis deslocalizados ao logo de duplas ligações que previnem a reação de degradação e a formação de ilídios intermediários (FIG 6) (VARCOE et al., 2014; CHENG et al., 2015).

AEMs contendo grupos $\mathrm{N}$-methylimidazolidina e $\mathrm{N}$-metilpirrolidona (MPY) exibiram maior estabilidade em álcali, mantendo a condutividade iônica mesmo após longos períodos de exposição em solução aquosa de $\mathrm{KOH}$ (CHENG et al., 2015; GONZALEZ et al, 2016 ).

A degradação térmica da membrana na célula alcalina pode ser ocasionada pela instabilidade térmica resultante da operação contínua em temperaturas elevadas e pelo aquecimento sob pressão durante o processo de preparação da MEA (ZHOU et. al, 2015). 


\subsection{Condutividade iônica}

As membranas aniônicas (AEM) apresentam, em geral, valores de condutividade iônica menores que as correspondentes membranas protônicas (PEM), como por exemplo, o Nafion ${ }^{\mathrm{TM}}$ (DuPont), que apresenta condutividade da ordem de $10^{-1} \mathrm{~S} \mathrm{~cm}^{-1}$, enquanto que as AEMs apresentam condutividade não superiores a $10^{-2} \mathrm{~S} \mathrm{~cm}^{-1}$. Essa diferença entre os valores de condutividade iônica se deve principalmente à menor mobilidade dos íons $\mathrm{OH}^{-}$quando comparado aos íons $\mathrm{H}^{+}$, e também aos baixos níveis de dissociação dos íons $\mathrm{OH}^{-}$ligados aos grupos catiônicos trocadores de ânions (MANLOUK e SCOTT, 2012; WANG et al., 2013; MAURYA et al., 2015).

A condutividade iônica das AEMs depende da concentração e mobilidade dos íons hidroxila presentes na membrana, as quais estão relacionadas às propriedades de transporte das membranas (MAURYA et al., 2015). É necessário entender e prever o transporte iônico e a condução da membrana em função da umidade relativa e das propriedades da membrana nas condições de operação, entretanto o endentimento do modelo de transporte para os ions hidroxila em AEMs ainda é limitado e baseiam-se nos mecanismos de transporte protônico das PEMs, incluindo mecanismo de Groutthuss, difusão de massa e migração, e processo convectivo (MERLE et al.; 2011;WANG et al., 2013; MAURYA et al., 2015).

A maioria dos íons hidroxilas é transportado através da membrana aniônica pelo mecanismo de Groutthuss. No mecanismo Grotthuss, os íons hidroxila são transportados por meio da transferência de protóns a partir das moléculas de água e se difundem por meio do hidrogênio ligado a molécula de água (MAURYA et al., 2015).

Na FIG. 7 é mostrado o mecanismo Grotthuss para o transporte do íon hidroxila em água. A temperatura de $25{ }^{\circ} \mathrm{C}$, o coeficiente de transporte dos íons hidroxila 


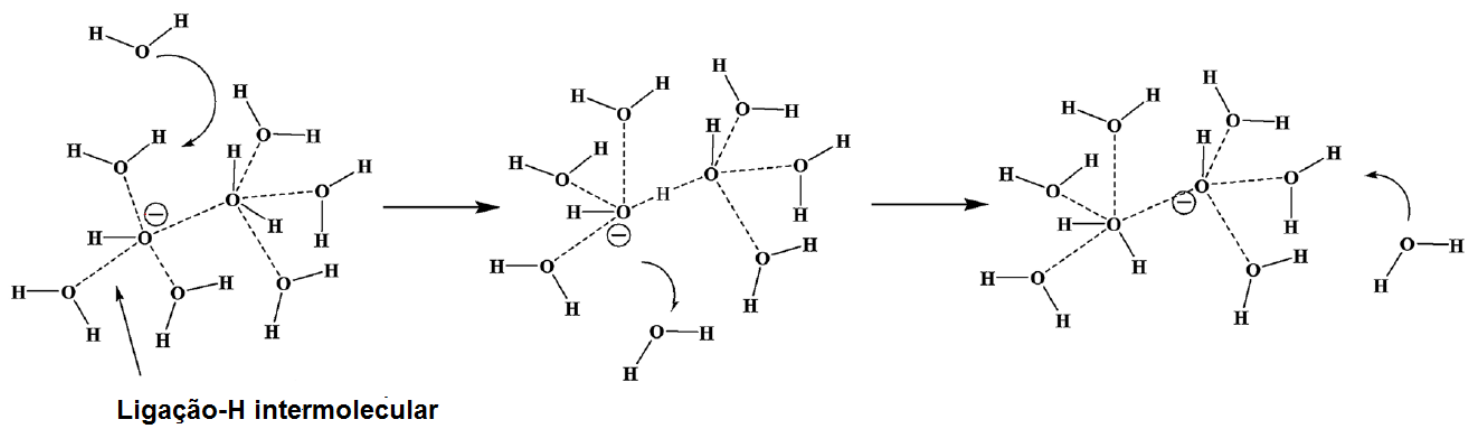

FIGURA 7 - Mecanismo Grotthuss para o transporte do íon hidroxila $\left(\mathrm{OH}^{-}\right)$em água (MAURYA et al., 2015).

A condutividade dos íons hidroxila é 1,7 vezes inferior a dos prótons na fase aquosa, pois, a $25^{\circ} \mathrm{C}$, o coeficiente de difusão dos prótons reportado $9,3 \mathrm{x}$ $10^{-9} \mathrm{~m}^{2} \mathrm{~s}^{-1}$ é superior aos íons hidroxila $5,3 \times 10^{-9} \mathrm{~m}^{2} \mathrm{~s}^{-1}$ na fase aquosa. Quando os coeficientes de transporte das membranas de Naffion ${ }^{\text {TM }} 115$ são comparados com os das membranas aniônicas sintetizadas com polímero totalmente fluorado PFEP e parcialmente fluorados PETFE, os valores são

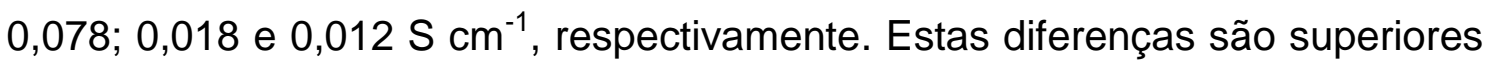
às diferenças para o transporte de massa. Entre as causas estão: a insuficiente dissociação e solvatação do grupo $\mathrm{OH}^{-}$, a morfologia da estrutura, o impacto da estrutura na inibição do mecanismo de transporte, interação do grupo $\mathrm{OH}^{-}$em solução e as cadeias laterais de amônio quaternário, e/ou a formação de carbonato/bicarbonato devido à presença de ar durante a medida (WANG et al., 2013; MAURYA et al., 2015).

Parte da baixa condutividade iônica das AEMs ocorre em função do baixo número de íons $\mathrm{OH}^{-}$resultante do baixo número de grupos catiônicos, como consequência do baixo grau de enxertia das cadeias laterais nos polímeros base e da estrutura química do grupo aniônico quaternário ligado ao enxerto (MAURYA et al., 2013; MANLOUK e SCOTT, 2012). A condutividade das AEMs pode ser melhorada com o aumento do IEC, entretanto pode causar um aumento excessivo da capacidade de absorção de água devido ao número excessivo número de moléculas de água em torno dos grupos de amônio. Excessivo IEC pode causar o intumecimento da membrana e degradação das propriedades químicas e mecânicas (MAURYA et al., 2015). 
O desenvolvimento de membranas de troca aniônica utilizando o processo de enxertia pelo método de irradiação tem sido investigado nos últimos anos na busca de membranas aniônicas mais eficientes e de menor custo. Esforços são realizados para explorar estruturas catiônicas novas e estáveis, projetando estruturas de cadeia fazendo uso do impedimento estérico, efeito eletrônico e também para melhorar a estabilidade alcalina da AEM. Outras estratégias envolvem preparação de membranas com morfologia favoráveis e a fixação de cátions não orgânicos na matriz polimérica para melhorar a condutividade iônica. Alguns desses avanços envolvendo a síntese de membranas aniônicas estão sumarizados a continuação.

Manlouk et al. (2012), reportaram uma série de estudos sobre a síntese de membranas aniônicas usando LDPE (40 a $50 \mu \mathrm{m})$, HDPE $(50 \mu \mathrm{m})$ e PETFE (25 $\mu \mathrm{m})$ como polímero base e VBC como monômero de enxertia. As membranas foram preparadas com filmes de PE pelo processo simultâneo de irradiação, usando radiação gama do ${ }^{60} \mathrm{Co}$, obtendo graus de enxertias de até $68 \%$, enquanto as membranas de PETFE irradiadas a $150 \mathrm{kGy}$ apresentaram grau de enxertia em meio aquoso de $24 \%$. A membrana de LDPE apresentou valores de condutividade de até $10^{-4} \mathrm{mS} \mathrm{cm}^{-1}$ a $70 \stackrel{\circ}{\circ} \mathrm{C}$ e potência máxima de até $48 \mathrm{~mW} \mathrm{~cm}^{-2}$ a $60 \stackrel{\circ}{\circ}$.

POYTON e VARCOE (2015), obtiveram densidade de potência de até 164 $\mathrm{mW} \mathrm{cm}{ }^{-2}$ com membranas de PETFE enxertadas em solução aquosa de propano-2-ol, e surfactante contendo $20 \%$ de VBC, v:v, e funcionalizadas com trimetilamina. Esta redução expressiva do teor do monômero VCB representa um avanço na síntese de membranas aniônicas considerando a toxidez do monômero VBC.

WANG et al. (2017), relataram que AEMs de PEFTE irradiados em doses absorvidas de radiação entre 30 e 40 kGy, e enxertadas em solução aquosa contendo 5\% de VBC apresentaram melhor distribuição de enxertia e maior estabilidade mecânica. Foram obtidas membranas AEMs com condutividade de até $68 \mathrm{~ms} \mathrm{~cm}^{-1}$ a $80 \stackrel{\circ}{\circ}$, e densidade de potencia de até $1160 \mathrm{~mW} \mathrm{~cm}^{-1}$.

FANG et al. (2012), utilizaram um processo alternativo na síntese de membranas de filmes pré-irradiados de PETFE enxertado com VBC buscando 
aumentar a estabilidade dos grupos quaternários de amônio. Realizaram a quaternização com grupo de amônio cíclico 1,4-diazobiciclo $(2,2,2)$ octano (DABCO) e polimerização com p-xilenodicloridro alquilado (DCX). A membrana intermediária foi novamente quaternizada com TMA. Obtiveram membranas estáveis e densidade de potência de $48 \mathrm{~mW} \mathrm{~cm}^{-2}$ após tratamento por até 120 horas a $60 \stackrel{\circ}{ } \mathrm{C}$ em solução de $\mathrm{KOH} 10 \mathrm{M}$.

SLADE et al. (2005) em seus estudos dedicaram atenção na preparação de membranas aniônicas por enxertia pelo processo de pré-irradiação utilizando filmes de PFEP, PVDF e PETFE como polímero base. O monômero de enxertia utilizado foi o VBC e funcionalizadas com trimetilamina. O filme de PVDF enxertado sofreu degradação na cadeia polimérica. As membranas dos filmes de PFEP apresentaram condutividade a $50{ }^{\circ} \mathrm{C}$ na forma $\mathrm{OH}^{-}$até $23 \mathrm{mS}$ $\mathrm{cm}^{-1}$ com graus de enxertia na ordem de $20 \%$.

FANG et al. (2012) utilizaram um processo alternativo na síntese de membranas de filmes pré-irradiados de PETFE enxertado com VBC buscando aumentar a estabilidade dos grupos quaternários de amônio. Realizaram a quaternização com grupo de amônio cíclico 1,4-diazobiciclo $(2,2,2)$ octano (DABCO) e polimerização com p-xilenodicloridro alquilado (DCX). A membrana intermediária foi novamente quaternizada com TMA. Obtiveram membranas estáveis e densidade de potência de $48 \mathrm{~mW} \mathrm{~cm}^{-2}$ após tratamento por até 120 horas a $60 \stackrel{\circ}{\circ}$ em solução de $\mathrm{KOH} 10 \mathrm{M}$.

ESPIRITU et al. (2017), inovaram ao estudar o efeito da degradação de membranas na forma $\mathrm{OH}^{-}$de filmes de LDPE e PETFE em água deionizada a temperatura ambiente no desempenho da célula, em geral este estudo é realizado em meio alcalino a altas temperaturas, e também identificaram os produtos formados na decomposição. Os autores concluíram que, a degradação das AEMs ocorreu devido à remoção do grupo funcional e a perda do anel aromático do monômero enxertado, no caso VBC. Observaram que taxas de dose de irradiação altas produziram membranas com maior estabilidade em termos de perda de IEC e melhor distribuição de enxertia do VBC. 


\section{MATERIAIS E MÉTODO}

\subsection{Materiais}

Para a síntese das membranas trocadoras de ânions (AEMs) foram utilizados filmes de polietileno de baixa densidade (LDPE), polietileno de ultra alto peso molecular (UHMWPE), poli (tetrafluoroetileno-co-hexafluoropropileno) (PFEP), e poli(etileno-co-tetrafluoroetileno) (PETFE), fornecidos pela Goodfellow Cambridge Limited (TAB. 4).

TABELA 4 - Filmes poliméricos utilizados na síntese das AEMs

\begin{tabular}{lcc}
\hline \multicolumn{1}{c}{ Nome } & Abreviação & $\begin{array}{c}\text { Espessura } \\
(\mu \mathrm{m})\end{array}$ \\
\hline Polietileno de baixa densidade & LDPE & 125 \\
Polietileno de ultra alto peso molecular & UHMWPE & 200 \\
Poli(etileno-co-tetrafluoroetileno) & PETFE & 125 \\
Poli(etileno-co-tetrafluoroetileno) & PFEP & 125 \\
\hline
\end{tabular}

Neste estudo os reagentes e solventes de grau analítico foram utilizados sem tratamento prévio (TAB. 5).

TABELA 5 - Reagentes e solventes utilizados na síntese das AEMs

\begin{tabular}{lcc}
\hline Nome & Pureza & Procedência \\
\hline Acetona & PA & Merck \\
Ácido clorosulfônico & PA, $97,0 \%$ & ProQuímicos \\
Ácido clorídrico & PA, $97,0 \%$ & R. Químicos \\
Álcool etílico & PA, $97,0 \%$ & ACS - Synth \\
Cloreto de sódio & PA, $99,0 \%$ & CAAL CasaAmericana \\
1,2 dicloroetano & PA, $99,5 \%$ & ACS - Synth \\
Hidróxido de potássio & PA, $99,5 \%$ & ACS - Synth \\
Hidróxido de sódio & PA, $97,0 \%$ & Labsynth \\
\hline
\end{tabular}


TABELA 5 - Continuação

\begin{tabular}{lcc}
\hline Nome & Pureza & Procedência \\
\hline Monômero de estireno & $99,5 \%$, inibidor-4-tert-butilcatecol & Sigma-Aldrich \\
Propano-2-ol & PA, $99,5 \%$ & ACS - Synth \\
Tolueno & PA, $88,5 \%$ & ACS - J.T. Baker \\
Trimetilamina & PA, $45 \%$ água & Sigma-Aldrich \\
Xileno & PA, $99,5 \%$ & ACS - J.T. Baker \\
\hline
\end{tabular}

\subsection{Síntese das membranas aniônicas}

As membranas aniônicas (AEMs) baseadas nos polímeros de polietileno de baixa densidade (LDPE), polietileno de ultra alto peso molecular (UHMWPE), poli(etileno-co-tetrafluoroetileno) (PETFE) e poli(tetrafluoroetilenoco-hexafluoroetileno) (PFEP) foram sintetizadas por enxertia com solução de monômero de estireno em diferentes concentrações via irradiação nos processos simultâneo e pré-irradiação utilizando raios gama de fontes de ${ }^{60} \mathrm{Co}$ e com feixe de elétrons de aceleradores de elétrons. As amostras foram préirradiadas com feixe de elétrons a temperatura ambiente na presença de $\mathrm{O}_{2}$, ou irradiadas no processo simultâneo em atmosfera de $\mathrm{N}_{2}$.

Após a enxertia, os filmes enxertados com monômero de estireno e limpos foram imersos em solução de ácido clorosulfônico em 1,2 dicloroetano $0,2^{\circ} \mathrm{M}$ para a adição de grupos funcionais sulfônicos $\left(\mathrm{SO}_{3} \mathrm{Cl}\right)$ à cadeia aromática do monômero de estireno.

A funcionalização com grupos quaternário de amônio foi realizada por imersão em solução de trimetilamina a 45 \% em água deionizada $\left(\mathrm{N}(\mathrm{Me})_{3}\right)$, v:v. Posteriormente, as membranas foram tratadas com HCl $1 \mathrm{molL}^{-1}$ para adição dos grupos $\mathrm{Cl}^{-}$, responsáveis pela troca iônica e estabilização dos grupos iônicos. Em seguida, foi realizada a reação de alquilação com $\mathrm{KOH} 1 \mathrm{molL}^{-1}$ para a adição dos grupos funcionais hidroxila (troca aniônica dos grupos $\mathrm{Cl}^{-}$por $\left(\mathrm{OH}^{-}\right)$. 
Entre as etapas também foram realizados tratamentos de limpeza e estabilização de $\mathrm{pH}$ ( $\mathrm{pH}$ neutro). O fluxograma do processo de síntese das membranas aniônicas encontra-se representado na FIG. 8.

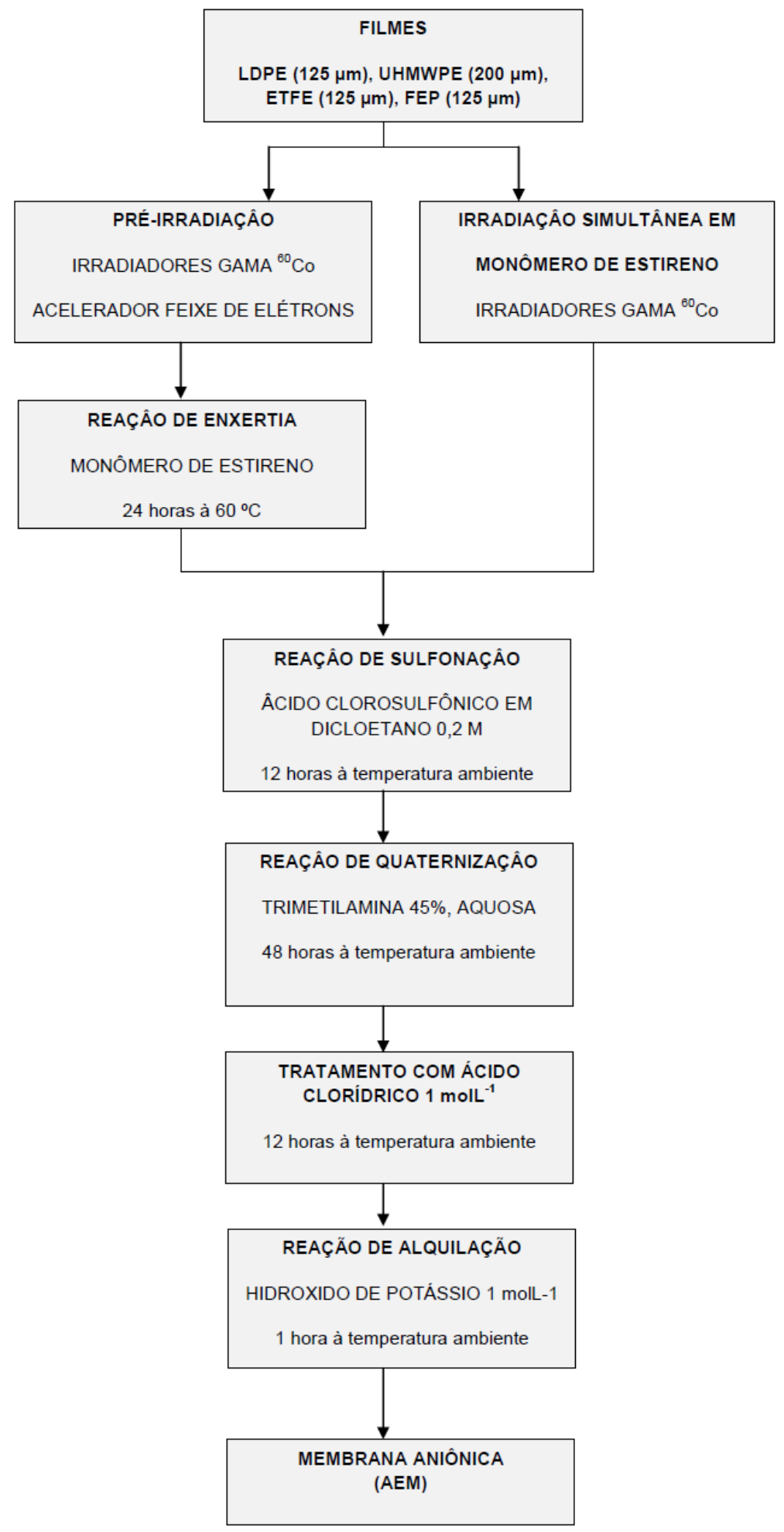

FIGURA 8 - Processo de síntese das membranas aniônicas (AEMs) 
As reações do processo de síntese estão mostradas na FIG. 9.
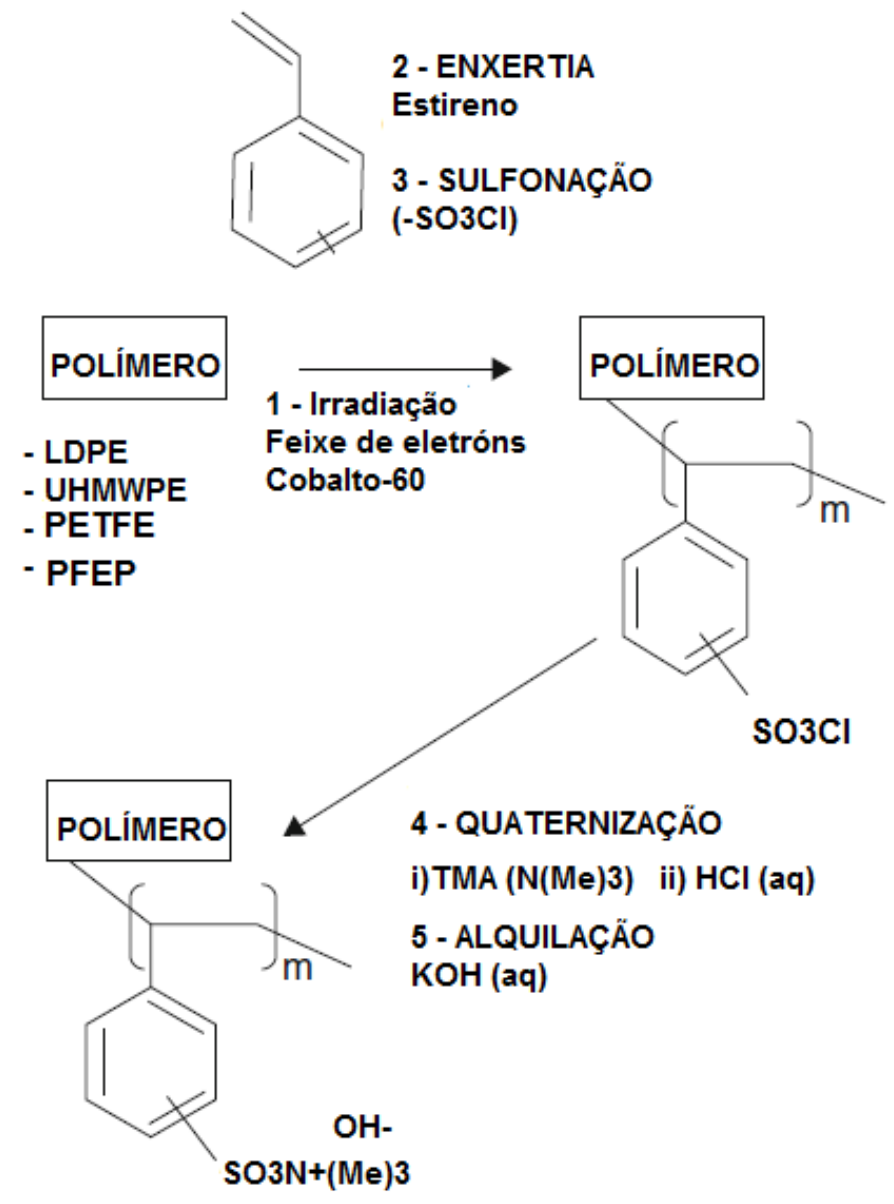

FIGURA 9 - Processo de síntese das membranas aniônicas de filmes de LDPE, UHMWPE, PETFE, PFEP enxertados por irradiação. Adaptada de (VARCOE e SLADE, 2006)

\subsubsection{Irradiação e enxertia dos polímeros}

A irradiação dos filmes de LDPE, UHMWPE, PETFE e PFEP foi realizada nos irradiadores Multipropósito de ${ }^{60} \mathrm{Co}$ e Gammacell 220, e no acelerador de elétrons Dynamitron JOB 188, do Centro de Tecnologia das Radiações (CTR) do IPEN - CNEN/SP nos processos simultâneo e de pré-irradiação. 


\subsubsection{Irradiador de ${ }^{60} \mathrm{Co}$ tipo Gammacell modelo 220}

O irradiador de ${ }^{60} \mathrm{Co}$ tipo Gammacell modelo 220 , Nordion (Canadá) foi classificado como irradiador de Categoria I pela Agência internacional de energia atômica (AIEA) e do Grupo 2 pela CNEN. A atividade inicial em 10/1987 era de 462,5 TBq (12500 Ci) e atualmente está com 35,34 TBq (955,17 Ci), em Janeiro/2017. É constituído de 35 lápis de Cobalto-60, dos tipos C-185 e 7810 (que são fontes seladas) que circundam internamente a câmara primária totalmente isolada. As fontes ficam dentro da blindagem, mesmo quando estão em operação. Não há geração de resíduos ou rejeitos radioativos. As amostras são acondicionadas na câmara de irradiação que possui dimensões limitadas com altura de $20 \mathrm{~cm}$, diâmetro de $15 \mathrm{~cm}$ e volume total de 3 litros (FIG. 10), que se desloca para a posição de irradiação.

Os parâmetros de irradiação das amostras utilizados foram: taxa de dose de 1,042 $\mathrm{kGyh}^{-1}$ e incerteza da taxa de dose de 2,75 \% (Janeiro de 2015).
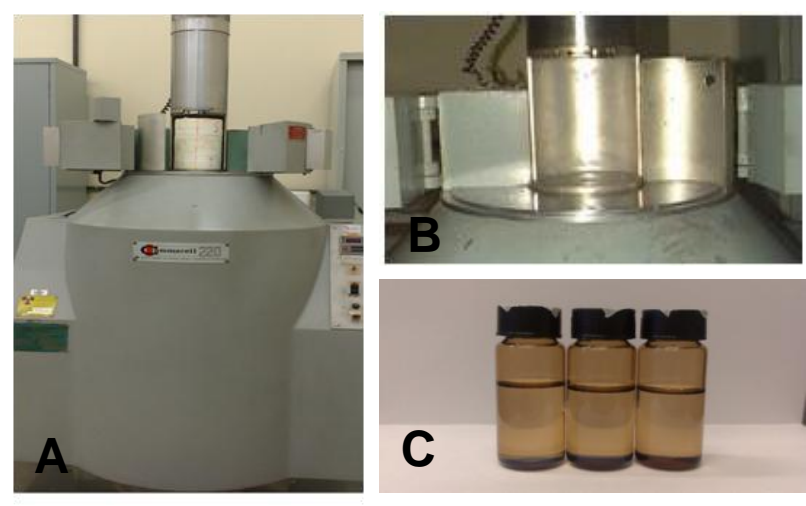

FIGURA 10 - Imagens: (A) e (B) Irradiador de ${ }^{60} \mathrm{Co}$ GammaCell modelo 220 do CTR do IPEN - CNEN/SP; e (C) amostras dos filmes de polímeros irradiados pelo processo simultâneo.

\subsubsection{Irradiador Multipropósito de ${ }^{60} \mathrm{Co}$}

O Irradiador Multipropósito de ${ }^{60} \mathrm{Co}$ do CTR/IPEN-CNEN/SP é classificado como irradiador de categoria IV pela AIEA e do Grupo 1 pela CNEN. Construído pelo IPEN, sua atividade radioativa é de 10,56 TBq $(285,3 \mathrm{kCi})$ em Junho de 2015 data da realização das irradiações. Possui como blindagens radioativas uma piscina de $7,0 \mathrm{~m}$ de profundidade e um buncker de concreto com paredes de 1,8 $\mathrm{m}$ de espessura. As fontes estão dispostas em módulos, 
que por sua vez são arranjados em duas estruturas denominadas racks. Comporta cerca de 504 fontes seladas de ${ }^{60} \mathrm{Co}$ (lápis de ${ }^{60} \mathrm{Co}$ ), contando atualmente com 52. A capacidade total da câmara de irradiação é de $8 \mathrm{~m}^{3}$ para irradiações estacionárias ou 16 containers de $270 \mathrm{~L}$ para irradiações em modo contínuo (FIG 11).

A medição da dose absorvida pelos produtos é feita por meio do uso de dosímetros de poli(metacrilato de metila) (PMMA).

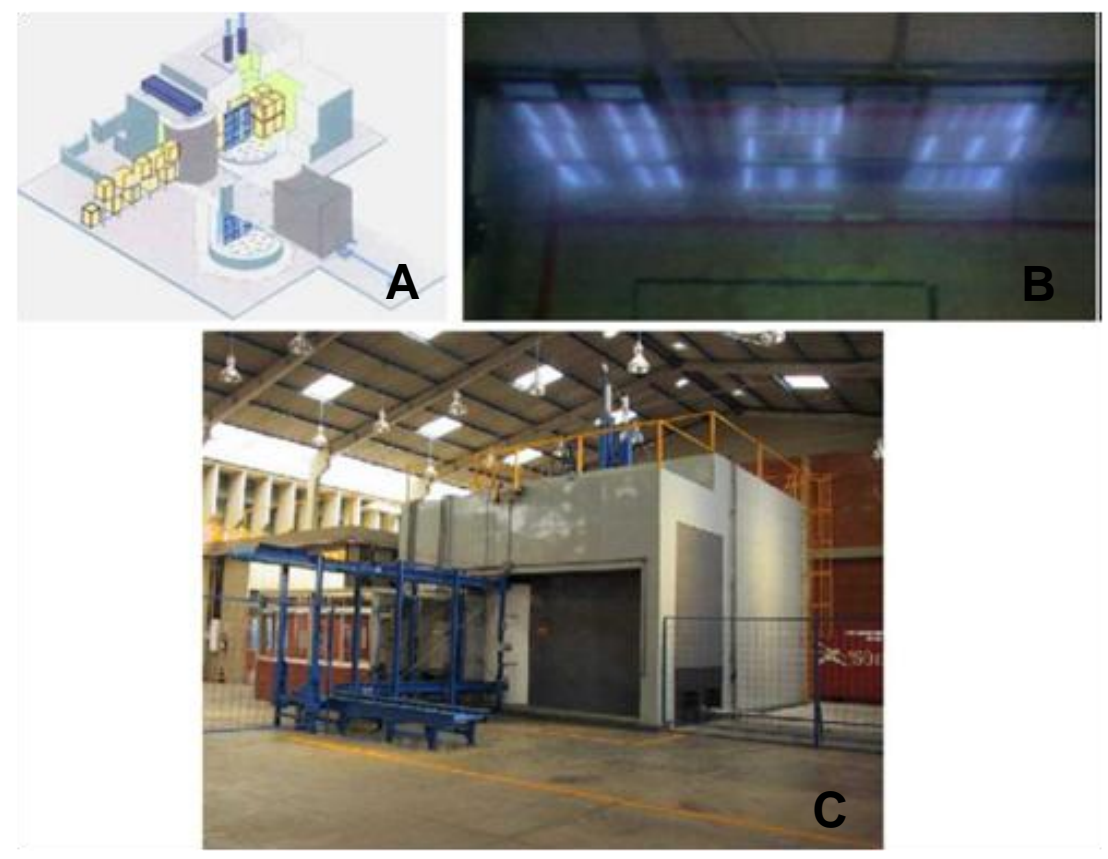

FIGURA 11 - Imagens: Irradiador Multipropósito de ${ }^{60}$ Co do CTR/IPEN-CNEN/SP. (A) Esquema panorâmico do irradiador Multipropósito de ${ }^{60} \mathrm{Co}$, (B) Fontes de ${ }^{60} \mathrm{Co}$ distribuídas nos racks no interior da piscina, (C) Vista externa do Irradiador Multipropósito de ${ }^{60} \mathrm{Co}$.

Os dosímetros de rotina de PMMA com corantes utilizados foram os fabricados pela Harwell Dosimeters Ltd. Os modelos, com as respectivas incertezas, são mostrados na TAB. 6. 
TABELA 6 - Dosímetros de rotina de PMMA com corantes fabricados pela Harwell Dosimeters Ltd.

\begin{tabular}{ccc}
\hline Dosímetro & Faixa de medição (kGy) & Incerteza da medida \\
\hline Amber 3042 & 1 a 30 & $2,0 \%$ \\
Red 4034 & 5 a 50 & $2,5 \%$ \\
\hline
\end{tabular}

\subsubsection{Acelerador de elétrons DC 1500/25/4 - JOB 188}

O Acelerador de elétrons DC 1500/25/4 - JOB 188, tipo Dynamitron ${ }^{\circledR}$, fabricado pela RDI - Radiation Dynamics Inc. atualmente adquirida pela IBA Industrial S.A. Esse equipamento só produz radiação ionizante quando energizado. Suas características são: modelo DC 1500/25/4; energia máxima de 1,5 MeV; corrente de feixe de 25 mA; varredura de 48" (1,20 m); potência de máquina de $150 \mathrm{~kW}$; potência máxima de feixe de $37,5 \mathrm{~kW}$; taxa de dose mínima de 1,07 kGy.s ${ }^{-1}$ e taxa de dose máxima 161,67 kGy.s ${ }^{-1}$ (FIG 12).
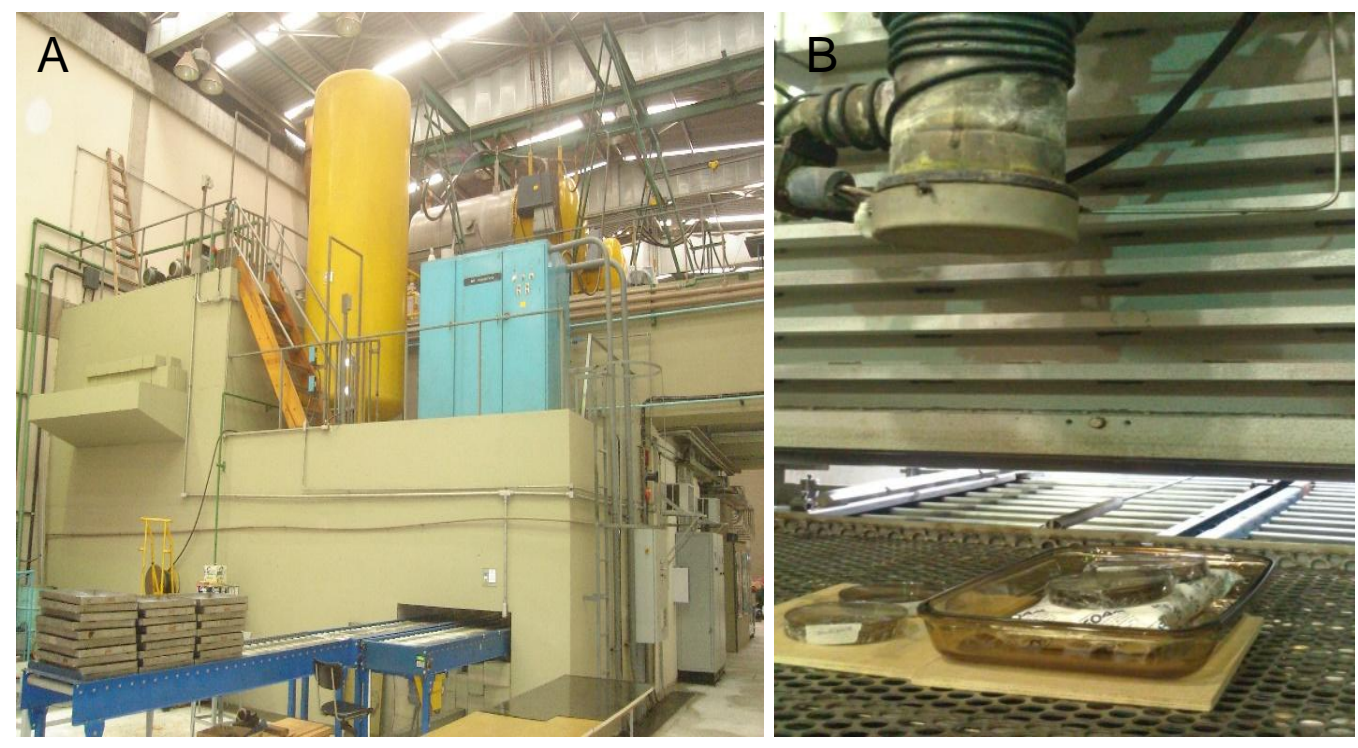

FIGURA 12 - Imagens: (A) Acelerador de elétrons JOB 188 tipo Dynamitron do CTR/IPEN-CNEN/SP, (B) amostras de filmes pré-irradiados.

Os parâmetros de processo utilizados nos experimentos foram: dose total por passada $5 \mathrm{kGy}$, densidade do material de $1,7 \mathrm{~g} . \mathrm{cm}^{-3}$, espessura $0,3 \mathrm{~mm}$, energia 0,549 MeV, HVD 35,10 mA, largura do feixe $100 \mathrm{~cm}$, scan 42,7\%, 
corrente de feixe 3,21 mA, velocidade da bandeja 6,72 $\mathrm{m}_{\mathrm{min}} \mathrm{mi}^{-1}$ e taxa de dose 22,39 kGy.s ${ }^{-1}$. O número de passadas foi definido em função da densidade e espessura da amostra, e dose total a ser aplicada.

\subsubsection{Preparação das amostras}

Filmes dos polímeros LDPE, UHMWPE, PETFE e PFEP foram cortados nas dimensões de $3,0 \mathrm{~cm} \times 5,0 \mathrm{~cm}$. O tratamento de limpeza dos filmes de foi realizado com os solventes: acetona e imersão em álcool etílico (temperatura ambiente, por 1 hora), para a remoção das impurezas residuais de processo. Os filmes foram secos em estufa a $60 \stackrel{\circ}{\circ}$ por 1 hora e posteriormente pesados.

No processo de pré-irradiação, os filmes de LDPE, UHMWPE, PETFE e PFEP, previamente limpos e pesados, foram dispostos em placa de Petri recoberta com filme de PVC e irradiados no acelerador de elétrons Dynamitron JOB $188(E=1,5 \mathrm{MeV}$ e corrente de feixe 3,21 mA) nas doses de 20, 40, 70, 80 e 100 kGy com taxa de dose de 22,39 kGy s$^{-1}$.

As amostras filmes dos polímeros pré-irradiados LDPE, UHMWPE, PETFE e PFEP pré-irradiadas foram mantidas em freezer à temperatura de -70 $\pm 4 \stackrel{\circ}{ } \mathrm{C}$, por até 10 meses para minimizar o decaimento dos radicais que haviam sido formados após a irradiação até a realização da etapa de enxertia e do estudo do decaimento dos radicais em função do tempo. Segundo NASEF e HEGAZY (2004), VARCOE et al. (2007), KIZEWSKI et al. (2013), POYTON e VARCOE (2015) o armazenamento a baixas temperaturas (-36 으 $-80 \mathrm{C}$ ) se mostrou adequado para a retenção dos radicais formados durante a irradiação por até 12 meses. A estabilidade dos radicais foi acompanhada por medidas de espectroscopia de ressonância paramagnética eletrônica (EPR).

Neste caso, a enxertia foi realizada sob atmosfera inerte de nitrogênio $\left(\mathrm{N}_{2}\right)$ por imersão das amostras em frascos de vidro contendo as soluções de monômero de estireno nas seguintes relações em volume (v:v): i) estireno:tolueno (60:40), ii) estireno:propano-2-ol (60:40) e iii) estireno:tolueno $(20: 80)$ sob atmosfera inerte de nitrogênio $\left(\mathrm{N}_{2}\right)$ durante 24 horas a $60 \stackrel{\circ}{\mathrm{C}}$ (KIZEWSKI et al., 2013) 
No processo simultâneo de irradiação, os frascos de vidro contendo os filmes de LDPE, UHMWPE, PETFE e PFEP $(3,0 \mathrm{~cm} \times 5,0 \mathrm{~cm})$, limpos e previamente pesados ( $m_{0}$, massa antes da enxertia), foram completados com a solução de monômero de estireno nas seguintes relações em volume (v:v): i) estireno:tolueno (60:40), ii) estireno:propano-2-ol (60:40) e iii) estireno:tolueno $(20: 80)$. Essas soluções foram mantidas em atmosfera de nitrogênio $\left(N_{2}\right)$ por 15 minutos e, em seguida, os fracos foram fechados e selados, e irradiados nos irradiadores de ${ }^{60} \mathrm{Co}$ Gammacell 220 (taxa de dose 1,042 $\mathrm{kGyh}^{-1}$ ) e Multipropósito (taxa de dose entre 8 e $11 \mathrm{kGyh}^{-1}$ ), a temperatura ambiente nas doses de 20, 40, 60, 80 e 100 kGy. O método adotado para o processo de simultâneo de irradiação foi adaptado de MANLOUK e SCOTT (2012).

As amostras foram irradiadas nos diferentes irradiadores de ${ }^{60} \mathrm{Co}$ para avaliar a influência dos parâmetros de processo de irradiação (tempo, taxa de dose, dose total) no grau e distribuição da enxertia nos filmes dos polímeros PETFE e PFEP.

O tratamento de limpeza dos filmes enxertados foi realizado com o solvente xilol, por 30 minutos no aparelho ultrassônico, seguido de imersão em xilol por 12 horas a temperatura ambiente para a remoção de homopolímeros e eventuais impurezas resultantes da reação. Os filmes foram secos a $60{ }^{\circ} \mathrm{C}$ até massa constante ( $m_{g}$, massa após enxertia) para a determinação do grau de enxertia (DOG). Os testes foram realizados em duplicata.

\subsubsection{Reação de sulfonação dos polímeros enxertados}

A reação de sulfonação foi realizada por imersão dos filmes enxertados em solução de ácido clorossulfônico em dicloroetano $0,2 \mathrm{M}$ por 12 horas a temperatura ambiente (FIG. 13). 
$\mathrm{O}$ ácido clorossulfônico introduz os grupos sulfônicos $\left(-\mathrm{SO}_{3} \mathrm{H}\right.$ ou $\left.\mathrm{Cl}\right)$ nos grupamentos do monômero de estireno dos filmes enxertados. Este procedimento foi adaptado de SHERAZI et al. (2009); WALSBY et al. (2001).

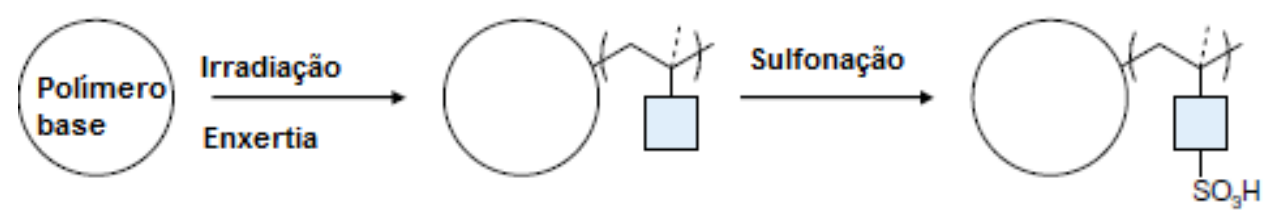

FIGURA 13 - Reação de sulfonação. Adaptada de GUBLER (2014)

Após a reação de sulfonação, as membranas foram lavadas com água deionizada até $\mathrm{pH}$ neutro para a remoção de ácido residual e armazenadas em água deionizada para posterior determinação do índice de troca iônica (IEC) e capacidade de absorção de água (WU).

\subsubsection{Reação de quaternização}

As amostras das membranas sulfonadas foram funcionalizadas por imersão em solução aquosa de trimetilamina, $45 \%$ em água (v:v), por 48 horas a temperatura ambiente para a introdução dos grupos quaternário de amônio. Em seguida, as membranas foram lavadas com água deionizada a $50{ }^{\circ} \mathrm{C}$ até pH neutro para remoção do excesso de amina.

As membranas obtidas foram tratadas em solução de ácido clorídrico $1 \mathrm{molL}^{-1}$ por 12 horas a temperatura ambiente, para transformar a membrana na forma de cloreto $\left(-(\mathrm{CH} 3)_{3} \mathrm{~N}^{+} \mathrm{Cl}\right)$. As membranas foram então lavadas com água deionizada a $50{ }^{\circ} \mathrm{C}$ até $\mathrm{pH}$ neutro para remoção do excesso de ácido e mantidas a temperatura ambiente em frascos contendo água deionizada conforme descrito por LIU et al. (2011). 


\subsubsection{Reação de alquilação}

A conversão das membranas na forma hidroxila foi executada imediatamente antes da realização das análises e testes por imersão da membrana na forma cloreto em solução aquosa de hidróxido de potássio $1 \mathrm{~mol} \mathrm{~L}^{-1}$ a temperatura ambiente por uma hora. Foram realizadas duas trocas de solução durante este período para obter uma troca iônica eficiente.

As membranas quaternizadas (na forma $\mathrm{OH}^{-}$) foram lavadas com água deionizada a $50 \stackrel{\circ}{\circ}$ em atmosfera de nitrogênio até $\mathrm{pH}$ neutro. A água deionizada em atmosfera de nitrogênio foi utilizada para minimizar a formação de íons carbonato resultante da reação com dióxido de carbono proveniente do ar (POYNTON e VARCOE, 2015).

\subsection{Caracterização das membranas aniônicas}

\subsubsection{Determinação do grau de enxertia (DOG)}

O grau de enxertia (DOG), que representa a proporção do polímero enxertado na membrana, foi calculado utilizando-se a Eq. 20 (MANLOUK e SCOTT, 2012):

$$
\operatorname{DOG}(\%)=\frac{m_{g}-m_{0}}{m_{0}} \times 100
$$

sendo, $m_{0}$ e $m_{g}$ as massas da membrana antes e após a enxertia.

Para as medições de massa foi utilizada uma balança analítica Shimadzu AUW220D com precisão de 0,00001 g.

\subsubsection{Determinação da capacidade de troca iônica das membranas sulfonadas}

A capacidade de troca iônica (IEC) da membrana sulfonada foi determinada pelo método de titulação indireta. Uma amostra de membrana seca $(M)$ foi mantida em uma solução de cloreto de sódio $3 \mathrm{~mol} \mathrm{~L}^{-1}(25 \mathrm{~mL}$, 
$\mathrm{V}_{\mathrm{NaCl}}$, a temperatura ambiente, durante 24 horas. Uma alíquota de $10 \mathrm{~mL}$ de solução foi então titulada com solução aquosa de hidróxido de sódio $0,01 \mathrm{~mol}$ $\mathrm{L}^{-1}\left(\mathrm{~V}_{\mathrm{NOH}}\right.$, gasto). O IEC ( mmolg $^{-1}$ ) foi calculado conforme a Eq. 21 (SHERAZI et al., 2009):

$$
\text { IEC }\left(\text { mmolg }^{-1}\right)=\frac{\left(0,01 * V_{\text {NaOH }} * n\right)}{M}
$$

sendo, $\mathrm{V}_{\mathrm{NaOH}}(\mathrm{mL})$ volume de solução aquosa de hidróxido de sódio $0,01 \mathrm{~mol} \mathrm{~L}^{-1}$ gasto na titulação, $n$ é a relação entre alíquota titulada e o volume total da solução, e $\mathrm{M}$ a massa seca da membrana previamente pesada.

\subsubsection{Determinação da capacidade de absorção de água}

Para determinar a capacidade de absorção de água (WU) a membrana foi imersa em água deionizada e mantida a temperatura ambiente por $24 \mathrm{~h}$. Em seguida, a membrana foi removida da água e pesada imediatamente após a remoção do excesso de água de sua superfície com papel de filtro. A membrana então foi seca em estufa a vácuo a $60 \stackrel{\circ}{ } \mathrm{C}$ e pesada até a obtenção de massa constante. O WU foi calculado usando a Eq. 22 (LIU et al., 2011; LI et al., 2010):

$$
W U(\%)=\frac{\left(m_{h}-m_{d}\right)}{m_{d}} \times 100
$$

sendo, $m_{h}$ a massa da membrana umidificada e $m_{d}$ a massa da membrana após secagem (massa seca).

O número médio de moléculas de água por grupos funcionais (sítio de troca aniônica $\left.\left(-\mathrm{NMe}^{+3}\right)\right), \lambda$, foi calculado usando a Eq. 23 :

$$
\lambda=\frac{W U}{\operatorname{IEC} \times 100 \times 18,01}
$$

sendo, IEC a capacidade de troca iônica, $18,01 \mathrm{~g} \mathrm{~mol}^{-1}$ a massa molar da água, WU o conteúdo de água da membrana. 


\subsubsection{Determinação da capacidade de troca iônica}

A capacidade de troca iônica (IEC) da membrana alcalina foi determinada pelo método de titulação indireta. Uma amostra da membrana seca (M) foi mantida em solução de ácido clorídrico $0,1 \mathrm{molL}^{-1}\left(25 \mathrm{ml}, \mathrm{V}_{\mathrm{HCl}}\right)$ a temperatura ambiente durante 12 horas. Esta solução foi titulada com solução aquosa de hidróxido de sódio $0,01 \mathrm{molL}^{-1}$ ( $\mathrm{V}_{\mathrm{NaOH}}$, gasto). O IEC foi determinado conforme a Eq. 24 (FANG et al., 2012):

$$
\operatorname{IEC}\left(\mathrm{mmolg}^{-1}\right)=\frac{\left(V_{\mathrm{HCl}} \times C_{1}-V_{\mathrm{NaOH}} \times C_{2}\right)}{M}
$$

sendo $C_{1}$ e $C_{2}$ as concentrações das soluções de $\mathrm{HCl}$ e $\mathrm{NaOH}$, respectivamente, e $M$ a massa da membrana após secagem.

\subsubsection{Espectroscopia de ressonância paramagnética eletrônica (EPR)}

A irradiação dos polímeros de LDPE, UHMWPE, PETFE e PFEP promoveu a formação de radicais livres que são responsáveis pelas reações de enxertia, portanto, para entender o mecanismo de reação desses sistemas é necessário conhecer os tipos de radicais formados, bem como a variação de sua concentração com o tempo, comportamento do decaimento dos radicais, tempo de vida e estabilidade.

Neste trabalho, a técnica de espectroscopia de ressonância paramagnética eletrônica (EPR) foi utilizada para identificar o tipo de radicais formados, bem como o tempo de vida, o decaimento e a estabilidade dos radicais formados durante o processo de pré-irradiação dos polímeros base e armazenados a baixa temperatura $(-70 \pm 4 \stackrel{\circ}{\circ})$.

A espectroscopia de ressonância paramagnética eletrônica (EPR, do inglês electron paramagnetic resonance) é uma técnica não destrutiva apropriada para caracterizar e monitorar espécies paramagnéticas dentre elas elétrons desemparelhados, ou seja, os radicais livres. Outra vantagem desta técnica é a obtenção de informações sobre a estrutura eletrônica por meio do cálculo do $g$ (fator giromagnético). Esta técnica se baseia em transições 
induzidas por uma fonte de microondas de frequência $v$, entre os subníveis de spin de átomos sujeitos a um campo magnético externo estático (Efeito Zeeman). (SPINKS e WOODS, 1990; BRUSTOLON e GIAMELLO, 2009).

As medições são feitas submetendo o material paramagnético em um campo magnético (BRUSTOLON e GIAMELLO, 2009) de intensidade $B_{0}$, fazendo com que o elétron desemparelhado possa tomar as orientações paralela e antiparalela ao sentido do campo magnético aplicado de acordo com a energia de micro-ondas recebida pela amostra. A orientação paralela encontra-se em um estado de menor energia (efeito Zeeman), sendo a diferença de energia entre os dois estados, $\Delta E$, dada pela equação básica da espectroscopia por EPR derivada do efeito Zeeman (Eq. 25) (SPINKS e WOODS, 1990; BRUSTOLON e GIAMELLO, 2009):

$$
\Delta E=h \cdot v=g \cdot \mu_{B} \cdot B_{0}
$$

sendo, $h$ constante de Plank $\left(6,626 \cdot 10^{-34} \mathrm{~J} . \mathrm{s}\right)^{*} ; v$ frequência de micro-ondas $(\mathrm{Hz}) ; g$ razão giromagnética; $\mu B$ Magneton de Bohr $\left(9,274.10^{-24} \mathrm{~J}^{-\mathrm{T}^{-1}}\right) ; B_{0}$ campo magnético $(\mathrm{T})$.

Como as condições dos picos de ressonância dependem das estruturas eletrônicas e moleculares de cada radical é conveniente expressar também em termos de $g$. É possível pelo valor do $g$, por exemplo, diferenciar as espécies paramagnéticas orgânicas das inorgânicas (WEIL e BOLTON, 2007). O campo magnético local pode ser induzido pelo movimento orbital do elétron desemparelhado (WEI e BOLTON, 2007). Quando colocado em um campo magnético externo de intensidade $B_{0}$, frequência variada $(0)$ e demais parâmetros constantes, o valor $g$ pode ser estimado pela Eq. 26 (MITOV et al., 2006; LARSEN et al., 2010):

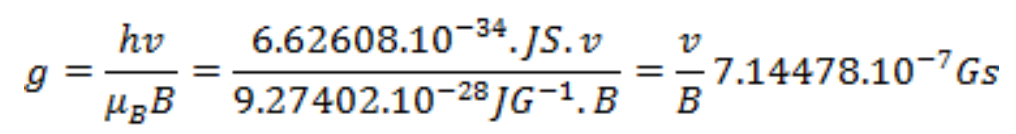


Rearranjando a Eq. 26 em termos de $g$ e utilizando as unidades adequadas, teremos a Eq. 27:

$$
g=714,4775 \frac{\mathrm{v}(\mathrm{em} \mathrm{GHz})}{B_{0}(\mathrm{em} G)}
$$

Os sinais de EPR podem ser gerados por medições de absorção de energia feitas em diferentes valores de campo magnético $B_{0}$, mantendo a frequência de micro-ondas constante. $O$ espectro resultante é a primeira derivada do sinal de absorção e é normalmente representado em termos de intensidade do campo magnético no eixo das abscissas (eixo $\mathrm{x}$ ) e a intensidade resultante no eixo das ordenadas (eixo y).

Outros parâmetros importantes utilizados para avaliação neste trabalho foram: i) intensidade do sinal de EPR, utilizada na comparação das linhas derivadas nos espectros e no decaimento do sinal. A intensidade do sinal de EPR obtida pela medida pico-a-pico das linhas derivadas do espectro; ii) o fator g., obtido a partir da Eq. 27, foi utilizado para caracterizar a posição de ressonância e identificar os sinais obtidos.

As medidas das amostras dos filmes pré-irradiados dos polímeros de PETFE, PFEP, LDPE, UHMWPE $(2,5 \mathrm{~cm} \times 3,0 \mathrm{~cm})$ mantidas a baixa temperatura $(-70 \pm 4 \stackrel{\circ}{\circ})$ foram realizadas em equipamento Bruker EMX plus a temperatura ambiente, operando na banda $X$, com frequência de micro-ondas na região de $9,86 \mathrm{GHz}$, potência de microondas de $20 \mathrm{~mW}$, amplitude de modulação de $1 \mathrm{G}$ e campo magnético entre 330 e $370 \mathrm{mT}$. As medidas foram realizadas com as amostras na forma de filme, sem tratamento, em tubos de quartzo.

\subsubsection{Espectroscopia Raman}

Os espectros Raman foram obtidos no equipamento Raman Dispersivo Xplora da Horiba Scientific.com laser $532 \mathrm{~nm}$ no intervalo de 400 a $2000 \mathrm{~cm}^{-1}$. 
As amostras dos filmes e membranas foram secos a temperatura ambiente em estufa à vácuo durante 30 minutos.

\subsubsection{Microscopia eletrônica de varredura (MEV)}

As amostras foram analisadas em Microscópio Eletrônico de Varredura, MEV, marca JEOL, modelo JSM- 6010LA.

As amostras dos filmes e membranas na forma hidroxila $\left(\mathrm{OH}^{-}\right)$foram secos a temperatura ambiente em estufa à vácuo durante 30 minutos e recobertas com ouro (tempo de recobrimento $1 \mathrm{~min}$ ).

\subsubsection{Microscopia de força atômica usando modo de operação de força máxima QNM}

A técnica de microscopia de força atômica (AFM) foi utilizada para avaliar a morfologia e as propriedades mecânicas dos polímeros, distribuição da enxertia no polímero, rugosidade e módulo elástico.

A análise de microscopia de força atômica (AFM) foi realizada a temperatura ambiente utilizando Brucker Multimode 8 operando no modo QNM, scanner E, scansize $5 \mu \mathrm{m}, 256 \times 256$ pontos. A calibração foi realizada com safira, sensitive $30,12 \mathrm{~nm} / \mathrm{V}$, constante elástica do cantilever $(\mathrm{K})$ 0,3 N/m.

O modo de operação QNM gera um mapeamento das propriedades da superfície e da topografia da amostra. O modo opera em contato intermitente, utilizando uma sonda de constante elástica adequada ao material em análise.

Neste modo são geradas, em uma única varredura, cinco imagens - uma da morfologia e as demais como mapeamentos de módulo elástico, adesão, dissipação de energia e deformação para uma força conhecida.

A topografia da superfície é gerada pela manutenção da força máxima constante (PeakForce) entre a ponta e a amostra. O mapeamento das propriedades mecânicas da superfície foi obtido pelo gráfico da força em 
função da distância entre a ponta e a amostra (FIG. 14) (MEYER et al., 1965; BONNELL, 1993; PITTENGER, 2012).

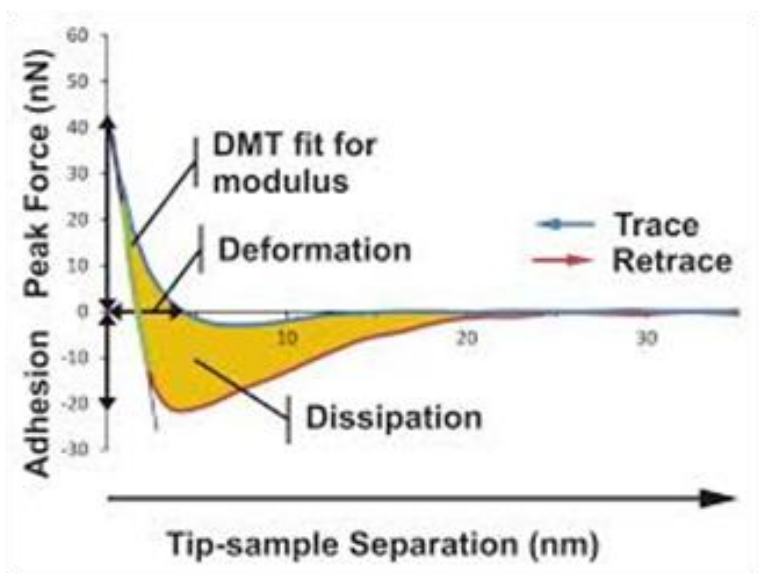

FIGURA 14 - Gráfico de força em função da distância entre ponta e amostra (MEYER et al., 1965; BONNELL, 1993; PITTENGER, 2012).

\subsubsection{Termogravimétria (TG)}

A termogravimetria foi realizada em termo balança Mettler Toledo, modelo TGA/SDTA - 851, com variação de temperatura entre 25 a $700{ }^{\circ} \mathrm{C}$ e razão de aquecimento de $10 \stackrel{\circ}{\circ} \mathrm{C} \min ^{-1}$ sob atmosfera de nitrogênio com vazão de $50 \mathrm{~mL} \mathrm{~min}{ }^{-1}$. As análises foram realizadas em amostras de polímeros e membranas previamente secas em estufa a vácuo, a temperatura ambiente, durante 30 minutos.

\subsubsection{Espectroscopia de impedância eletroquímica (EIS)}

A análise de condutividade iônica das amostras foi realizada por meio de medidas de espectroscopia de impedância elétrica (EIS) em função da umidade relativa (100\%) e da temperatura (30 a $60 \stackrel{\circ}{\circ}$ ), utilizando-se um potenciostato/galvanostato Solartron acoplado a um analisador de resposta de frequência $(f)$ Solartron 1260, na faixa de frequência de $30 \mathrm{MHz}$ a $0,1 \mathrm{~Hz}$, aplicando uma perturbação de $100 \mathrm{mV}$. A resistência da amostra foi obtida no diagrama de Nyquist $\left(Z^{*}=Z^{\prime}\right.$ - iZ") para $Z$ " próximo de zero em altas frequências (WANG et al., 2012). 
As membranas foram cortadas com um diâmetro de $1,4 \mathrm{~cm}$, pressionadas entre tecidos de carbono nas mesmas dimensões da membrana e colocadas em porta-amostra na câmara de medidas contendo contatos de platina e terminais conectados ao analisador de frequência Solartron 1260. As amostras de membrana foram mantidas na câmara por 24 horas a temperatura ambiente. A avaliação do comportamento da condutividade com o tempo foi realizada sob $100 \%$ de umidade relativa.

A condutividade iônica $(\sigma)$ foi calculada utilizando-se as Eq. 28 e 29, a partir dos valores de resistência $\left(\mathrm{R}_{\mathrm{i}}\right)$ obtidos dos espectros de impedância eletroquímica:

$$
\begin{gathered}
\sigma=\frac{L}{R_{i} \times A} \\
A=W x T
\end{gathered}
$$

sendo, $R_{\mathrm{i}}$ a resistência da membrana obtida a partir da intersecção do arco do círculo (ou da sua extrapolação) no eixo real do espectro na representação de Nyquist, $L$ distância entre as duas sondas, $A$ área da seção transversal, $\mathrm{W}$ a massa da amostra, e T espessura da amostra.

As energias de ativação foram calculadas pela Eq. 30:

$$
E a=-b \times R
$$

sendo, $\mathrm{R}$ a constante dos gases $8,3144621 \mathrm{~J} \mathrm{~K}^{-1} \mathrm{~mol}^{-1} \mathrm{e} \mathrm{b}$ a inclinação da reta obtida no gráfico Arrhenius. 


\section{RESULTADOS E DISCUSSÃO}

\subsection{Polietileno de Baixa Densidade (LDPE) e Polietileno de Ultra Alto Peso Molecular (UHMWPE)}

\subsubsection{Identificação e decaimento dos radicais}

A estabilidade e o decaimento da concentração dos radicais dos filmes dos polímeros hidrocarbonetos LDPE e de UHMWPE pré-irradiados a 70 kGy no acelerador de elétrons a temperatura ambiente e armazenados a baixa temperatura (-70 $\left.\pm 4 \quad{ }^{\circ} \mathrm{C}\right)$ foram analisados durante seis meses por espectroscopia de ressonância paramagnética (EPR). Os espectros EPR foram obtidos a temperatura ambiente.

A estabilidade dos radicais formados após a irradiação dos filmes de LDPE e UHMWPE foram caracterizados pela variação da intensidade dos sinais de EPR dos diferentes tipos de macroradicais poliméricos formados após o processo de irradiação em função do tempo de armazenamento a baixa temperatura e pelo fator $g$ calculado por meio da Eq. 27.

O decaimento dos radicais em função do tempo de armazenamento a baixas temperaturas foi estimado pela variação da amplitude do sinal de EPR pico-a-pico normalizado dos radicais peroxila (pico central predominante)

Nas FIG. 15 e 16 são mostradas as variações da intensidade dos sinais de EPR dos diferentes tipos de macroradicais formados durante o processo de irradiação dos polímeros LDPE e UHMWPE após 7 dias de armazenamento a baixa temperatura.

Os espectros EPR dos filmes de LDPE e UHMWPE apresentaram múltiplos sinais e uma linha central de ressonância com fator $g$ aproximadamente 2,03 (próximo a região do campo magnético $350 \mathrm{mT}$ ) com variadas amplitudes em função do tipo de polímero, nível de oxidação e da concentração de radicais não-oxidados (alquila e alila). (FEL, et al., 2015). Comportamento semelhante foi observado por FEL et al. ( 2015), BUTTAFAVA, 2007, e por ALBANO et al. (2003) ao estudarem o decaimento de LDPE, LLDPE, HDPE, e PP em diferentes condições de irradiação e armazenamento. 
No espectro de EPR do LDPE, que é um polímero parcialmente cristalino (50 a 60\%) e cadeia ramificada (COUTINHO et al,.2003), foi possível observar a predominância de sinais equivalentes aos radicais peroxila (ROO), com fator $g=2,029$, e 2,019, e macroradicais alquila e alila com fator $g$ estimado 2,003 e 1,9792, estimados utilizando a EQ. 27. Estes valores são próximos aos reportados por FEL et al. (2015), BUTTAFAVA, 2007, e por ALBANO et al. (2003), respeitando os diferentes parâmetros definidos na análise de EPR.

Enquanto, no espectro do UHMWPE, polímero de alta densidade e com cristalinidade em torno de $45 \%$ e cadeia longa sem ramificações (COUTINHO et al., 2003), exibiu sinal de múltiplas linhas de macroradicais do tipo alila (R·) e radicais oxidados, peroxila (ROO.). O valores do fator $g$ calculados, utilizando a Eq. 27 dos marcroradicais alila foram 2,003 $\left(P_{1}\right) ; 1,9794\left(P_{2}\right)$ e 1,9960 $\left(P_{3}\right)$ respectivamente, e os radicais peroxila 2,026 $(\mathrm{g})$. Os valores obtidos do fator $\mathrm{g}$ são semelhantes aos observados por FEL et al. (2015) e por ALBANO et al. (2003).

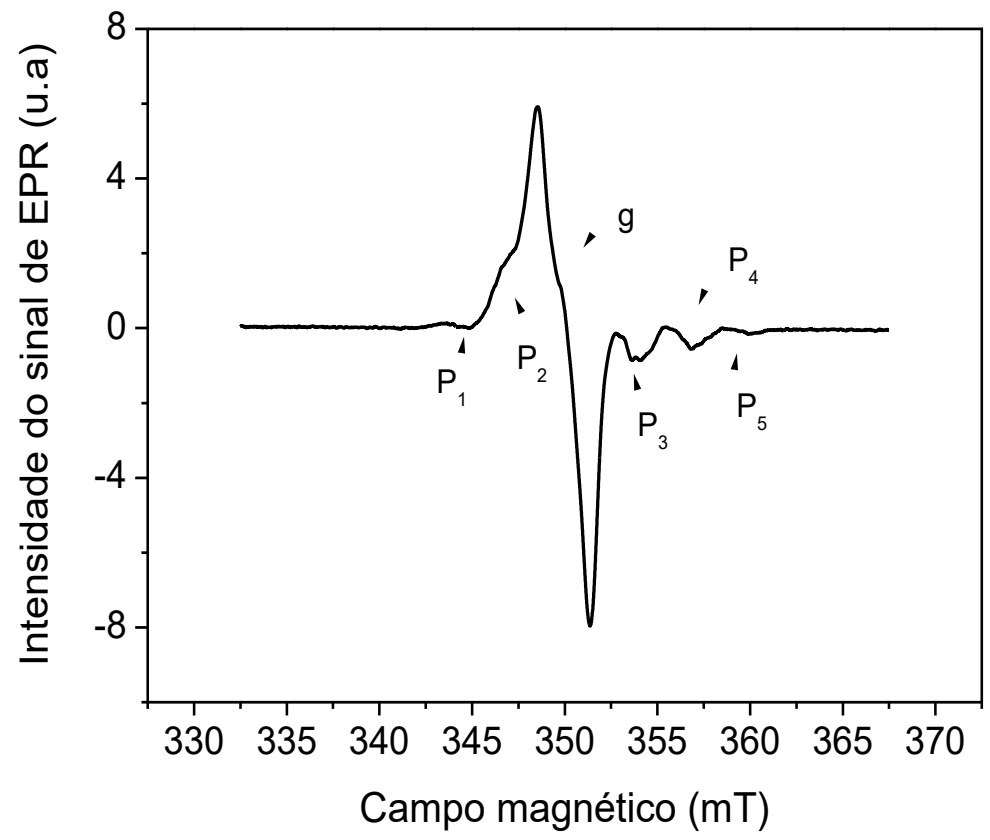

FIGURA 15 - Espectro EPR do LDPE pré-irradiado a 70 kGy após 7 dias e armazenados à baixa temperatura $(-70 \pm 4 \stackrel{\circ}{\circ})$, irradiados e medidos a temperatura ambiente. (u.a. - unidade arbitrária). 


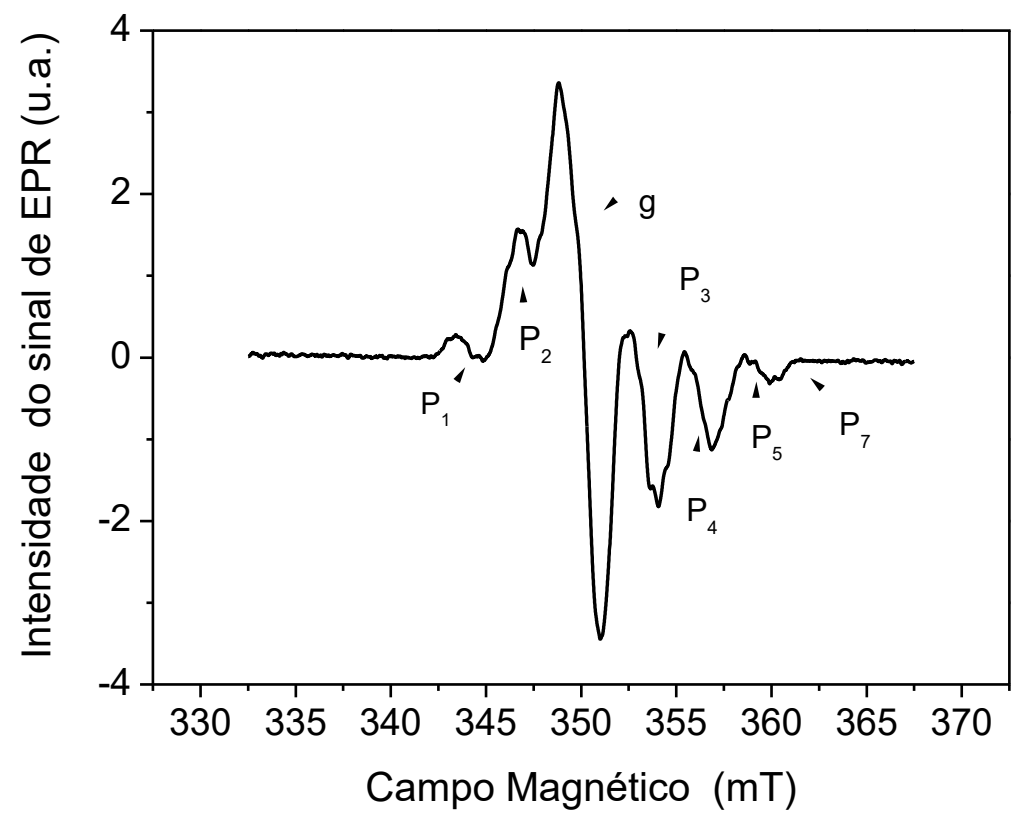

FIGURA 16 - Espectro EPR do UHMWPE pré-irradiado a 70 kGy após 7 dias e armazenados à baixa temperatura ( $-70 \pm 4 \stackrel{\circ}{ } \mathrm{C}$ ), irradiados e medidos a temperatura ambiente.

Nas FIG. 17 e 18 são mostradas as variações das intensidades do sinal de EPR em função do tempo de armazenamento a baixa temperatura (-70 \pm 4 C) dos filmes pré-irradiados de LDPE e de UHMWPE.

As alterações observadas na intensidade do sinal de EPR do LDPE durante seis meses de armazenamento a $-70 \pm 4{ }^{\circ} \mathrm{C}$ (FIG. 17) mostraram que radicais alquila e alila (picos $P_{3}, P_{4}$ e $P_{5}$ da FIG.16) foram convertidos em radicais peróxila (pico central $\mathrm{g}$ ). $\mathrm{O}$ fatores $g$ apresentou pequenas variações $\mathrm{e}$ com o valor $g=2,019$ após 6 meses, indicando a presença predominante de radicais peroxila. Estes resultados foram similares aos reportados por FEL et al. (2015) e ALBANO et al. (2003) ao estudarem o decaimento de LDPE em diferentes condições de irradiação e armazenamento. 


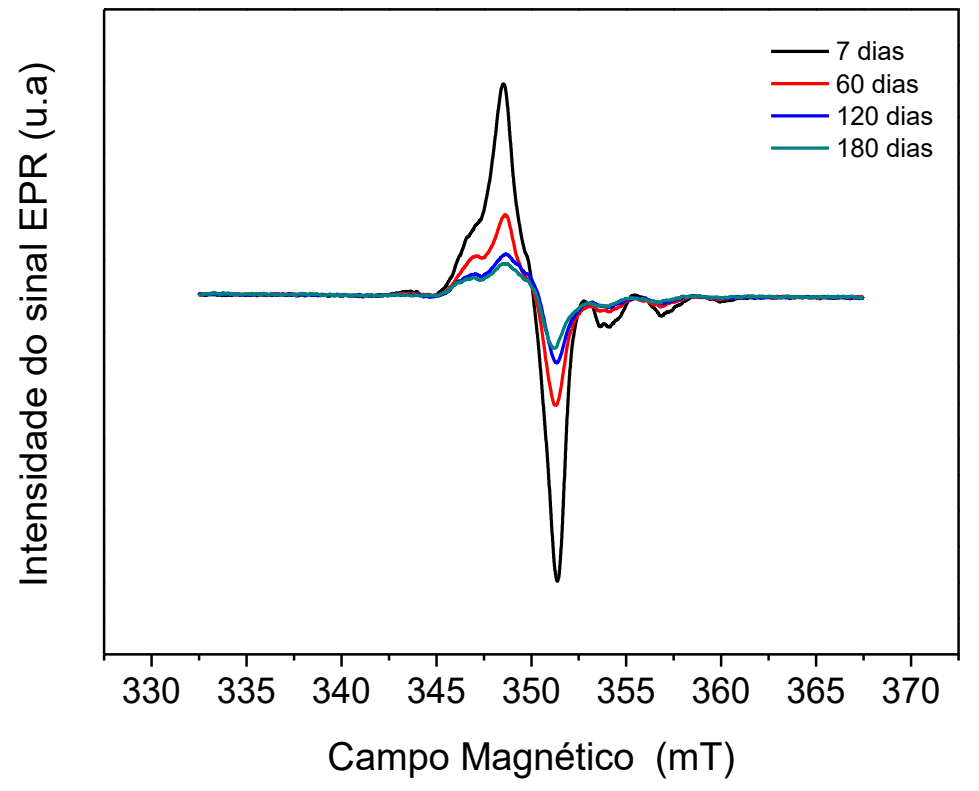

FIGURA 17 - Espectros EPR de filmes de LDPE pré-irradiados a 70 kGy e armazenados a baixa temperatura $\left(-70 \pm 4^{\circ} \mathrm{C}\right)$ durante 180 dias, irradiados e medidos a temperatura ambiente.

A variação da intensidade de sinal de EPR do UHMWPE armazenado durante seis meses a $-70 \pm 4 \stackrel{\circ}{\circ}$ (FIG. 18) mostrou uma alteração pouco significativa nas formas dos espectros em relação à análise após sete dias, além do decaimento dos radicais. Os valores do fator $g$ permaneceram praticamente sem alterações indicando a presença de radicais alquila, alila e peroxila, $g=2,003$ e 2,026, respectivamente. 


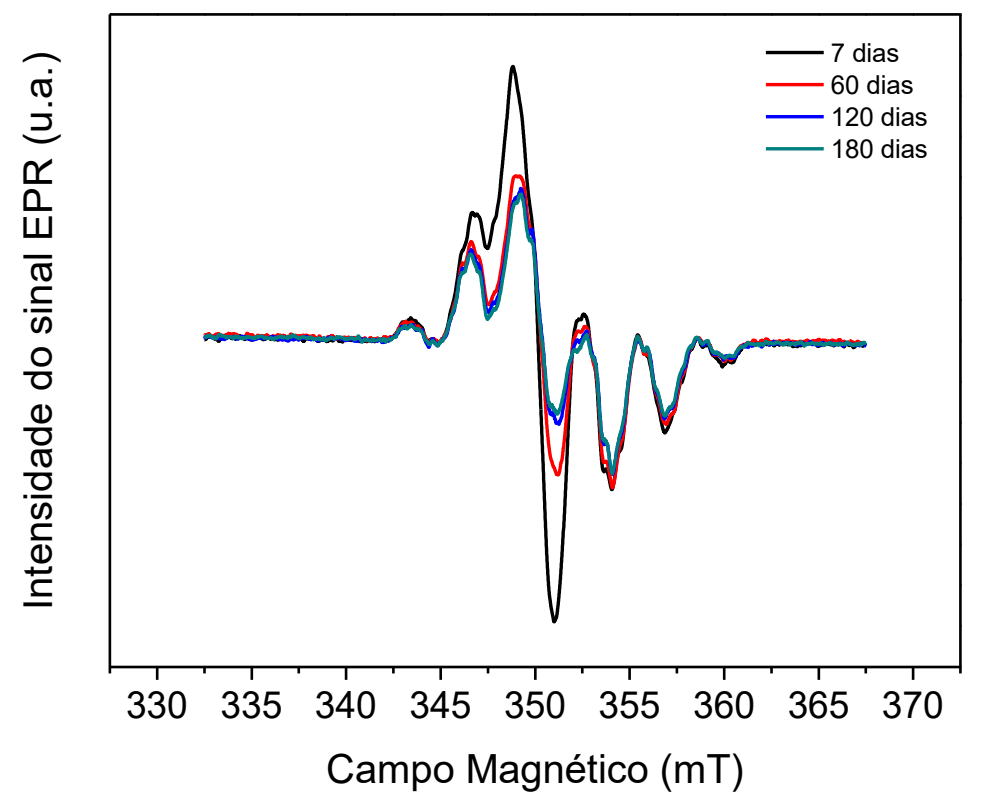

FIGURA 18 - Espectros EPR de filmes de UHMWPE pré-irradiados a $70 \mathrm{kGy}$ e armazenados a baixa temperatura $\left(-70 \pm 4{ }^{\circ} \mathrm{C}\right)$ durante 180 dias, irradiados e medidos a temperatura ambiente.

A análise do decaimento dos radicais peroxila dos polímeros de LDPE e UHMWPE, em função do tempo de armazenamento a $-70 \pm 4^{\circ} \mathrm{C}$, seguiram um ajuste exponencial (FIG. 19). O LDPE apresentou um decaimento de $83 \%$ dos radicais na forma peroxila após 6 meses (Eq.31). A mesma tendência exponencial foi observada no UHMWPE (Eq.32), com decaimento de $60 \%$ dos radicais peroxila. Neste estudo, foram comparados apenas radicais peroxila, visto como observado anteriormente (FIG 18), somente o UHMWPE exibiu intensidade de sinal de EPR de radicais alila e alquila após 60 dias.

$$
\begin{gathered}
Y_{\text {PELD }}=1,62 x E 08^{*} \exp (-x / 38,2)+2,93 x E 07(R=0,99431) \\
Y_{\text {PEUHMW }}=3,80 x E 07^{*} \exp (-x / 42,1)+2.12 x E 07 \quad(R=0,99819)
\end{gathered}
$$




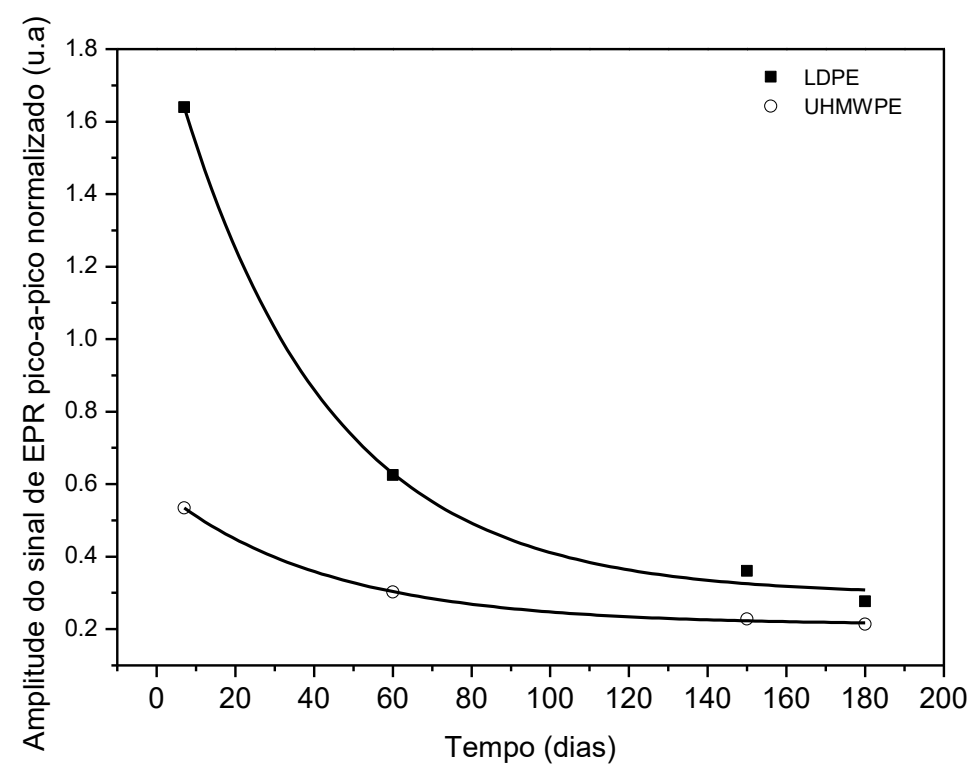

FIGURA 19 - Amplitude do sinal EPR pico-a-pico normalizado versus tempo de armazenamento a baixa temperatura $\left(-70 \pm 4^{\circ} \mathrm{C}\right)$ dos filmes de LDPE e UHMWPE, pré-irradiados a $70 \mathrm{kGy}$ e armazenados a baixa temperatura $(-70 \pm 4 \stackrel{\circ}{\circ})$ durante 180 dias, irradiados e medidos a temperatura ambiente.

O LDPE apresentou uma maior concentração de radicais peroxila e um decaimento mais rápido comparado ao UHMWPE. ALBANO et al. (2003) e FEL et al. (2015) observaram que o decaimento e a estabilidade dos radicais estão relacionados com a linearidade e a facilidade de recombinação dos radicais. No UHMWPE, linear e com maior cristalinidade, os radicais formados permanecem presos nas regiões cristalinas, enquanto que no poletileno LDPE, com cadeias ramificadas, o decaimento dos radicais é favorecido pela reação de recombinação dos radicais presentes na região amorfa.

No caso dos filmes de polietileno (PE) produzidos pelo processo de préirradiação os radicais primários são formados por abstração do hidrogênio e pela cisão da cadeia principal. O decaimento dos radicais em polímeros cristalinos, principalmente PE, segundo ALABANO et al (2003), envolve dois processos: um rápido nas regiões amorfas (devido principalmente aos radicais menos estáveis) e ocorre geralmente no início do experimento, e outro lento, devido a difusão dos radicais do interior do cristal para a sua superfície para 
reagir nas regiões cristalinas. Esta hipótese pode explicar a maior concentração de radicais alila, alquila e peroxila nas amostras de UWMWPE após seis meses.

Estes resultados indicaram que, os radicais formados após a irradiação dos polímeros de LDPE e de UHMWPE, armazenados a baixa temperatura ( $-70 \pm 4 \stackrel{\circ}{\circ}$ ), foram preservados por até 6 meses.

FEL et al. (2015) concluiram que a concentração final dos radicais depende da temperatura de armazenamento. Temperaturas positivas de armazenamento favorecem a mobilidade dos macroradicais e as reações de recombinação, enquanto a baixas temperaturas os radicais permanecem aprisionados nas macroestruturas estáveis das regiões cristalinas ou próxima as interfaces das regiões amorfas e cristalina, regiões de difícil acesso ao $\mathrm{O}_{2}$.

\subsubsection{Caracterização DOG, IEC e WU}

Na TAB. 7 são apresentados os valores de DOG, IEC e WU para as membranas sintetizadas com os filmes LDPE $(125 \mu \mathrm{m})$ e de UHMWPE $(200 \mu \mathrm{m})$ pré-irradiados e armazenadas a baixa temperatura $\left(-70 \pm 4{ }^{\circ} \mathrm{C}\right)$ durante 10 meses. A enxertia foi realizada em solução de monômero de estireno: propano-2-ol (60:40 v:v) a temperatura ambiente por 24 horas. Foram apresentados os resultados após a reação de sulfonação em solução de ácido clorossulfônico em dicloroetano $0,2 \mathrm{M}$, e após a reação de alquilação em solução de solução aquosa de hidróxido de potássio $1 \mathrm{~mol} \mathrm{~L}^{-1}$.

TABELA 7- Resultados de DOG, IEC, WU das membranas de LDPE e de UHMWPE

\begin{tabular}{ccccccc}
\hline Membrana & $\begin{array}{c}\text { DOG } \\
(\%)\end{array}$ & $\begin{array}{c}\text { IEC sulfonação } \\
\left(\mathrm{m} \mathrm{molg}^{-1}\right)\end{array}$ & $\begin{array}{c}\text { Espessura } \\
\text { úmida } \\
(\mu \mathrm{m})\end{array}$ & $\begin{array}{c}\text { WU } \\
(\%)\end{array}$ & $\begin{array}{c}\lambda \\
{\left[\mathrm{mol}\left(\mathrm{H}_{2} \mathrm{O}\right) /\right.} \\
\mathrm{mol}(\mathrm{OH}-)]\end{array}$ & $\begin{array}{c}\text { IEC } \\
\left(\mathrm{m} \mathrm{molg}^{-1}\right)\end{array}$ \\
\hline PELD & 32 & 0,33 & 172 & 73 & 0,02 & 1,60 \\
PEUHMW & 192 & 1,09 & 465 & 175 & 0,11 & 0,92 \\
\hline
\end{tabular}

O UHMWPE com maior concentração de radicais, como observado na análise de decaimento realizada por EPR, exibiu maior grau de enxertia (DOG) comparado ao LDPE, e consequentemente maior IEC de sulfonação. 
O maior número de grupos sulfônicos disponíveis para reação (IEC) presentes no UHMWPE, entretanto ocasionou um aumento da absorção de água (WU), $\lambda$, e intumescimento da membrana (maior espessura) reduzindo 0 IEC da membrana final.

A membrana de LDPE com valores menores de IEC de sulfonação, WU e $\lambda$, mostrou maior IEC. Os resultados foram próximos aos obtidos por MANLOUK et al. (2012), em membranas aniônicas obtidas com filmes de LDPE (40 e $50 \mu \mathrm{m}$ ) enxertados com VBC e funcionalizadas com TMA pelo processo simultâneo. ESPIRITU et al (2015) utilizando este mesmo processo, obtiveram valores de IEC de até $2,3 \mathrm{~m} \mathrm{~mol} \mathrm{~g}^{-1}$, em membranas preparadas com filmes de LDPE $(130 \mu \mathrm{m})$

\subsubsection{Espectroscopia Raman}

As análises das fases de enxertia e quaternização das membranas de LDPE e UHMWPE após 10 meses são mostradas nas FiG. 20 e 21. O espectro Raman para as membranas enxertadas apresentou estiramentos correspondentes aos anéis aromáticos em $1611 \mathrm{~cm}^{-1}$; C-C aromático em 1187 $\mathrm{cm}^{-1}$; C-Cl em 1001 e $1271 \mathrm{~cm}^{-1}$ e correspondentes a grupos aminas C-N incorporados após processo de quaternização em 425; 759; 800; 1100 e1477 $\mathrm{cm}^{-1}$ (SARAH et al., 2014).

O espectro do filme de LDPE (não irradiado), parcialmente cristalino, contem estiramentos $\mathrm{CH}_{2}$ na fase cristalina $\left(1360 \mathrm{~cm}^{-1}, 1339 \mathrm{~cm}^{-1}, 1090 \mathrm{~cm}^{-1}\right)$, estiramentos $\mathrm{CH}_{3}$ na fase amorfa $\left(1283 \mathrm{~cm}^{-1}\right)$, e estiramento C-C $\left(1045 \mathrm{~cm}^{-1}\right.$, $981 \mathrm{~cm}^{-1}$ ) (FURUKAWA et al., 2006). O filme de LDPE após a reação de enxertia com monômero de estireno apresentou estiramentos correspondentes ao anel aromático $\left(1530 \mathrm{~cm}^{-1}, 1504 \mathrm{~cm}^{-1} ;\right.$ m) e C-C aromático em $\left(1116 \mathrm{~cm}^{-1}\right.$, •). (SARAH et al., 2014). $\mathrm{Na}$ análise da membrana os grupos amina $\mathrm{C}-\mathrm{N}$ adicionados após a reação de quaternização não ficaram claramente definidos no espectro. 


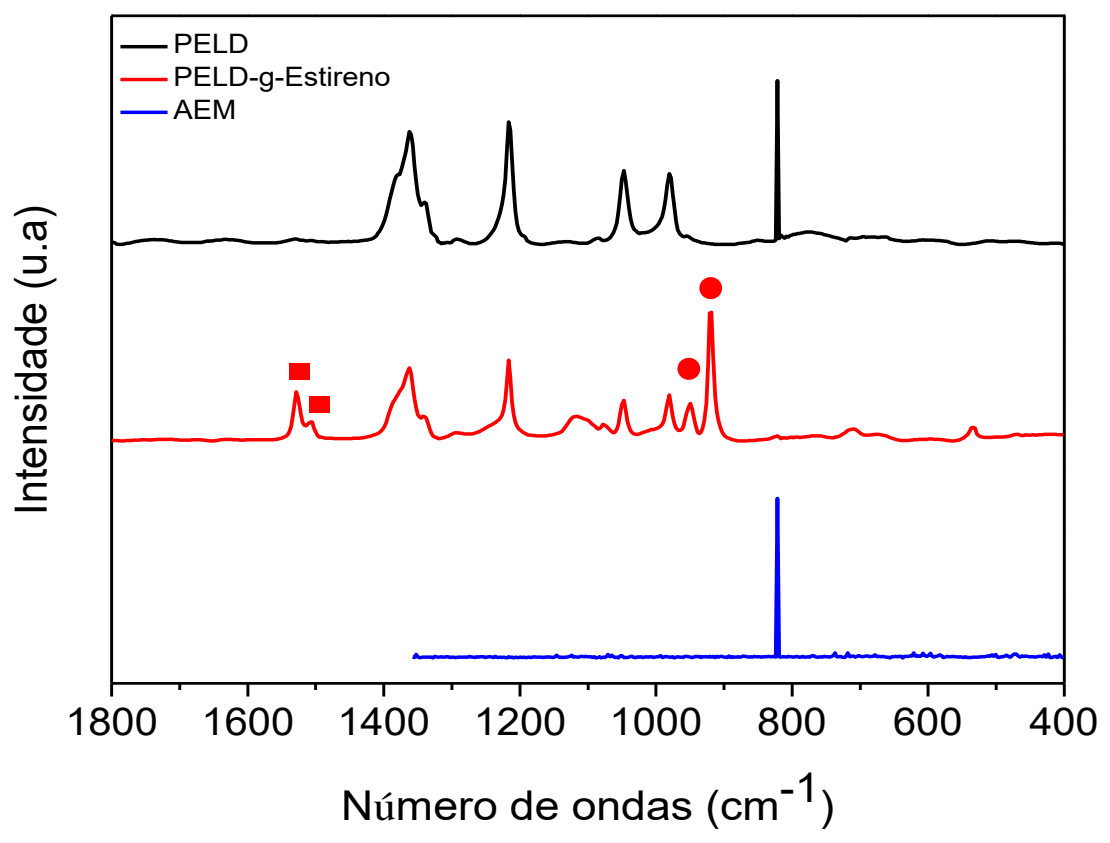

FIGURA 20 - Espectro Raman do LDPE não-irradiado (LDPE), LDPE após enxertia com solução monômero de estireno: propano-2-ol (60:40 v:v) (LDPE-g-Estireno), e membrana de troca aniônica na forma $\mathrm{OH}^{-}$(AEM). $\mathrm{O}$ espectro foi obtido no intervalo de $400-2000 \mathrm{~cm}^{-1}$, laser $532 \mathrm{~nm}$.

O espectro do filme de UHMWPE (não irradiado) contem estiramentos $\mathrm{CH}_{2}$ na fase cristalina $\left(1362 \mathrm{~cm}^{-1}, 1339 \mathrm{~cm}^{-1}, 1079 \mathrm{~cm}^{-1}\right)$, estiramentos $\mathrm{CH}_{3}$ na fase amorfa (1294 cm $\left.\mathrm{cm}^{-1}\right)$, e estiramento C-C (1049 cm $\left.\mathrm{cm}^{-1}, 981 \mathrm{~cm}^{-1}\right)$ (FURUKAWA et al., 2006).O filme de PEUHMW após a reação de enxertia com monômero de estireno apresentou estiramentos correspondentes ao anel aromático (1529 cm $\left.\mathrm{cm}^{-1}, 1500 \mathrm{~cm}^{-1} ; \mathbf{m}\right)$, C- C aromático $\left(1120 \mathrm{~cm}^{-1}, 1076 \mathrm{~cm}^{-1}\right.$, v), $\mathrm{C}=\mathrm{C}$ aromático $\left(950 \mathrm{~cm}^{-1}, 920 \mathrm{~cm}^{-1}, \bullet\right)$. (SARAH et al., 2014). A amostra ao final da reação de quaternização apresentou os estiramentos C-N $\left(1524 \mathrm{~cm}^{-1}\right.$, $\left.1134 \mathrm{~cm}^{-1}, 773 \mathrm{~cm}^{-1}, \diamond\right)$ indicando a presença de grupos de amônio quaternário $\left(-\mathrm{N}^{+}\left(\mathrm{CH}_{3}\right)_{3}\right)$. Resultados semelhantes foram encontrados por SARAH et al., 2014; POYNTON et al, 2015; GONZALEZ et al., 2016. 


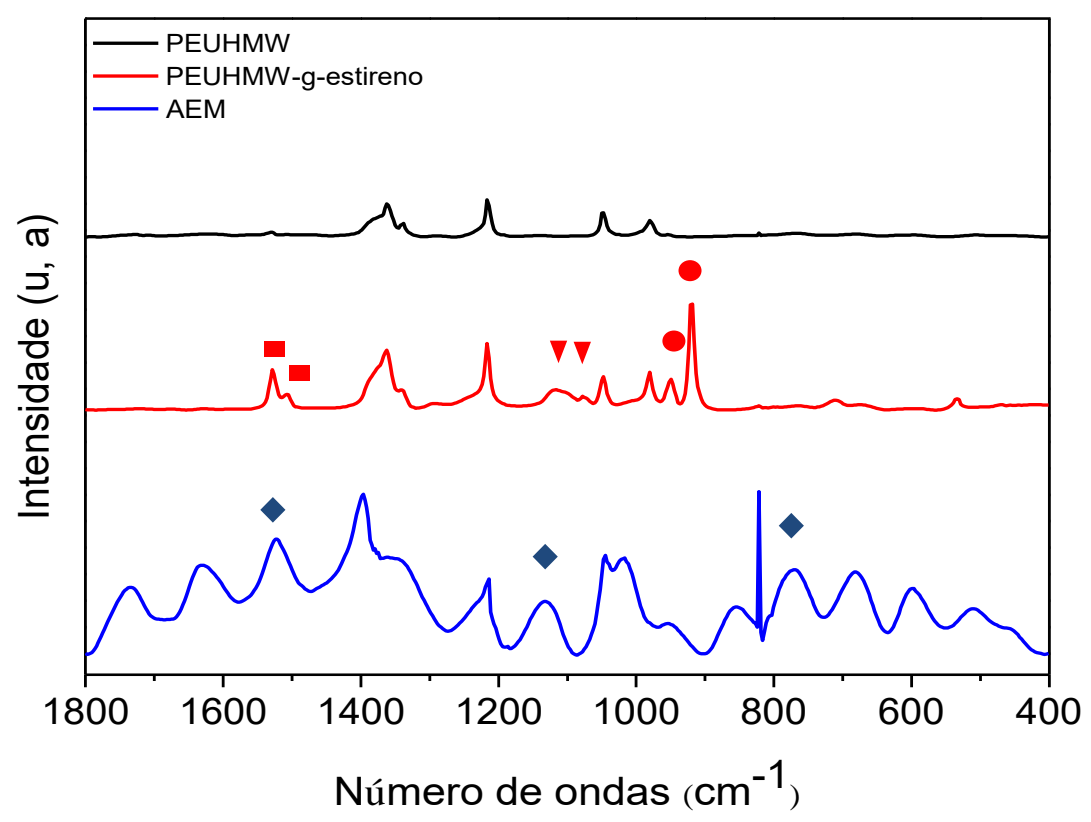

FIGURA 21 - Espectro Raman do UHMWPE não-irradiado (LDPE), UHMWPE após enxertia com solução monômero de estireno:propano-2-ol (60:40 v:v) (UHMWPE-gEstireno), e membrana de troca aniônica na forma $\mathrm{OH}^{-}(\mathrm{AEM})$. O espectro foi obtido no intervalo de $400-2000 \mathrm{~cm}^{-1}$, laser $532 \mathrm{~nm}$.

\subsubsection{Termogravimetria}

Nas FIG. 22 e 23 são mostradas as curvas de TG e sua derivada primeira, DTG (mg $\mathrm{min}^{-1}$ ) obtidas em atmosfera de nitrogênio dos filmes de LDPE não irradiado, filmes de LDPE pré-irradiados em feixe de elétrons na dose de 70 kGy e enxertados com monômero de estireno (solução 60:40 estireno:propano-2-ol, v:v), e membrana aniônica na forma $\left(\mathrm{OH}^{-}\right)$. 


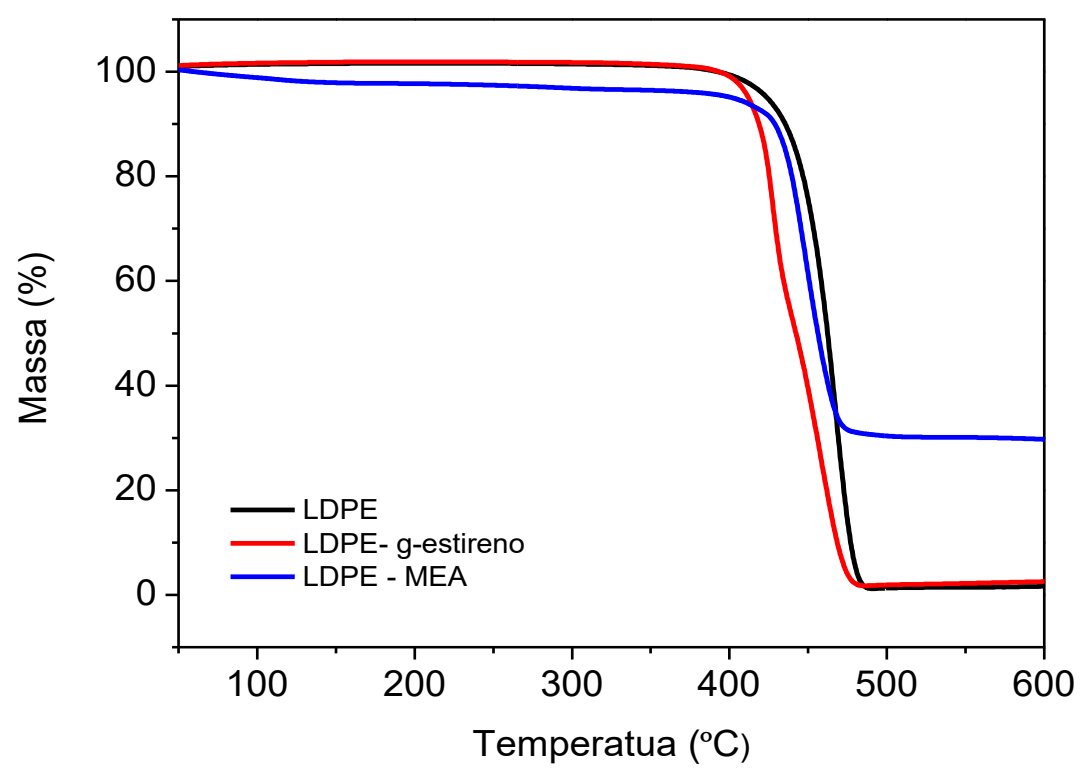

FIGURA 22 - Curvas de TG das amostras: (a) LDPE não irradiadas, (b) pré-irradiada a 70 kGy e enxertadas em solução de estireno: propano-2-ol (60:40 v:v),e (c) membrana aniônica na forma $\left(\mathrm{OH}^{-}\right)$obtidas a $10 \stackrel{\circ}{\circ} \mathrm{min}^{-1}$ e sob atmosfera de $\mathrm{N}_{2}$.

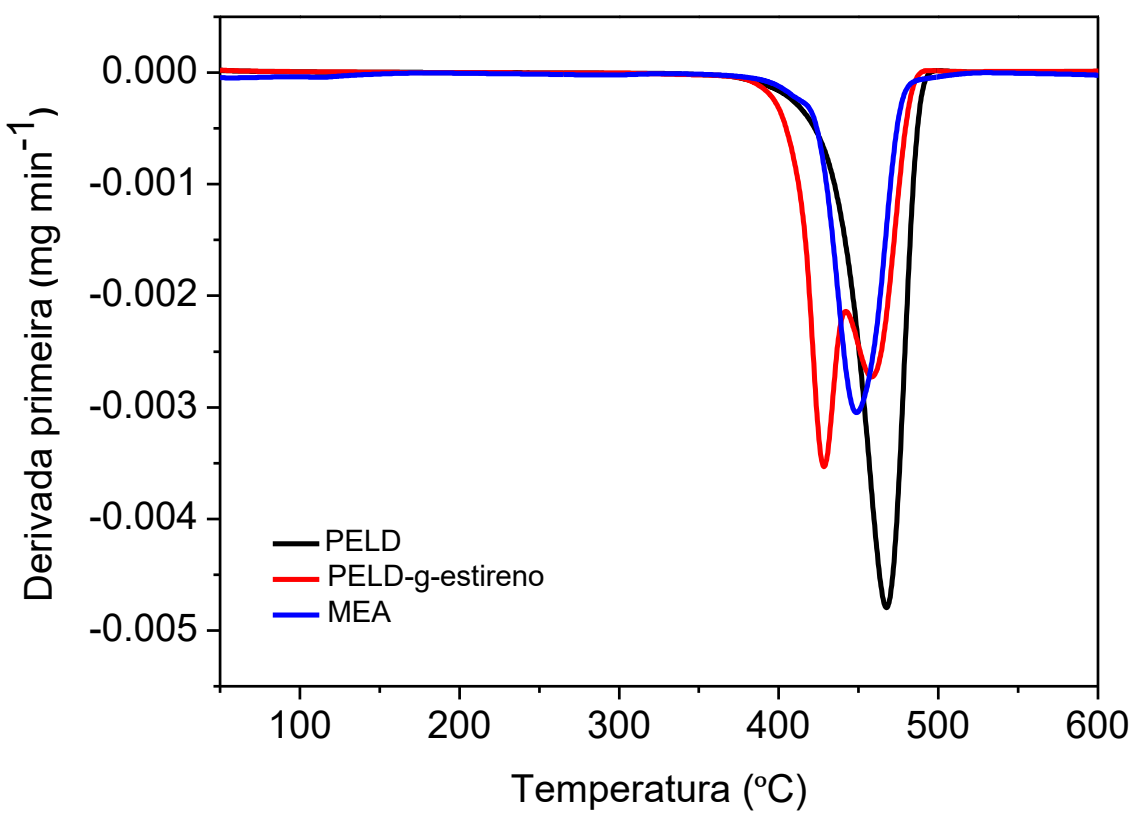

Figura 23- Curvas DTG das amostras de LDPE: (a) não irradiada, (b) pré-irradiada a 70 kGy e enxertadas com estireno (solução estireno: propano-2-ol),e membrana aniônica na forma $\left(\mathrm{OH}^{-}\right)$, obtidas a $10 \stackrel{\circ}{\circ} \mathrm{C} \mathrm{min}^{-1}$ sob atmosfera de $\mathrm{N}_{2}$ 
No filme de LDPE não irradiado foi observado um único evento de perda de massa, atribuído a decomposição da matriz polimérica do LDPE na temperatura de $470^{\circ} \mathrm{C}$ (FIG. 22).

Após a enxertia com o monômero de estireno, foram observadas duas etapas de degradação iniciando em $410{ }^{\circ} \mathrm{C}$ (Tonset) (FIG 22), a primeira atribuída à degradação do monômero de estireno enxertado em $430 \mathrm{C}$, e a segunda à decomposição da cadeia do polímero de LDPE em 460 ํ (FIG. 23).

Na membrana de LDPE na forma $\left(\mathrm{OH}^{-}\right)$a perda de massa ocorreu gradativamente até a temperatura de $420 \stackrel{\circ}{\circ}$, onde iniciou a decomposição do monômero de estireno enxertado e da cadeia do polímero de LDPE. A perda de massa inicial até cerca de $260{ }^{\circ} \mathrm{C}$ pode ser atribuída a eliminação de água da membrana, solvente, monômero, grupos quaternário de amônio, e grupos sulfônicos (FIG 22) (MAURYA et al, 2013). Embora tenha iniciado à temperaturas inferiores a $100^{\circ} \mathrm{C}$ e os produtos eliminados não foram analisados, a membrana de LDPE, apresentou retenção de água até cerca de $260 \stackrel{\circ}{ } \mathrm{C}$, definindo uma faixa de temperatura suficiente para aplicação em AFC no estado hidratado. A decomposição do monômero de estireno enxertado e da cadeia do polímero ocorreu em $460 \stackrel{\circ}{\circ}$. A temperatura de término do estudo da degradação das amostras ocorreu em $700 \stackrel{\circ}{ } \mathrm{C}$.

Os teores de resíduo obtidos nas amostras dos filmes de LDPE não irradiados e enxertados com monômero de estireno foram, respectivamente, de 2,01 e $2,83 \%$. Na membrana de LDPE na forma $\left(\mathrm{OH}^{-}\right)$o resíduo de $27 \%$ pode ser associado presença de resíduos de enxofre e alguma substancia inorgânica formada durante a reação de enxertia. Os resíduos não foram analisados.

Nas FIG. 24 e 25 são mostradas as curvas de TG e sua derivada primeira, DTG (mg min ${ }^{-1}$ ) obtidas em atmosfera de nitrogênio dos filmes de UHMWPE não irradiado, filmes de UHMWPE pré-irradiados em feixe de elétrons na dose de 70 kGy e enxertados com monômero de estireno (solução 60:40 estireno:propano-2-ol, v:v), e membrana aniônica na forma $\left(\mathrm{OH}^{-}\right)$. 


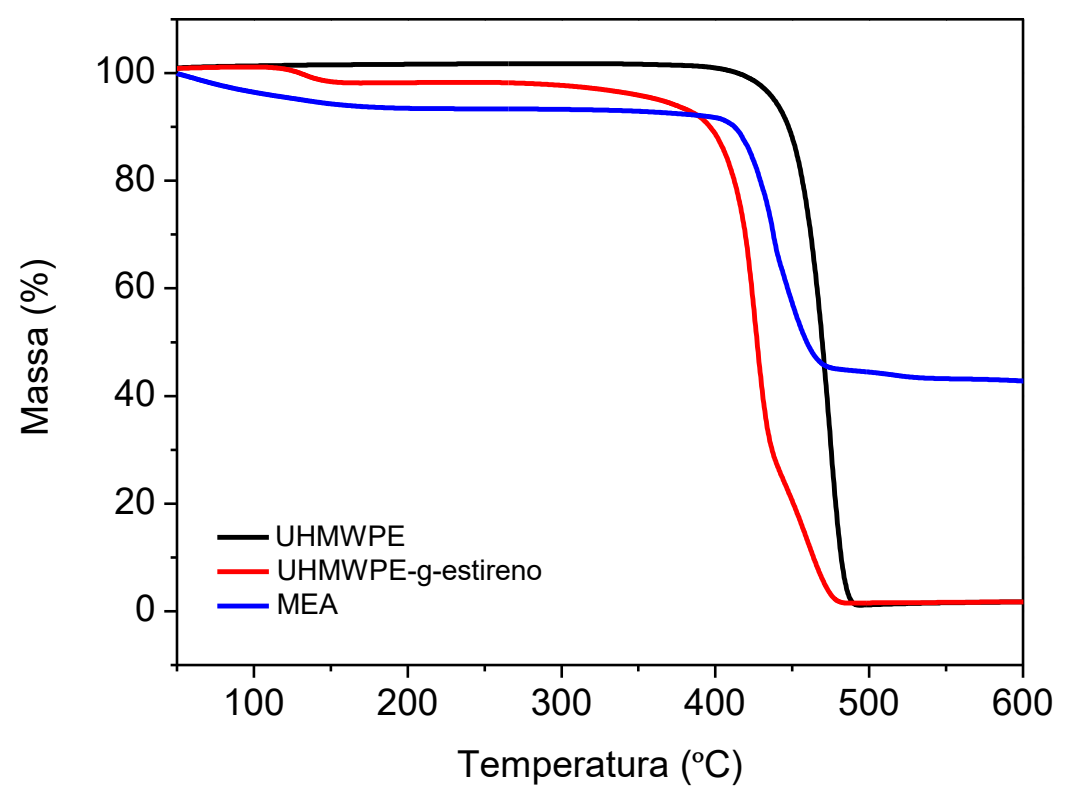

FIGURA 24 - Curvas TG das amostras: (a) UHMWPE não irradiadas, (b) UHMWPE pré-irradiada em feixe de elétrons a 70 kGy e enxertadas com estireno (solução 60:40 estireno: propano-2-ol, v:v),e (c) membrana aniônica na forma ( $\mathrm{OH}-$ ); obtidas com razão de aquecimento de $10 \stackrel{\circ}{\circ} \mathrm{C} \mathrm{min}^{-1}$ e sob atmosfera de $\mathrm{N}_{2}$.

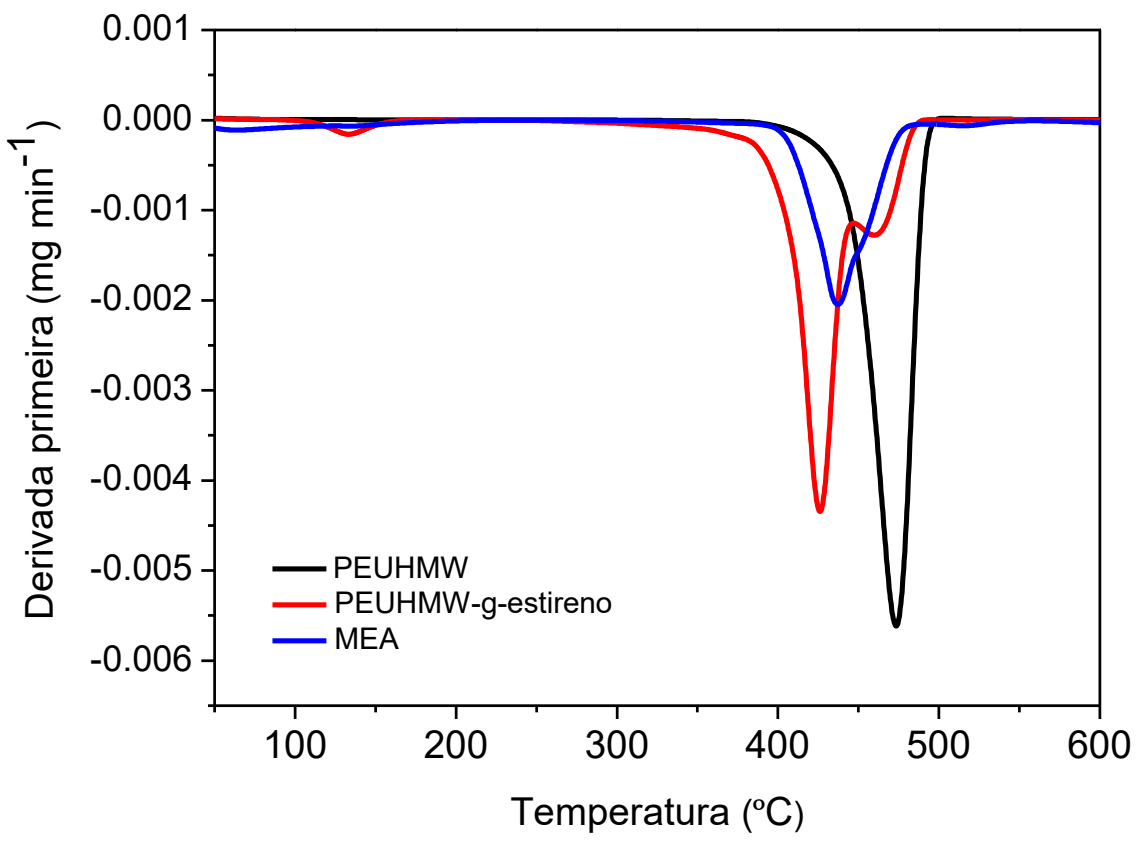

FIGURA 25 - Curvas DTG das amostras de UHMWPE: (a) não irradiada, (b) UHMWPE pré-irradiada a $70 \mathrm{kGy}$ em feixe de elétrons e enxertadas com estireno (solução estireno: propano-2-ol),e membrana aniônica na forma $\left(\mathrm{OH}^{-}\right)$, obtidas com razão de aquecimento de $10 \stackrel{\circ}{\circ} \mathrm{min}^{-1} \mathrm{sob}$ atmosfera de $\mathrm{N}_{2}$, 
O filme de UHMWPE não irradiado apresentou um evento único de perda de massa, atribuído à decomposição da matriz polimérica do UHMWPE em $480^{\circ} \mathrm{C}$ (FIG. 25).

Após a enxertia com o monômero de estireno, foram observadas duas etapas de degradação iniciando em $400{ }^{\circ} \mathrm{C}$ (Tonset), a primeira etapa em $430^{\circ} \mathrm{C}$ atribuída à degradação do monômero de estireno enxertado, e a segunda em 460 ํ $\mathrm{C}$ atribuída à degradação da cadeia do polímero, observados na FIG. 25.

Na membrana de UHMWPE na forma $\left(\mathrm{OH}^{-}\right)$, assim como observado na membrana de LDPE, a perda de massa ocorreu gradativamente até a temperatura de $410 \stackrel{\circ}{ } \mathrm{C}$, onde iniciou a decomposição do monômero de estireno enxertado e da cadeia do polímero UHMWPE. A perda de massa inicial até cerca de $250 \stackrel{\circ}{\circ}$ pode ser associada à eliminação de água, solventes, monômeros, grupos quaternário de amônio e grupos sulfônicos (FIG 24), indicando um comportamento da membrana de retenção de água em altas temperaturas. (FIG. 24) (MAURYA et al, 2013). A decomposição do monômero de estireno enxertado e da cadeia do polímero ocorreu em $450 \stackrel{\circ}{\circ}$. A temperatura de término do ensaio da degradação das amostras ocorreu em $700 \stackrel{\circ}{ }$ (FIG. 25).

Os teores de resíduo obtidos nas amostras dos filmes de UHMWPE não irradiados e enxertados com monômero de estireno foram, respectivamente, foram de 2,00 e 1,87 \%. Na membrana de UHMWPE na forma $\left(\mathrm{OH}^{-}\right)$o resíduo de $40 \%$ pode ser associado presença de resíduos de enxofre e alguma substancia inorgânica formada durante a reação de enxertia (SHERAZI et al, 2009). Os resíduos não foram analisados.

Os resultados de temperaturas de início de decomposição térmica observadas para as membranas de LDPE e UHMWPE de $420 \stackrel{\circ}{\circ}$ e $410{ }^{\circ} \mathrm{C}$, respectivamente, indicando que estas membranas possuem estabilidade térmica adequada para a aplicação em célula a combustível alcalina. A estabilidade térmica da membrana de LDPE mostrou-se ligeiramente superior a membrana de UHMWPE. Perdas de massa semelhantes foram previamente relatados por SHEARAZI et al. (2009) e por MAURYA et al. (2013). 
A perda total de massa e o consequente teor de resíduo observados nas membranas LDPE $(27 \%)$ e UHMWPE $(40 \%)$ condizem com os valores de DOG, IEC da reação de sulfonação e WU encontrados para os respectivos polímeros, indicando uma tendência de aumento do teor de resíduo com o aumento do DOG, IEC da reação de sulfonação, e WU. Os resíduos podem ser resultantes da volatilização incompleta dos grupos sulfônicos e homopolímeros formados na reação de enxertia (SHEARAZI et al., 2009).

\subsubsection{Espectroscopia de impedância}

Na FIG. 26 são mostrados os gráficos de condutividade iônica em função da temperatura para membranas de LDPE e de UHMWPE. Pode-se observar uma tendência de aumento de condutividade iônica com o aumento da temperatura, indicando que temperaturas mais elevadas contribuem para a condução aniônica, possivelmente, devido ao aumento da mobilidade dos íons $\mathrm{OH}^{-}$. As membranas de LDPE apresentaram valores de condutividade maiores ( 28,0 mS.cm ${ }^{-1}$ a $\left.60 \stackrel{\circ}{\circ}\right)$, comparativamente à membrana de UHMWPE ( 13,5 $\mathrm{mS} . \mathrm{cm}^{-1}$ a $60{ }^{\circ} \mathrm{C}$ ). Esse resultado é condizente com o maior valor de IEC observado para o LDPE (IEC PELD $=1,6 \mathrm{~m} \mathrm{~mol} \mathrm{~g}^{-1}$ e IEC PEUHMW $=0,92 \mathrm{~m} \mathrm{~mol} \mathrm{~g}^{-1}$ ) indicando que há mais grupos funcionais disponíveis para a condução do $\mathrm{OH}^{-}$.

A condutividade iônica e o desempenho em célula dos polímeros LDPE, HDPE e PETFE enxertados com VBC e funcionalizados com TMA, foram estudados por MANLOUK et al. (2012). As diferenças observadas nos DOG foram causadas pelas propriedades do polímero base, como massa molar, cristalinidade, orientação ou processo de enxertia utilizado. Resultados de condutividade $70 \mathrm{mS} \mathrm{cm}^{-1}$ foram obtidos com membranas LDPE (DOG 47\%, IEC 1,77) 


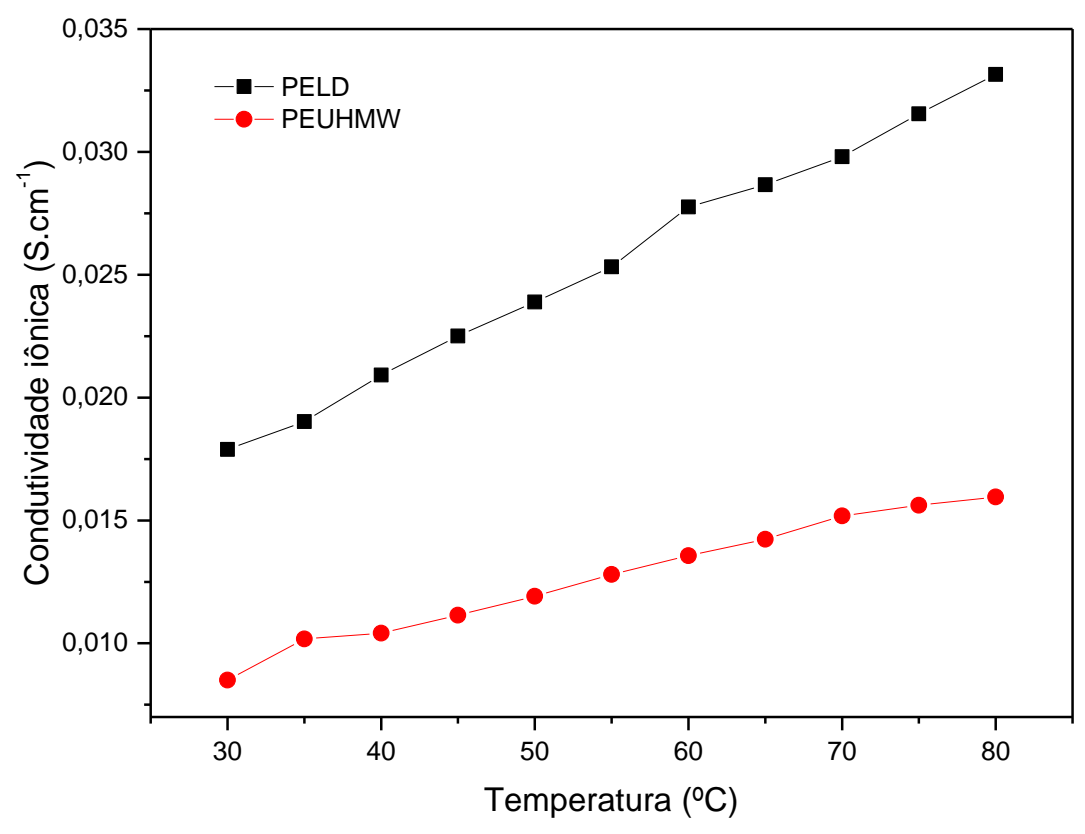

FIGURA 26 - Condutividade iônica das membranas aniônicas dos polímeros de LDPE e de UHMWPE hidratadas na forma $\left(\mathrm{OH}^{-}\right)$. Medidas em $\mathrm{RH}=100 \%$, 2 pontas, faixa de frequência de $30 \mathrm{MHz}$ a $0,1 \mathrm{~Hz}$.

Segundo ESPIRITU et al. (2015), a condutividade aniônica $\left(\mathrm{OH}^{-}\right)$é função da concentração e da mobilidade íons, e é inferior à condutividade em fase aquosa de eletrólitos ácidos como $\circ$ Nafion $^{\mathrm{TM}}\left(\sigma_{\text {proton }} / \sigma_{\text {hidroxila }}=1,76\right)$. Para melhor a condutividade, AEMs com alto IEC foram estudadas, no entanto esta modificação pode causar absorção excessiva de água (WU) ocasionando intumescimento significativo e declínio das propriedades mecânicas da membrana. Os autores estudaram o efeito do grau de enxertia (DOG) e capacidade de troca iônica (IEC) na condutividade e desempenho de AEMs sintetizadas com polietilenos LDPE e UHMWHPE enxertadas com VBC e funcionalizadas com TMA, observaram que membranas com alto DOG exibiram melhores resultados de condutividade, transporte iônico e desempenho em célula. Condutividade iônica de cerca de $120 \mathrm{mS} \mathrm{cm}^{-1}$ a $70^{\circ} \mathrm{C}$, foram obtidos com membrana LDPE com DOG 74,6\% e IEC 3,8 $\mathrm{m} \mathrm{mol} \mathrm{g}^{-1}$. 
No gráfico de Arrhenius mostrados na FIG. 27, observou-se que a resistência das membranas de LDPE e UHMWPE diminui gradativamente com o aumento da temperatura. As energias de ativação, $E_{a}$, estimadas utilizando a equação de Arrhenius (Eq. 30) das membranas LDPE e UHMWPE, são respectivamente, $11,05 \mathrm{~kJ} \mathrm{~mol}^{-1}$ e $10,76 \mathrm{~kJ} \mathrm{~mol}^{-1}$.

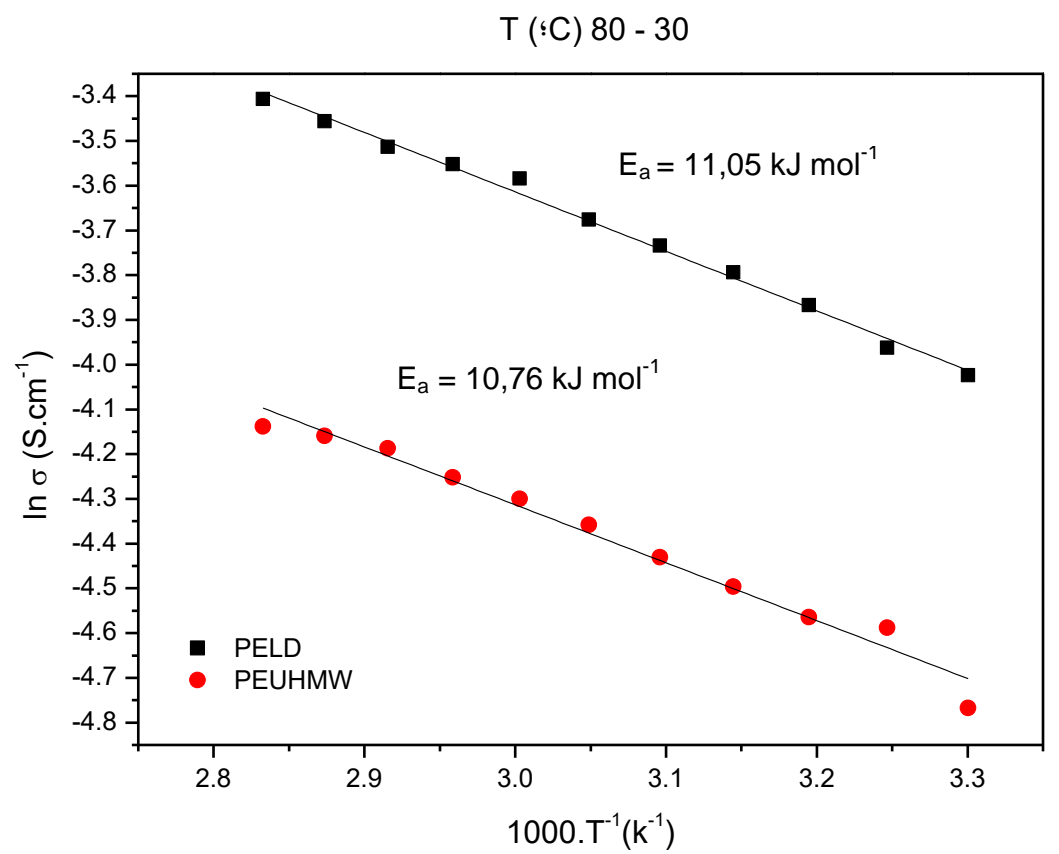

FIGURA 27 - Gráfico de Arrhenius das membranas dos polímeros LDPE e UHMWPE hidratadas na forma $\left(\mathrm{OH}^{-}\right)$. Medidas em $\mathrm{RH}=100 \%$

A energia de ativação, Ea, está relacionada à barreira energética para a migração de anions de um ponto para outro com base no mecanismo Grotthus (JEONG et.al., 2015). O transporte dos íons $\mathrm{OH}^{-}$é facilitado quando a energia de ativação é baixa (JEONG et al., 2015; MAMLOUK e SCOTT, 2012). Neste trabalho, entretanto, a membrana UHMWPE com menor energia de ativação exibiu uma menor condutividade, este comportamento pode ser decorrente das diferenças estruturais dos polímeros, maior espessura e consequentemente maior intumescimento e maior capacidade de absorção de água (WU) da membrana UHMWPE quando comparada a membrana LDPE.

Estes resultados de energia de ativação foram próximos ao reportado na literatura. MAMLOUK e SCOTT (2012) observaram ao estudar o efeito dos grupos funcionais de amônio no desempenho de membranas LDPE enxertadas 
com VBC e funcionalizadas com TMA exibiram a maior condutividade iônica cerca de $43 \mathrm{mS} \mathrm{cm}^{-1}$ a $80 \stackrel{\circ}{\circ} \mathrm{C}$ como consequência da menor energia de ativação, $E_{a}$, cerca de $12 \mathrm{~kJ} \mathrm{~mol}^{-1}$, valor próximo ao Nafion $^{\mathrm{TM}}, 8,5 \mathrm{~kJ} \mathrm{~mol}^{-1}$.

SHERAZI, et al. (2013) relatou condutividades de $30 \mathrm{~ms} \mathrm{~cm}^{-1}$ a $60{ }^{\circ} \mathrm{C}$, para membranas de UHMWPE enxertadas com VBC, e energia de atividade, Ea, cerca de $12,5 \mathrm{~kJ} \mathrm{~mol}^{-1}$ a $28,9 \mathrm{~kJ} \mathrm{~mol}^{-1}$.

Os valores de condutividade obtidos neste trabalho com as membranas LDPE e UHMWPE indicaram a possibilidade de aplicação em células a combustível. Alem disso, é possível melhorar as propriedades e o desempenho destas membranas reduzindo o tempo de armazenamento a baixas temperaturas e otimizando os parâmetros de processo (dose de radiação, tipo de monômero e condições de enxertia, grupos funcionais).

\subsection{Poli(etileno-co-tetrafluoretileno) (PETFE)}

\subsubsection{Processo simultâneo de irradiação}

Os filmes de PETFE foram irradiados nos irradiadores ${ }^{60} \mathrm{Co}$ Gammacell (taxa de dose $1 \mathrm{kGy} \cdot \mathrm{h}^{-1}$ ) e Multipropósito de ${ }^{60} \mathrm{Co}$ (taxa de dose 11,4 kGy. $\mathrm{h}^{-1}$ ) com doses absorvidas de radiação de 20 - 100 kGy pelo processo simultâneo em atmosfera inerte $\left(\mathrm{N}_{2}\right)$ nas seguintes soluções: i) monômero de estireno: estireno:tolueno 60:40 (v:v), ii) estireno:propan-2-ol 60:40 (v:v), iii) estireno:tolueno 20:80 (v:v).

Neste estudo foram analisados a influência dos seguintes parâmetros de processo de irradiação no grau e distribuição da enxertia dos filmes de PETFE: dose e taxa de dose por comparação entre os irradiadores ${ }^{60} \mathrm{Co}$ Gammacell (taxa de dose $1 \mathrm{kGy} \cdot \mathrm{h}^{-1}$ ) e Multipropósito de ${ }^{60} \mathrm{Co}$ (taxa de dose $11,4 \mathrm{kGy} \mathrm{h}{ }^{-1}$ ), concentração de monômero, e tipo de solvente. 
No processo simultâneo de irradiação, realizado no irradiador de ${ }^{60} \mathrm{Co}$ Gammacell, foram obtidos filmes de PETFE com grau de enxertia entre 5,0 e 15,4 \% (FIG. 28), com formação de homopolímeros e distribuição de enxertia heterogênea. Cabe ressaltar que, no caso de uso deste irradiador, o tempo de exposição foi elevado em função da baixa taxa de dose $\left(1 \mathrm{kGy} \cdot \mathrm{h}^{-1}\right)$.

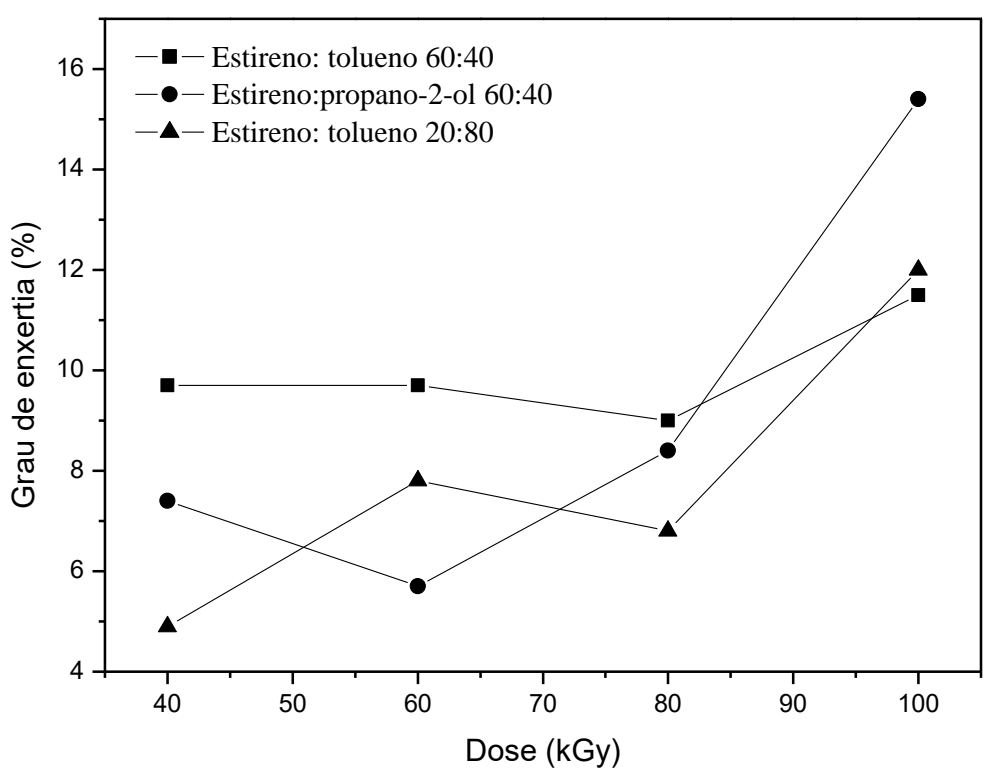

FIGURA 28 - Variação do grau de enxertia dos filmes de PETFE irradiados nas soluções de: (a) estireno:tolueno 60:40, v:v, (b) estireno:propano-2-ol 60:40, v:v, e (c) estireno:tolueno 20:80, v:v, em função da dose absorvida de radiação

Os efeitos da dose de radiação, concentração de monômero e tipo de solvente não ficaram claramente definidos devido à elevada formação de homopolímeros, observada principalmente nas doses acima de 80 kGy.

Os baixos valores de grau de enxertia e heterogeneidade da enxertia das amostras inviabilizam a síntese de membranas aniônicas para a aplicação em células alcalinas, e podem ser relacionados à menor susceptibilidade dos filmes de PETFE a formação de radiais devido a estabilidade das ligações C - F presentes na cadeia do polímero, e a homopolimerização do monômero de estireno.

Os filmes de PETFE produzidos pelo processo simultâneo de irradiação, utilizando-se 0 irradiador Multipropósito de ${ }^{60} \mathrm{Co}$, apresentaram graus de 
enxertia entre 1,5 e 15,6 \%, como pode ser observado na FIG. 29. No entanto, foram obtidos filmes mais homogêneos e com menor formação de homopolímeros que os obtidos no irradiador de ${ }^{60} \mathrm{Co}$ Gammacell, A taxa de dose do irradiador Multipropósito de ${ }^{60} \mathrm{Co}$ variou entre 8 e $11 \mathrm{kGy} \cdot \mathrm{h}^{-1}$ durante os testes. Estes resultados foram inferiores aos encontrados por MAMLOUK et al. (2012).

Segundo MAMLOUK et al (2012), o baixo grau de enxertia do polímero PETFE, apresentou DOG de $24 \%$, em emulsão aquosa de VBC, pode ser atribuído a características dos polímeros fluorados e semi-fluorados que exigem doses de radiação maiores nos processos de pré-irradiação e de irradiação simultânea para obter graus de enxertia semelhantes aos polímeros a base de hidrocarbonetos. Além das propriedades diferentes de massa molar e cristalinidade dos polímeros.

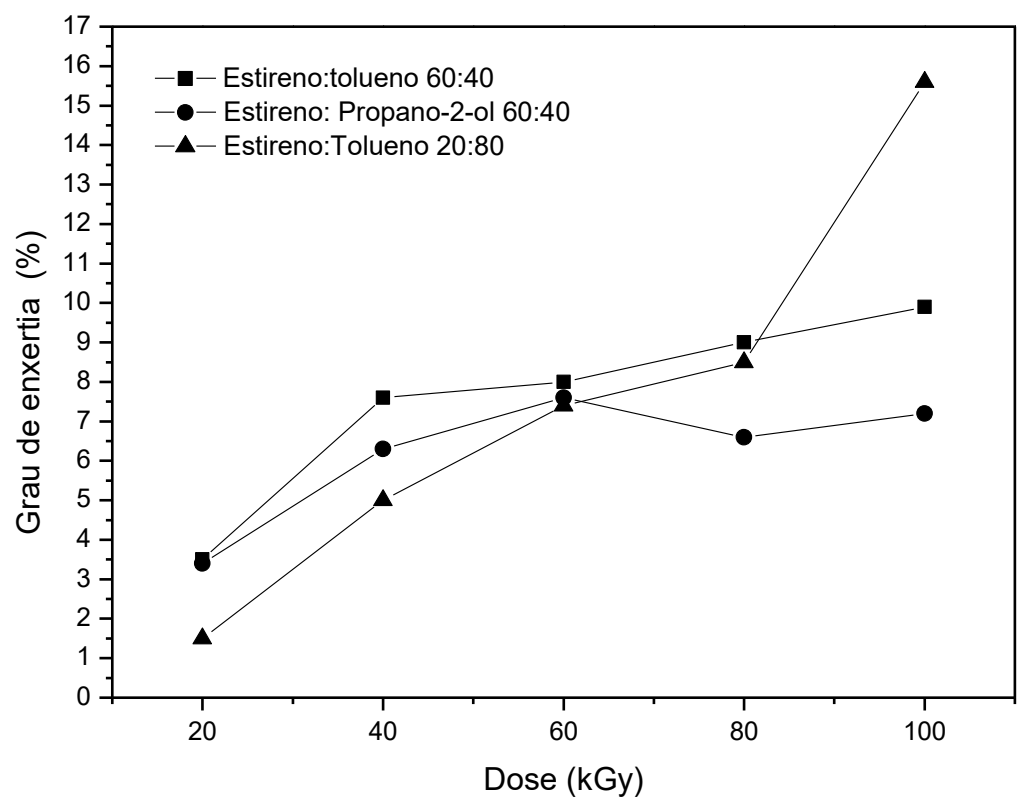

FIGURA 29 - Variação do grau de enxertia dos filmes de PETFE irradiados nas soluções de: (a) estireno:tolueno 60:40 ,v:v, (b) estireno:propano-2-ol 60:40 ,v:v, (c) estireno:tolueno 20:80,v:v, em função da dose absorvida de radiação

A variação nos graus de enxertia pode ser atribuída ao efeito do solvente, às propriedades de difusão do monômero e ao tempo de vida dos radicais (NASEF e HEGAZY, 2004). 
Embora os resultados de grau de enxertia (DOG) sejam insuficientes para a síntese de membranas aniônicas, é possível observar a influência, da dose absorvida de radiação, do solvente, e da concentração de monômero.

Observa-se uma tendência de aumento no DOG com o aumento da dose de radiação até dose de $60 \mathrm{kGy}$, a partir da qual, o grau de enxertia tende a estabilização (cerca de $8 \%$ ), exceto a solução estireno:tolueno $20: 80$, v:v, que apresentou o maior DOG em 100 kGy.

A variação na concentração de monômero e tipo de solvente influenciou de forma diferente os DOGs nas diferentes doses de radiação. Entre as doses 20 a 60 kGy, o grau de enxertia aumentou com o aumento da concentração de monômero nas diversas soluções, tendendo em seguida, a estabilização. A solução estireno:tolueno 20:80, v:v., exibiu o maior DOG em 100 kGy, porém com distribuição de enxertia heterogênea. As amostras irradiadas acima de 80 kGy apresentaram tendência crescente de homopolimerização e aumento da viscosidade da solução. POYTON e VARCOE (2015) sugeriram que esta tendência pode estar relacionada ao comportamento de intumescimento (do inglês, swelling) do PETFE durante a enxertia e com a disponibilidade de monômero para os sítios de enxertia formados no processo de irradiação. NASEF et al. (2008), observou que o intumescimento dos filmes de PETFE ocorreu de forma decrescente na seguinte ordem: toluol > dimetilformamida >> propano-2-ol, > etanol > metanol.

No caso especifico deste trabalho, os baixos valores de enxertia encontrados podem ter relação com a taxa de dose baixa do irradiador ( Gammacel (1,042 kGy.h $\left.{ }^{-1}\right)$ e Irradiador Multipropósito (8 - $\left.11 \mathrm{kGy} \cdot \mathrm{h}^{-1}\right)$, espessura do polímero $(125 \mu \mathrm{m})$, em geral, nas literaturas foram relatados estudos utlizando filmes com espessuras menores (25 - $50 \mu \mathrm{m})$, ou ainda resultante da formação de homopolímeros e reações de recombinação devido ao longo tempo de exposição. Estudo mais detalhado dos parâmetros de processo poderá ajudar na obtenção de enxertias mais uniformes. 


\subsubsection{Processo de pré-irradiação}

\subsubsection{Estabilidade dos radicais}

A estabilidade dos radicais de filmes de PETFE pré-irradiados a $70 \mathrm{kGy}$ no acelerador de elétrons ao ar e temperatura ambiente foi monitorada por EPR em duas etapas. Inicialmente, a estabilidade dos radicais foi avaliada em função do tempo e temperatura de armazenamento (ambiente e $-70 \pm 4 \stackrel{\circ}{\circ}$ ) durante dois meses. Em uma segunda etapa, o decaimento dos radicais foi monitorado durante 8 meses para avaliar o efeito do tempo de armazenamento a baixas temperaturas $(-70 \pm 4 \stackrel{\circ}{\circ})$ no desempenho da membrana.

A estabilidade dos radicais formados após a irradiação dos filmes de PETFE foram caracterizados pela variação da intensidade dos sinais de EPR dos diferentes tipos de macroradicais formados durante o processo de irradiação em função do tempo de armazenamento a baixa temperatura e pelo fator $g$ calculado por meio da Eq. 27.

O decaimento dos radicais em função do tempo de armazenamento a baixas temperaturas foram estimados pela variação da amplitude do sinal de EPR pico-a-pico normalizado dos radicais peroxila (pico central predominante)

Durante a irradiação de filmes de PETFE, podem ser gerados pelo menos dois tipos de radicais: peroxila $(\mathrm{ROO} \cdot)$, $\left(\mathrm{P}_{1}\right)$, e aquila $\left(-\mathrm{CH}_{3} \mathrm{C} \cdot \mathrm{HCF}_{2} \mathrm{CF}_{2}\right)\left(\mathrm{P}_{2}\right)$ e $\left(\mathrm{P}_{3}\right)$, dependendo da atmosfera presente durante a irradiação (nitrogênio e ar, respectivamente) (MITOV et al., 2006; LARSEN et al, 2010).

Nas FIG. 30 e 32 são mostradas a variação da intensidade dos sinais de EPR formados durante o processo de pré-irradiação dos filmes pré-irradiados de PETFE armazenados a temperatura ambiente e a baixa temperatura.

Os espectros das amostras mantidas a temperatura ambiente (FIG. 30) indicaram a presença de radicais peroxila $g=2,0181$ (campo magnético 345 $355 \mathrm{mT}$ ) e radicais alquila $g=1,9944$ e $g=1,9765$ (campo magnético 353 $355 \mathrm{mT}$ ). Após sete dias, observou-se o predomínio de radicais peroxila ( $g=$ 2,0196). $O$ valor de $g$ permaneceu constante até 2 meses após a irradiação, 
indicando a presença de radicais peroxila. Resultados similares foram encontrados na literatura (MITOV et al., 2006; LARSEN et al, 2010).

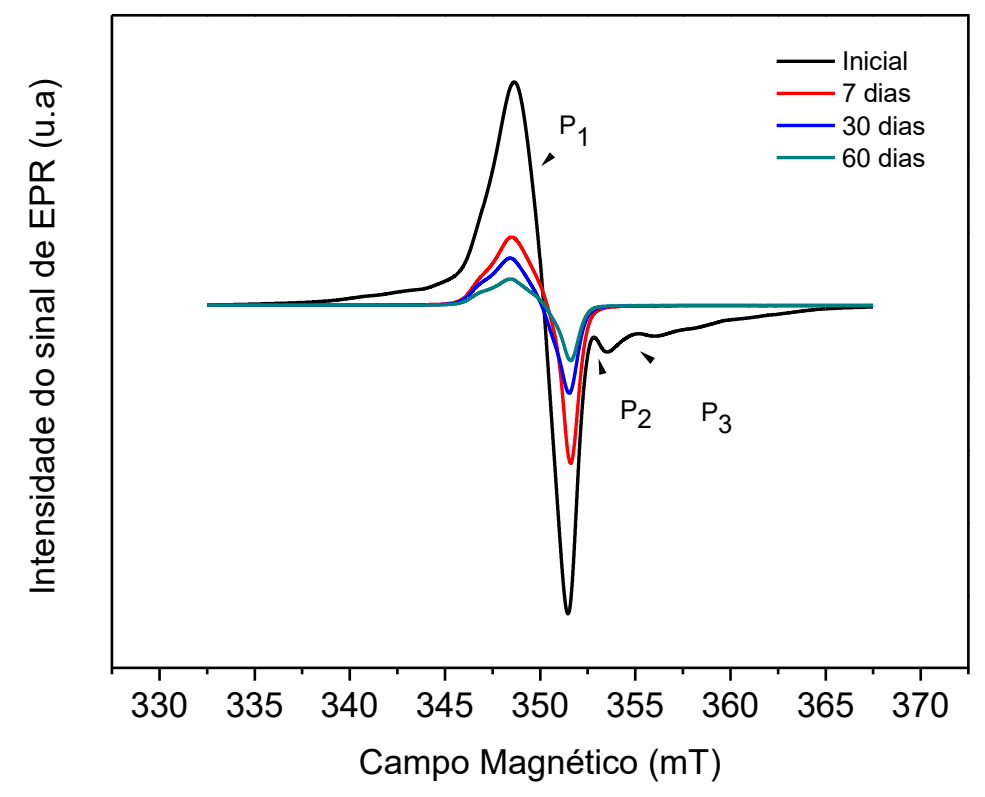

FIGURA 30 - Espectros EPR de filmes de PETFE pré-irradiados a 70 kGy com feixe de elétrons e mantido a temperatura ambiente durante 60 dias, irradiados e medidos a temperatura ambiente.

A análise do decaimento dos radicais peroxila dos polímeros de PETFE, em função do tempo de armazenamento a $\left(-70 \pm 4^{\circ} \mathrm{C}\right)$, seguiram um ajuste exponencial (FIG. 31). O PETFE apresentou um decaimento de $85 \%$ dos radicais na forma peroxila após 30 dias (Eq. 33). Resultados similares foram encontrados na literatura (MITOV et al., 2006; LARSEN et al., 2010).

$$
y=1,84 E 9^{*} \exp (-x / 5,68)+4,44, R^{2}=0,95814
$$




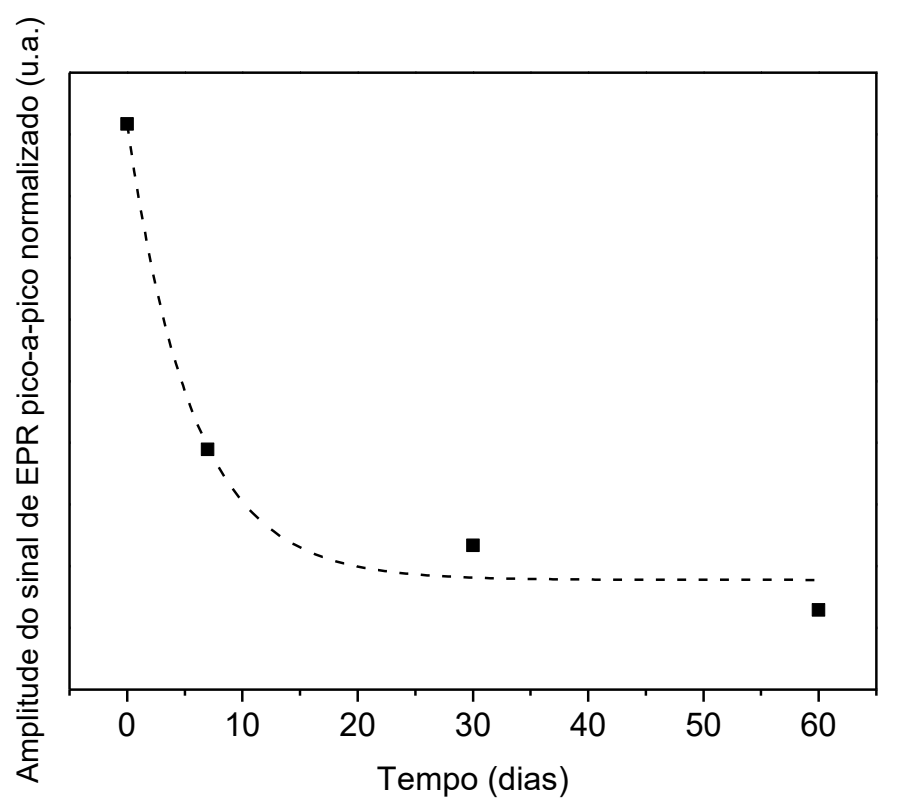

Figura 31 - Amplitude do sinal EPR pico-a-pico normalizado versus tempo de armazenamento a baixa temperatura $\left(-70 \pm 4^{\circ} \mathrm{C}\right)$ em dias dos filmes de PETFE, préirradiados a $70 \mathrm{kGy}$ e armazenados a baixa temperatura $\left(-70 \pm 4{ }^{\circ} \mathrm{C}\right)$ durante 180 dias medidos e irradiados a temperatura ambiente.

A variação da intensidade dos sinais de EPR das amostras pré-irradiadas de PETFE mantidas a baixa temperatura foi monitorada durante 240 dias (FIG. 32). Os resultados indicaram a presença predominantemente de radicais peroxila $(g=2,0188)$. $O$ fator $g$ permaneceu constante indicando os radicais foram preservados por até 240 dias quando mantidos a $-70 \pm 4{ }^{\circ} \mathrm{C}(g=2,0188)$. Resultados similares foram encontrados na literatura (MITOV et al., 2006; LARSEN et al., 2010). 


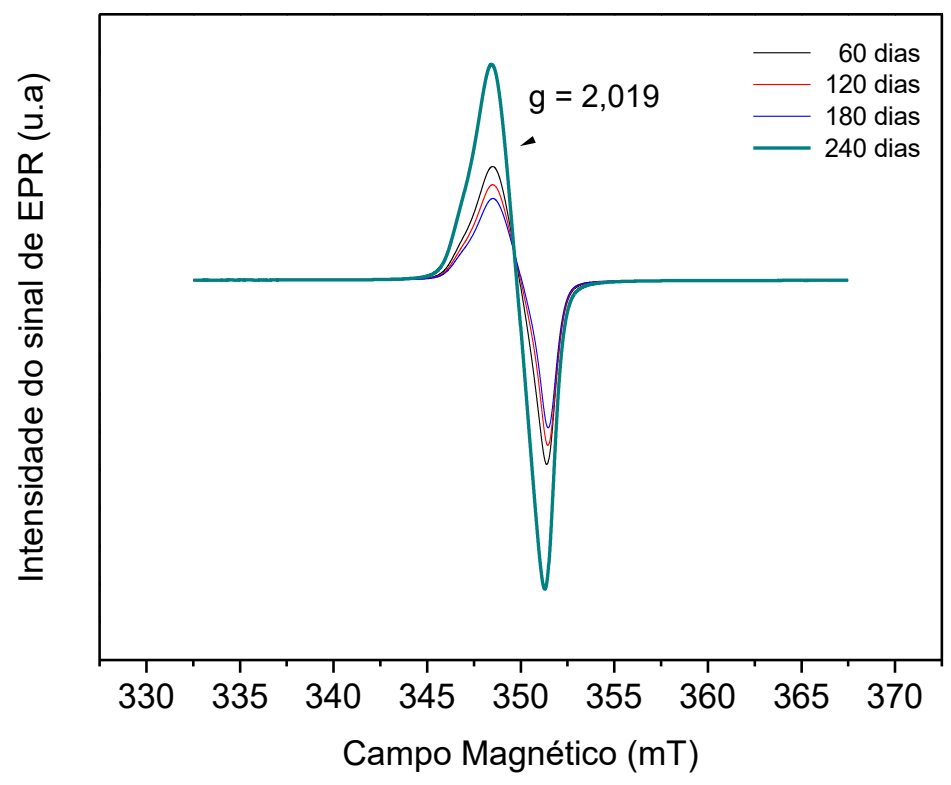

FIGURA 32 - Espectros EPR de filmes de PETFE pré-irradiados a 70 kGy e mantidos a baixa temperatura $\left(70 \pm 4^{\circ} \mathrm{C}\right.$ ) durante 240 dias, irradiados e medidos a temperatura ambiente.

A análise do decaimento dos radicais peroxila dos polímeros de PETFE, em função do tempo de armazenamento a baixa temperatura $\left(-70 \pm 4^{\circ} \mathrm{C}\right)$, seguiram um ajuste exponencial (FIG. 33). O PETFE apresentou um decaimento inferior que as amostras mantidas a temperatura ambiente, após 30 e 60 dias, o decaimento foi de $39 \%$ e $59 \%$, respectivamente O decaimento dos radicais peroxila seguiu um ajuste exponencial (Eq. 33). Resultados similares foram encontrados na literatura (MITOV et al., 2006; LARSEN et al, 2010).

$$
y=5,71 E 13^{*} \exp (-x / 83,0)+2,17, R^{2}=0,9955
$$




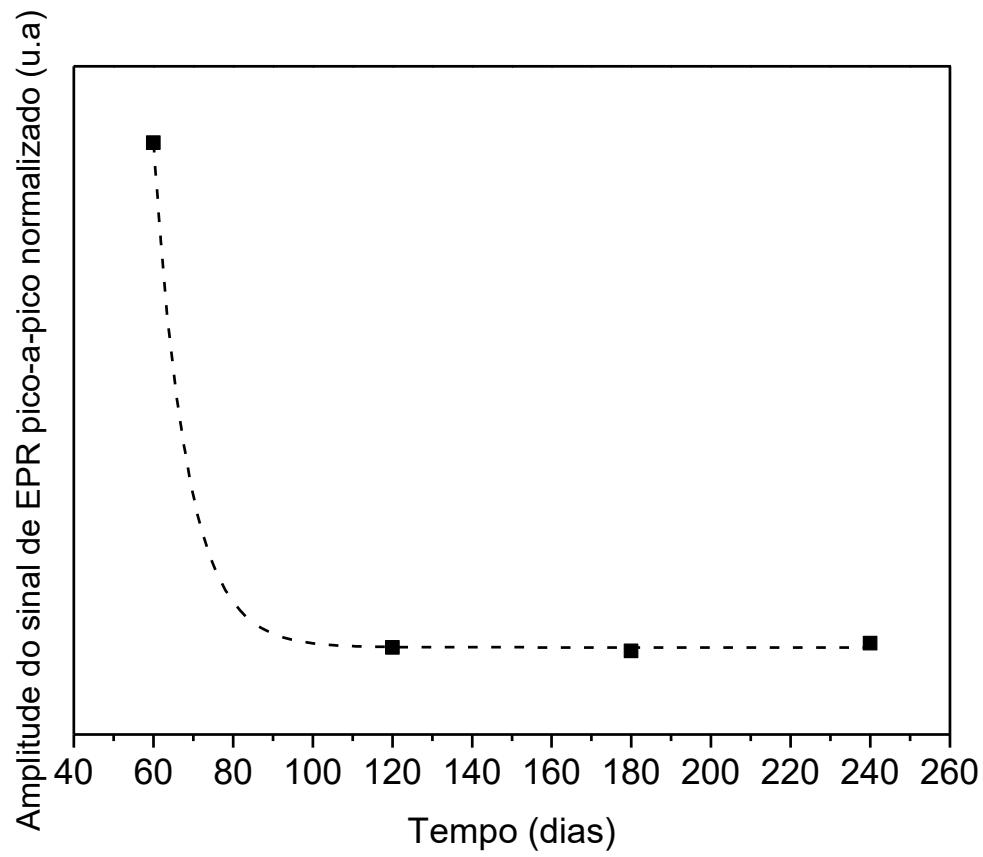

Figura 33 - Amplitude do sinal EPR pico-a-pico normalizado versus tempo de armazenamento a baixa temperatura $\left(-70 \pm 4{ }^{\circ} \mathrm{C}\right)$ em dias dos filmes de LDPE e UHMWPE, pré-irradiados a $70 \mathrm{kGy}$ e armazenados a baixa temperatura $(-70 \pm 4 \stackrel{\circ}{\circ})$ durante 180 dias, irradiados e medidos a temperatura ambiente.

A estabilidade dos radicais peroxila foi muito influenciada pela temperatura e pelo tempo de armazenamento. Em temperatura ambiente 0 sinal de intensidade decaiu $85 \%$ após 30 dias, enquanto em baixa temperatura os decaimentos, após 30 e 60 dias, foram de $39 \%$ e $59 \%$ respectivamente.

\subsubsection{Caracterização DOG, IEC e WU}

Na TAB. 8 são apresentados os valores de DOG, WU e IEC para as membranas sintetizadas com os filmes PETFE $(125 \mu \mathrm{m})$ pré-irradiados e armazenados em baixas temperaturas durante 2 e 10 meses para avaliar a influência do tempo de armazenamento no desempenho da AEMFC. A enxertia foi realizada em solução de monômero de estireno: propano-2-ol (60:40 v:v). a temperatura ambiente por 24 horas. Foram apresentados os resultados após a reação de sulfonação em solução de ácido clorossulfônico em 1,2 dicloroetano 
0,2 M, e após a reação de alquilação em solução de solução aquosa de hidróxido de potássio $1 \mathrm{~mol} \mathrm{~L}^{-1}$.

TABELA 8- Resultados de DOG, IEC, WU das membranas de ETFE em função do tempo de armazenamento dos filmes a $-70 \pm 4 \stackrel{\circ}{\circ} \mathrm{C}$ ( 2 e 10 meses)

\begin{tabular}{cccccccc}
\hline Membrana & $\begin{array}{c}\text { Tempo de } \\
\text { armazenamento } \\
(-70 \pm 4 \stackrel{\circ}{ }-\mathrm{C}) \\
(\mathrm{meses})\end{array}$ & $\begin{array}{c}\text { DOG } \\
(\%)\end{array}$ & $\begin{array}{c}\text { IEC sulfonação } \\
\left(\mathrm{m} \mathrm{molg}^{-1}\right)\end{array}$ & $\begin{array}{c}\text { Espessura } \\
\text { úmida } \\
(\mu \mathrm{m})\end{array}$ & $\begin{array}{c}\text { WU } \\
(\%)\end{array}$ & $\begin{array}{c}\lambda \\
{\left[\mathrm{mol}\left(\mathrm{H}_{2} \mathrm{O}\right) /\right.} \\
\mathrm{mol}(\mathrm{OH}-)]\end{array}$ & $\begin{array}{c}\text { IEC } \\
\left(\mathrm{m} \mathrm{molg}^{-1}\right)\end{array}$ \\
\hline ETFE-EB-70-2 $\mathrm{m}$ & 2 & $78 \pm 7,6$ & $0,820 \pm 0.03$ & $298 \pm 0,01$ & $122 \pm 15$ & 0,034 & $1,980 \pm 0.015$ \\
ETFE-EB-70-10 $\mathrm{m}$ & 10 & $114 \pm 18$ & $2,540 \pm 0.07$ & $319 \pm 0,09$ & $141 \pm 25$ & 0,103 & $0,760 \pm 0.050$ \\
\hline
\end{tabular}

Os resultados de DOG sugerem que os radicais gerados na irradiação foram preservados após 10 meses a $-70 \pm 4 \stackrel{\circ}{ } \mathrm{C}$. Estes valores ficaram próximos aos reportados por MITOV et al (2006). A diferença entre os valores de DOG para as membranas após 2 e 10 meses indica, provavelmente, que os filmes resultantes são heterogêneos. Para ambas as membranas, observa-se uma elevada capacidade de absorção de água (WU) e $\lambda$.

A capacidade de troca iônica (IEC) é uma indicação da quantidade de grupos amônio quaternários disponíveis para a troca iônica na membrana. Muito embora IEC, DOG e WU tenham, aparentemente, uma correlação linear e direta (FANG et al., 2012), uma vez que o transporte de íons $\mathrm{OH}^{-}$depende do número de grupos funcionais e também da quantidade de água (transportador de água), os resultados de IEC das membranas de PETFE após 2 e 10 meses não seguiram esta tendência, sugerindo uma correlação com os elevados valores de WU obtidos na etapa de sulfonação.

\subsubsection{Microscopia de varredura (MEV)}

A FIG. 34 mostra as imagens MEV para os filmes de PETFE préirradiados a 70kGy em acelerador de elétrons, enxertados com monômero de estireno e armazenado a baixa temperatura após 2 e 10 meses (FIG.34-a e 34b), e as membranas na forma OH- (FIG.34-c e 34-d). 

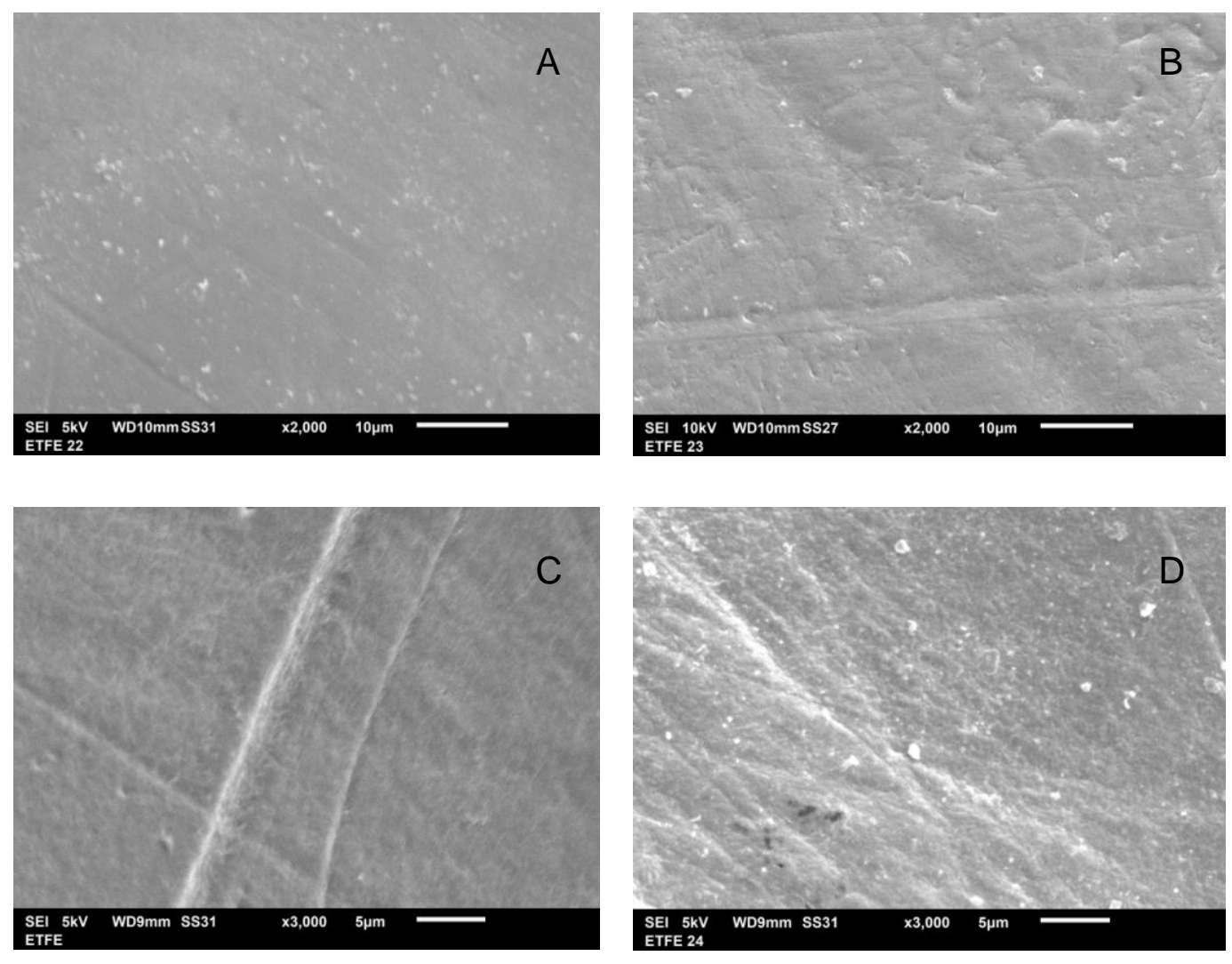

FIGURA 34 - Imagens MEV dos filmes e membranas de PETFE: Filmes de PETFE pré-irradiados a $70 \mathrm{kGy}$ ao ar e temperatura ambiente mantidos a baixa temperatura ($70 \pm 4$ C ): (A) PETFE $2 \mathrm{~m}$ - após 2 meses, (B): PETFE- $10 \mathrm{~m}$ - após 10 meses. Membranas de PETFE na forma $\left(\mathrm{OH}^{-}\right)$; (C) MEA $2 \mathrm{~m}$ - sintetizadas após 2 meses e (D)- MEA - 10 m - sintetizadas após 10 meses. Ampliação 3000 x.

As imagens dos filmes de PETFE enxertados com monômero de estireno após 2 e 10 meses de armazenamento a baixas temperaturas sugerem uma morfologia semelhante e dependente do DOG. A amostra com maior grau de enxertia e maior tempo de armazenamento a baixa temperatura apresentou uma superfície com distribuição de enxertia mais irregular.

As imagens das membranas de PETFE (na forma $\mathrm{OH}-$ ) mostraram alterações na morfologia em função da capacidade de absorção de água, evidenciando a manutenção da estrutura os filmes após enxertia. A membrana com maior WU e intumescimento apresentou regiões com maior irregularidade. 


\subsubsection{Espectroscopia Raman}

A espectroscopia Raman foi utilizada para a caracterização da composição química do filme de PETFE (não irradiado), filme de PETFE irradiado em feixe de elétrons a $70 \mathrm{kGy}$ a temperatura ambiente na presença de ar e enxertada (solução estireno:propano-2-ol 60:40 (v:v); 24 horas a 60ํㅡ) e armazenada a baixa temperatura por 10 meses, e a membrana final após quaternização com trimetilamina (45\%, solução aquosa). Na FIG. 35 são mostrados os espectros Raman das amostras de PETFE.

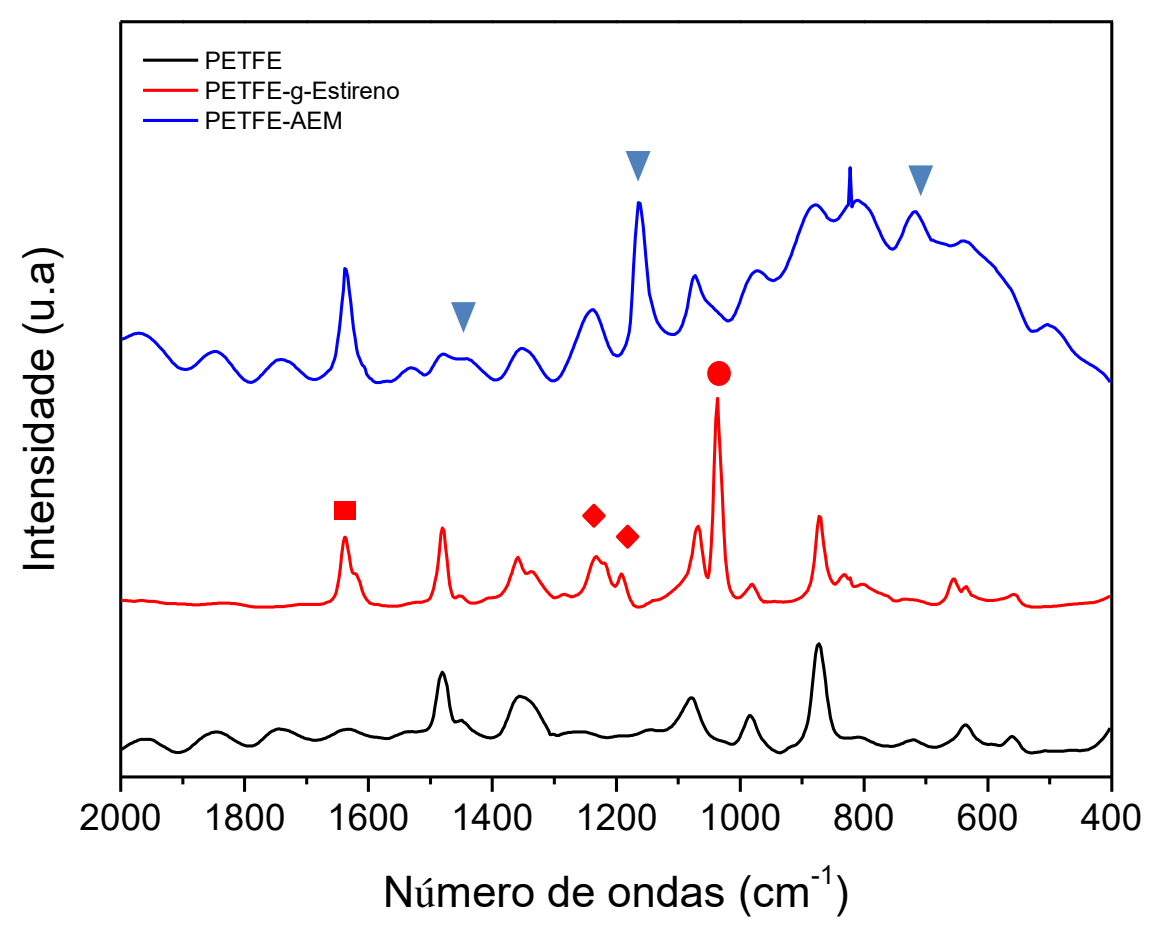

FIGURA 35 - Espectro Raman do PETFE não-irradiado (PETFE), PETFE após enxertia com solução monômero de estireno: propano-2-ol (60:40 v:v) (PETFE-gEstireno), e membrana de troca aniônica de PETFE na forma (OH) (AEM) (após 10 meses a $-70 \pm 4{ }^{\circ} \mathrm{C}$ ). $\mathrm{O}$ espectro foi obtido no intervalo de $400-2000 \mathrm{~cm}^{-1}$, laser $532 \mathrm{~nm}$.

O espectro dos filmes de PETFE (não irradiados) contem os estiramentos $\mathrm{CF}_{2}$ (1352 e $\left.1363 \mathrm{~cm}^{-1}\right)$ e $\mathrm{CH}_{2}\left(1449 \mathrm{~cm}^{-1}\right)$. Após a reação de enxertia a amostra apresentou novos estiramentos correspondentes ao monômero de estireno, anel aromático $\left(1617 \mathrm{~cm}^{-1}, \mathbf{n}\right.$, e $\left.1041 \mathrm{~cm}^{-1}, \bullet\right)$; C-C aromático (1225 a 
$1191 \mathrm{~cm}^{-1}, \diamond$ ), confirmaram a enxertia das cadeias de poliestireno, indicando a presença dos grupos estireno na estrutura do polímero base após o processo de enxertia. O espectro Raman da amostra ao final da reação de quaternização com TMA apresentou os estiramentos C-N $\left(723 \mathrm{~cm}^{-1}, 1161 \mathrm{~cm}^{-1}\right.$, e $1477 \mathrm{~cm}^{-1}$, V) indicando a presença de grupos de amônio quaternário $\left(-\mathrm{N}^{+}\left(\mathrm{CH}_{3}\right)_{3}\right)$. Resultados similares/semelhante foram encontrados por SARAH et al. (2014); POYNTON e VARCOE (2015); GONZALEZ et al. (2016).

\subsubsection{Termogravimetria}

A estabilidade térmica e os perfis de decomposição dos filmes de PETFE não irradiados, PETFE pré-irradiados a 70 kGy e enxertados com monômero de estireno (solução 60:40 estireno:propano-2-ol, v:v) após armazenamento em baixa temperatura $\left(-70 \pm 4{ }^{\circ} \mathrm{C}\right)$ durante 2 e 10 meses, e as membranas aniônicas (na forma $\mathrm{OH}^{-}$) foram avaliadas comparativamente. As curvas de perda de massa (TG) e sua derivada primeira (DTG) mostradas na FIG. 36 

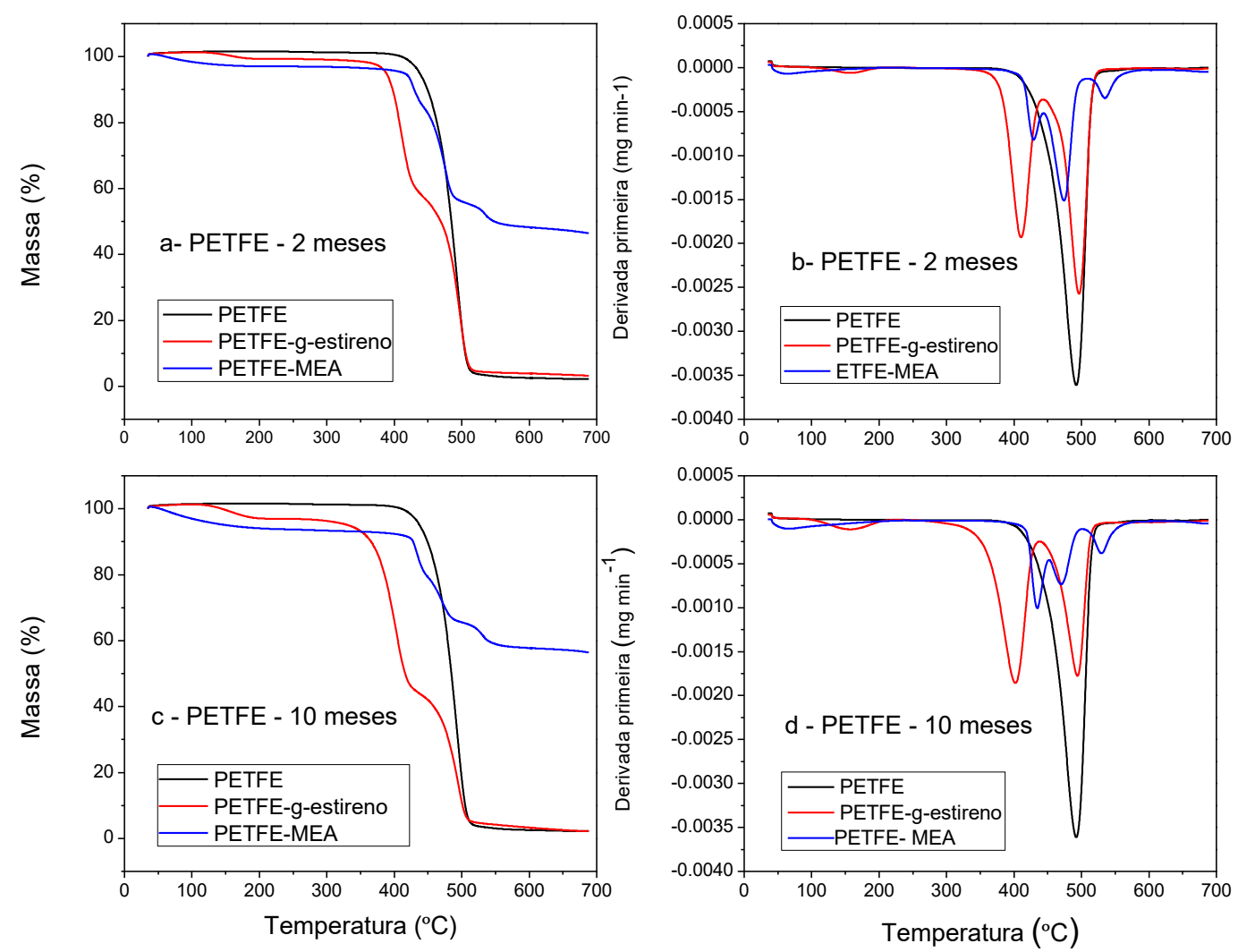

FIGURA 36 - Curvas TG: (a) e (c); DTG (b) e (d) das amostras após 2 e 10 meses (2m e 10 m): (a) PETFE não irradiadas, PETFE pré-irradiada em feixe de elétrons a 70 kGy e enxertadas com estireno (solução 60:40 estireno: propano-2-ol, v:v),e membrana aniônica na forma (OH-) obtidas a $10^{\circ} \mathrm{C} \mathrm{min}^{-1}$ e sob atmosfera de $\mathrm{N}_{2}$.

No filme de PETFE não irradiados foi observado um único evento de perda de na temperatura de aproximadamente $500{ }^{\circ} \mathrm{C}$ atribuído à degradação da cadeia principal do polímero de PETFE com 98\% de perda de massa (FANG et al., 2012; KO et al., 2012; POYTON e VARCOE, 2015).

Perfis de degradação semelhantes foram observados nos filmes de PETFE enxertados após 2 e 10 meses de armazenamento a baixa temperatura. A presença de poliestireno enxertado nos filmes de PETFE não alterou a temperatura de decomposição do polímero base e os filmes de PETFE enxertados após 2 e 10 meses de armazenamento a baixa temperatura mostraram um evento adicional atribuído à degradação do monômero de 
estireno enxertado, e uma ligeira redução na estabilidade térmica com perdas de massa iniciando respectivamente nas temperaturas de $410^{\circ} \mathrm{C}$ (FIG. 36-a) e $400 \stackrel{\circ}{\circ}$ (FIG. 36- c). Comportamento semelhante foi relatado na literatura (FANG, et al., 2012; KO et al., 2012; POYTON e VARCOE, 2015). Uma etapa de evaporação de compostos voláteis foi observada na faixa de temperatura entre 30 e $230^{\circ} \mathrm{C}$, mais acentuada na amostra enxertada após 10 meses. A segunda etapa de degradação da cadeia dos polímeros PETFE enxertados após 2 meses e 10 meses ocorreu em $500 \stackrel{\circ}{\circ}$ (FIG. 36-a e 36-C), com perdas de massa de $97 \%$ e $98 \%$,respectivamente. Perdas de massa semelhantes foram obtidas por (FANG et al., 2012; KO et al., 2012; POYTON e VARCOE, 2015).

Nas membranas de PETFE na forma $\left(\mathrm{OH}^{-}\right)$sintetizadas com os filmes enxertados após 2 e 10 meses de armazenamento a baixas temperaturas, a perda de massa ocorreu gradativamente até a temperaturas de $420 \stackrel{\circ}{\circ}$ (FIG. 36-a e 36-c) onde iniciou a decomposição do monômero de estireno enxertado e da cadeia de PETFE. A perda de massa inicial até $230 \stackrel{\circ}{\circ}$ pode ser associada à evaporação de água, solventes orgânicos, monômeros, grupos de amônio, quaternário e grupos sulfônicos indicando um comportamento de retenção de água em temperaturas adequadas para aplicação em AEMFC. A decomposição do monômero enxertado e da cadeia do polímero de PETFE ocorreu em $470 \stackrel{\circ}{\circ}$ (FIG. 36-a e 36-C). A etapa final de decomposição da cadeia principal do polímero de PETFE ocorreu $540^{\circ} \mathrm{C}$ e (FIG 36-a e 36-C) com perdas de massa de $54 \%$ e $44 \%$ respectivamente. Os resíduos podem ser atribuídos a presença de resíduos de enxofre, óxidos e alguma substância inorgânica formada durante a reação de enxertia. Os resíduos não foram analisados. Perdas de massa semelhantes foram obtidas na literatura (FANG et al., 2012; KO et al., 2012; POYTON e VARCOE, 2015). A temperatura de termino do estudo de degradação ocorreu em $700 \stackrel{\circ}{\circ}$. 
Os resultados de temperaturas de início de decomposição térmica observadas para as membranas de PETFE na forma $\left(\mathrm{OH}^{-}\right)$sintetizadas com os filmes enxertados após 2 de 10 meses de armazenamento abaixas temperaturas observadas na temperatura de $420{ }^{\circ} \mathrm{C}$ (FIG. 36-a e 36-c), indicando que estas membranas possuem estabilidade térmica adequada para a aplicação em célula a combustível alcalina. Perdas de massa semelhantes foram previamente relatados por SHEARAZI et al. (2009) e MAURYA et al. (2013).

Nas membranas na forma $\mathrm{OH}^{-}$dos polímeros enxertados após 2 e 10 meses de armazenamento a baixa temperatura, foram observados uma tendência de aumento da massa de água eliminada, e aumento da estabilidade térmica com o aumento do DOG, IEC da reação de sulfonação, e WU.

\subsubsection{Espectroscopia de impedância}

Na FIG. 37, são mostrados os valores de condutividade das membranas sintetizadas com filmes de PETFE pré-irradiados a $70 \mathrm{kGy}$ e enxertados com monômero de estireno (solução 60:40 estireno:propano-2-ol, v:v) após 2 e 10 meses de armazenamento em baixa temperatura $(-70 \pm 4 \stackrel{\circ}{ } \mathrm{C})$.

Os dados obtidos mostraram uma tendência de aumento de condutividade com a temperatura, com valor máximo de $100 \mathrm{mS} \mathrm{cm}^{-1}$ à $80 \stackrel{\circ}{\circ} \mathrm{C}$ para a membrana de PETFE após 2 meses. Esse valor de condutividade pode ser considerado bastante elevado, sendo comparável, inclusive, aos valores de condutividade obtidos para as membranas trocadoras de prótons (p. ex. Nafion $^{\mathrm{TM}}$ ) empregadas em PEMFCs.

A comparação do PETFE pré-irradiado e armazenado por 2 e 10 meses mostra que a condutividade não segue a correlação linear de aumento com os valores de DOG,IEC e WU, provavelmente em função do alto valor de WU.

KIZEWSKI et al. ( 2013) sintetizaram membranas com filmes de PETFE $(50 \mu \mathrm{m})$ pré-irradiados armazenados a baixa temperatura $(-36 \pm 2 \stackrel{\circ}{\circ})$ por até 
16 meses com IEC 1,0 - 1,8 $\mathrm{mmol} \mathrm{g}^{-1}$ e condutividade iônica cerca de $20-40$ $\mathrm{mS} \mathrm{cm}{ }^{-1}$ a temperatura ambiente.

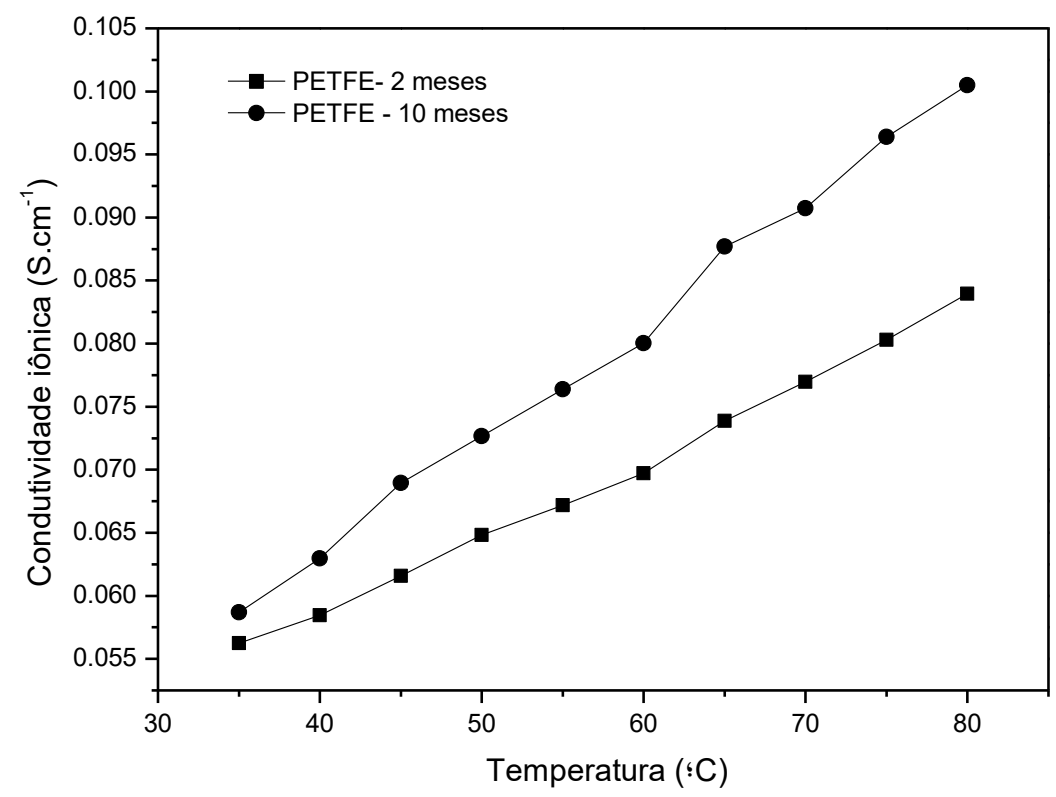

FIGURA 37 - Condutividade aniônica das membranas aniônicas hidratadas na forma $\left(\mathrm{OH}^{-}\right)$do polímero de PETFE sintetizadas após 2 e 10 meses de armazenamento a $70 \pm 4^{\circ} \mathrm{C}$ em $\mathrm{RH}=100 \%$. Medidas em $\mathrm{RH}=100 \%, 2$ pontas, faixa de frequência de $30 \mathrm{MHz}$ a $0,1 \mathrm{~Hz}$.

No gráfico de Arrhenius das membranas de PETFE após 2 e 10 meses de armazenamento a baixa temperatura $\left(70 \pm 4^{\circ} \mathrm{C}\right)$, mostrados na FIG. 38, observou-se que as resistências das membranas diminuem gradativamente com o aumento da temperatura. As energias de ativação, Ea, estimadas utilizando a equação de Arrhenius (Eq. 30) das membranas de PETFE na forma $\left(\mathrm{OH}^{-}\right)$, após 2 e 10 meses, foram de $10,76 \mathrm{~kJ} \mathrm{~mol}^{-1}$ e $8,11 \mathrm{~kJ} \mathrm{~mol}^{-1}$, respectivamente. 
$\mathrm{T}(\lfloor\mathrm{C}) 80-35$

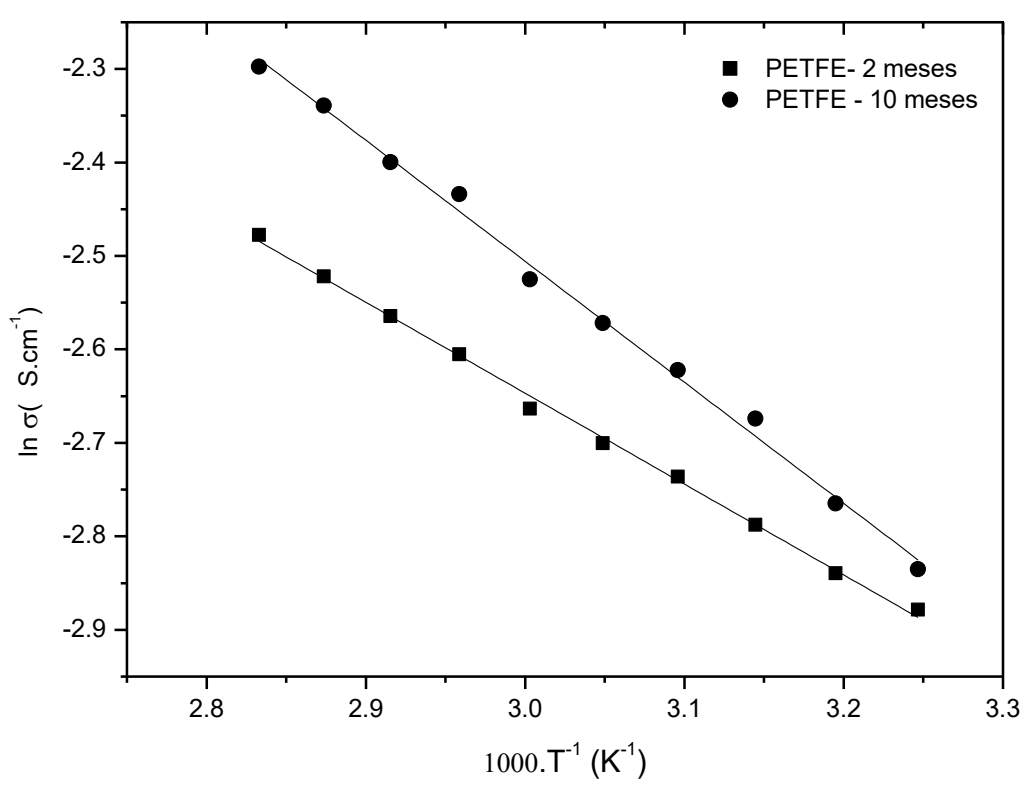

FIGURA 38 - Gráfico de Arrhenius das membranas aniônicas do polímero de PETFE hidratadas na forma $\left(\mathrm{OH}^{-}\right)$sintetizadas após 2 e 10 meses.

A energia de ativação, Ea, está relacionada à barreira energética para a migração de íons de um ponto para outro com base no mecanismo Grotthus (JEONG et.al., 2015). O transporte dos íons $\mathrm{OH}^{-}$é facilitado quando a energia de ativação é baixa (JEONG et al., 2015; MAMLOUK e SCOTT, 2012). A membrana após 10 meses, com menor energia de ativação, exibiu a maior condutividade iônica.

Estes resultados de energia de ativação foram superiores ao reportado por VARCOE et al. (2007), que sintetizaram membranas PETFE (50 $\mu \mathrm{m})$ enxertadas com VBC e funcionalizadas com TMA com condutividade iônica cerca de $34 \mathrm{mS} \mathrm{cm}^{-1}$ a $50 \stackrel{\circ}{\mathrm{C}}$ como consequência da menor energia de ativação, $\mathrm{E}_{\mathrm{a}}$, cerca de $6,20 \mathrm{~kJ} \mathrm{~mol}^{-1}$, valor próximo ao Nafion ${ }^{\mathrm{TM}} 115$ cerca de $7,1 \mathrm{~kJ} \mathrm{~mol}^{-1}$.

Os valores de condutividade obtidos indicaram que as membranas sintetizadas com filmes pré-irradiados PETFE armazenados por até 10 meses 
a baixa temperatura podem ser empregados como eletrólitos em células a combustível alcalina ser aplicação em células a combustível.

Segungo LIU et al. (2011), observou o tempo de estabilização e recombinação dos radicais peróxidos no processo de preparação das membranas podem influenciar nos valores condutividade iônica e energia de ativação.

\subsubsection{Otimização do processo}

Com a finalidade de otimizar os parâmetros de processo e a reprodutibilidade dos resultados foi realizada em uma segunda etapa, um estudo do efeito das variáveis dose de radiação e tempo de armazenamento a baixa temperatura nas propriedades finais das membranas (TAB. 9).

As membranas foram preparadas com filmes PETFE pré-irradiados em feixe de elétrons nas doses 70 e 100 kGy, mantidos em baixa temperatura por até 9 meses. A enxertia dos filmes de PETFE, com diferentes tempos de armazenamento imediatamente após a irradiação ( $\mathrm{t}=0$ dias), e após nove meses a baixas temperaturas ( $t=270$ dias), foi realizada em solução de monômero de estireno e propano-2-ol na relação 60:40 em volume por 24 horas a $60^{\circ} \mathrm{C}$.

As amostras foram sintetizadas e caracterizadas por espectroscopia de ressonância paramagnética eletrônica (EPR), grau de enxertia, capacidade de troca iônica (IEC) e impedância eletroquímica. 
TABELA 9 - Parâmetros do processo de síntese das membranas do polímero de PETFE

\begin{tabular}{ccc}
\hline Amostras & $\begin{array}{c}\text { Dose de Irradiação } \\
(\mathrm{kGy})\end{array}$ & $\begin{array}{c}\text { Tempo de armazenamento } \\
\text { (dias) }\end{array}$ \\
\hline AM\#1 & 70 & 0 \\
AM\#2 & 100 & 0 \\
AM\#3 & 100 & 270 \\
AM\#4 & 70 & 270 \\
\hline
\end{tabular}

\subsection{Estabilidade dos radicais EPR}

No espectro de EPR dos PETFE pré-irradiados a $70 \stackrel{\circ}{\mathrm{C}}$ em acelerador de elétrons das amostras AM\#1, AM\#2, AM\#3 e AM\#4 (FIG. 39), foi possível observar a predominância de sinais equivalentes aos radicais peroxila (ROO), com fator $g$, estimados utilizando a EQ. 27, g=2,003 (campo magnético 353 $\mathrm{mT}$ ). Estes valores são próximos aos reportados por FEL et al. (2015), BUTTAFAVA, (2007), e por ALBANO et al (2003), respeitando os diferentes parâmetros definidos na análise de EPR.

A variação da intensidade de sinal de EPR nas amostras AM\#1, AM\#2, AM\#3 e AM\#4 foi fortemente influenciada pelos parâmetros de dose de radiação e tempo de armazenamento. Intensidades de sinal de EPR maiores foram observadas nos filmes de PETFE pré-irradiados nas condições de alta dose (100 kGy) e tempo curto de armazenamento $(t=0)$, sugerindo a formação de um elevado número de radicais imediatamente após a irradiação. Nas amostras analisadas após 270 dias, observou-se uma diminuição significativa do número de radicais, como consequência das reações de recombinação. GUILMEAU et al. (1997), observou que a intensidade dos sinais peroxila decaem, sem que haja alteração na forma do espectro EPR, por meio de reações recombinação (EQ.35) ou propagação (EQ.36). Na ausência de radicais alquila a Eq. 36 pode ser negligenciada: 
Recombinação

$$
\mathrm{ROO}+\mathrm{ROO} \rightarrow \mathrm{ROOR}+\mathrm{O}_{2}
$$

Propagação

$$
\mathrm{ROO}+\mathrm{PH} \rightarrow \mathrm{ROOH}+\mathrm{P} .
$$

ROO., macroradical peroxil gerado no momento da irradiação ao ar, $\mathrm{PH}$, cadeia do polímero, $\mathrm{P} \cdot$, radical alquila.

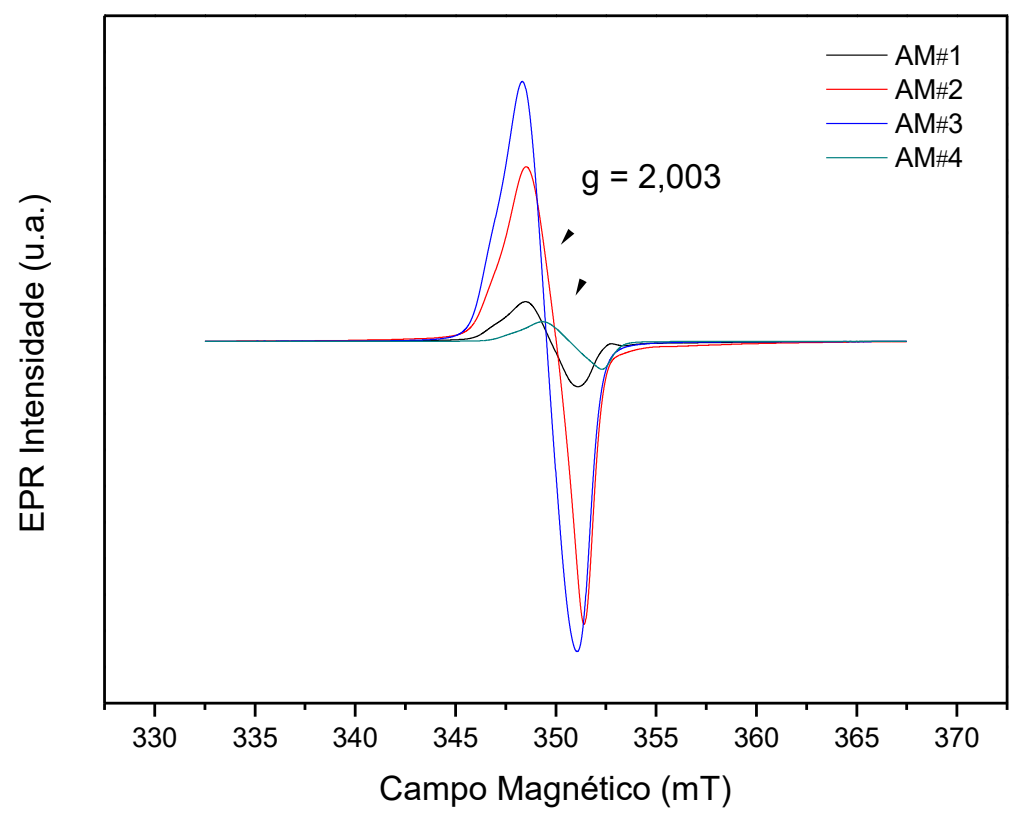

FIGURA 39 - Espectros EPR dos filmes de ETFE pré-irradiados a 70 e 100 kGy em função do tempo de armazenamento a $-70 \pm 4{ }^{\circ} \mathrm{C}$ ( 0 e 270 dias)

\subsection{Caracterização DOG, IEC e WU}

Os resultados de grau de enxertia, capacidade de absorção de água e capacidade de troca iônica das amostras estão apresentados na TAB. 10. 
TABELA 10 - Resultados de DOG, IEC e WU das membranas de PETFE em função da dose de radiação e tempo de armazenamento a $-70 \pm 4{ }^{\circ} \mathrm{C}$

\begin{tabular}{cccccccc}
\hline Amostra & $\begin{array}{c}\text { Dose } \\
(\mathrm{kGy})\end{array}$ & $\begin{array}{c}\text { Tempo } \\
(\mathrm{dias})\end{array}$ & $\begin{array}{c}\text { DOG } \\
(\%)\end{array}$ & $\begin{array}{c}\text { IEC sulfonação } \\
\left(\mathrm{m} \mathrm{molg}^{-1}\right)\end{array}$ & $\begin{array}{c}\text { WU } \\
(\%)\end{array}$ & $\begin{array}{c}\lambda \\
{\left[\mathrm{mol}\left(\mathrm{H}_{2} \mathrm{O}\right) /\right.} \\
\mathrm{mol}(\mathrm{OH}-)]\end{array}$ & $\begin{array}{c}\text { IEC } \\
\left(\mathrm{m} \mathrm{molg}^{-1}\right)\end{array}$ \\
\hline AM\#1 & 70 & 0 & $56 \pm 7,6$ & $1,97 \pm 0,03$ & 45 & 0,01 & $1,84 \pm 0,02$ \\
AM\#2 & 100 & 0 & $191 \pm 20$ & $2,95 \pm 0,16$ & 68 & 0,01 & $2,75 \pm 0,20$ \\
AM\#3 & 100 & 270 & $101 \pm 7,3$ & $2,24 \pm 0,10$ & 63 & 0,02 & $1,88 \pm 0,07$ \\
AM\#4 & 70 & 270 & $133 \pm 14,5$ & $1,85 \pm 0,13$ & 76 & 0,02 & $1,87 \pm 0,12$ \\
\hline
\end{tabular}

A análise dos resultados indicou que as características das membranas foram influenciadas pelos parâmetros de dose de radiação e tempo de armazenamento a baixa temperatura.

As membranas pré-irradiadas em alta dose (100 kGy) apresentaram maior grau de enxertia, alto WU e maior IEC. Esses resultados confirmam os resultados de EPR, que mostram que em altas doses houve maior formação de um número maior de radicais disponíveis para enxertia, que resultaria por consequência em uma maior quantidade de grupos funcionais disponíveis para o transporte iônico.

Apesar do decaimento dos radicais em função do tempo, é possível verificar que as amostras, pré-irradiadas e enxertadas com monômero de estireno após o período de 270 dias a baixas temperaturas, apresentaram um elevado DOG e IEC independente da taxa de dose utilizada. Esse resultado pode indicar que, após um determinado período de tempo, os radicais formados nas reações de combinação e recombinação dos radicais peroxila foram preservados e reagiram com o monômero de estireno conforme nas reações de enxertia detalhadas anteriormente.

A FIG.40 mostra as imagens das amostras dos filmes após a reação de enxertia e as membranas após a reação de alquilação (na forma $\mathrm{OH}^{-}$) das AM\#1, AM\#2, AM\#3 e AM\#4. 

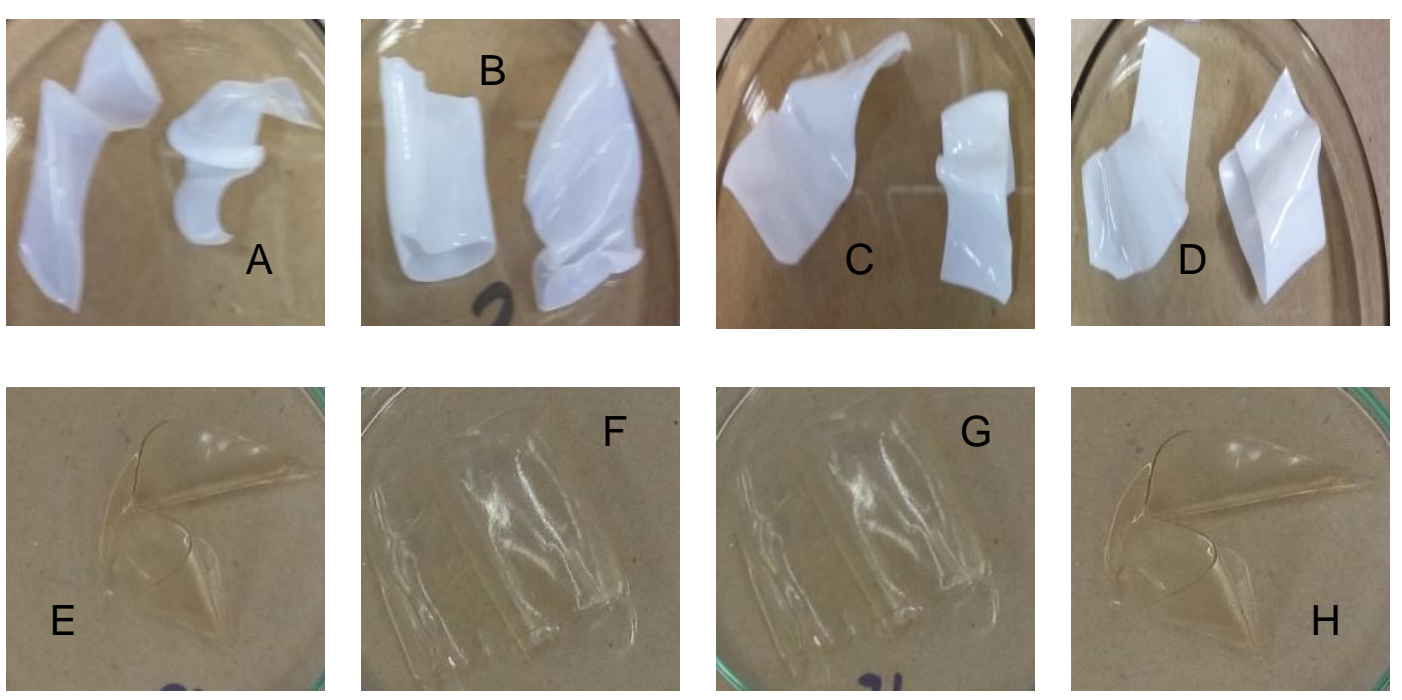

Figura 40 - Imagens das amostras dos filmes e membranas de PETFE pré-irradiados a 70 kGy e enxertados após irradiação e 10 meses a baixa temperatura. Filmes de PETFE pré-irradiados: AM\#1 (A), AM\#2 (B), AM\#3 (C), AM\#4 (D). Membranas hidratadas na forma ( OH-): AM\#1 (E), AM\#2 (F), AM\#3 (G), AM\#4 (H)

É possível observar as diferenças do grau de enxertia (DOG) nos filmes após enxertia,e da capacidade de absorção de água, aumento da espessura e alteração da cor das membranas após a reação de quaternização (maior amarelecimento foi observado em amostras com maior IEC).

\subsection{Microscopia de varredura (MEV)}

As FIG. 41 e 42 mostram as imagens MEV para os filmes PETFE das amostras AM\#1, AM\#2, AM\#3 e AM\#4 após a reação de enxertia com monômero de estireno, e as membranas na forma $\mathrm{OH}^{-}$.

Os filmes de PETFE das AM\#1, AM\#2, AM\#3 e AM\#4 de após a reação de enxertia apresentaram morfologia que dependente do grau de enxertia (DOG). As amostras com maior grau de enxertia apresentaram algumas regiões com maior irregularidade. As irregularidades observadas na superfície dos filmes foram causadas provavelmente por efeitos mecânicos durante o tratamento de limpeza e secagem das amostras. 

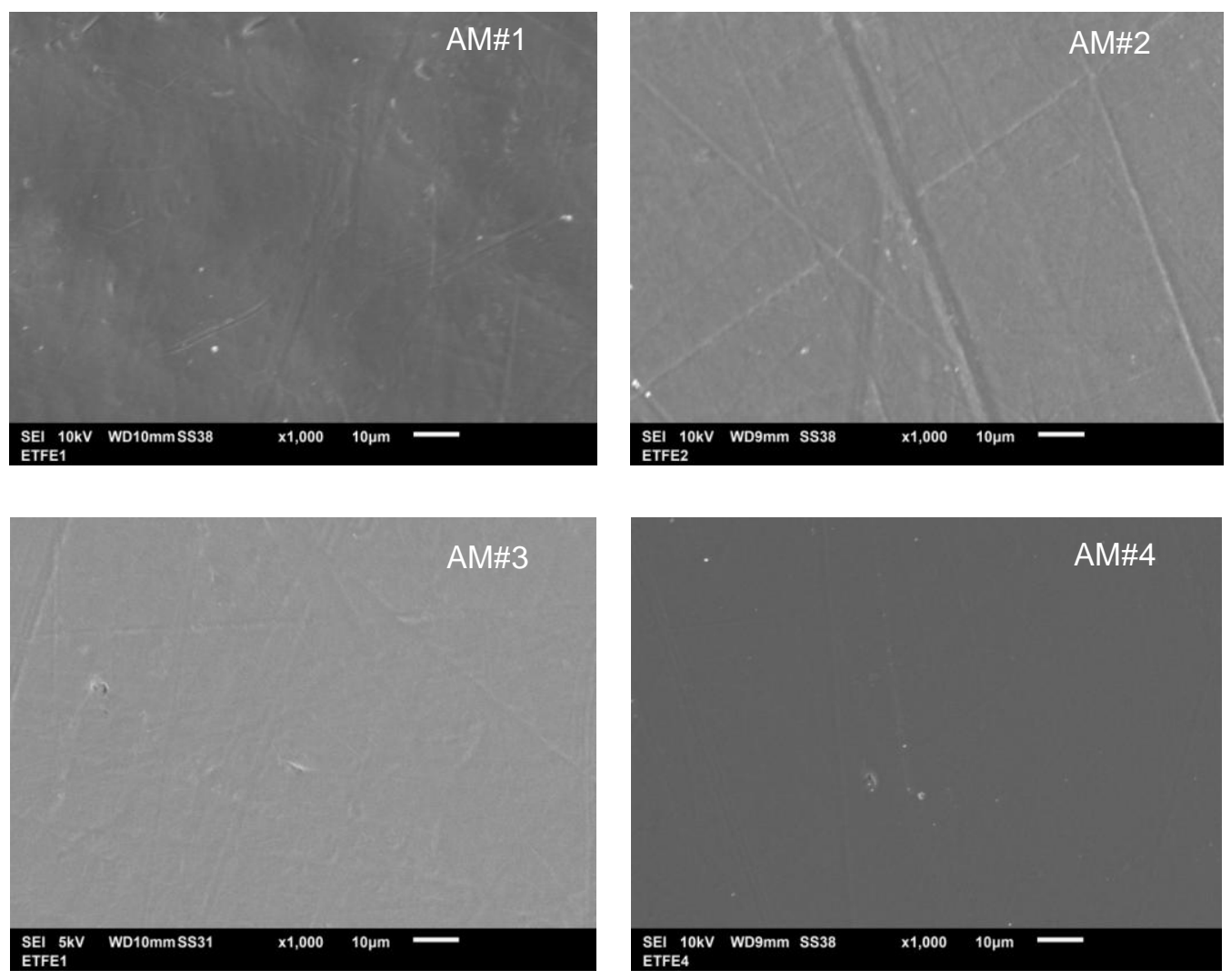

Figura 41 - Imagens MEV dos filmes de PETFE pré-irradiados a 70 kGy ao ar e a temperatura ambiente mantidos a baixa temperatura (-70 $\pm 4 \stackrel{\circ}{ } \mathrm{C})$ em função da dose de radiação e do tempo de armazenamento a baixa temperatura: AM\#1, AM\#2, AM\#3 e AM\#4. Ampliação 3000 x.

As imagens das membranas de PETFE das amostras após a reação de alquilação (na forma $\mathrm{OH}^{-}$) mostraram alterações na morfologia em função da capacidade de absorção de água, evidenciando a manutenção da estrutura os filmes após enxertia. As membranas com maior WU e maior intumescimento apresentaram regiões com maior irregularidade. 

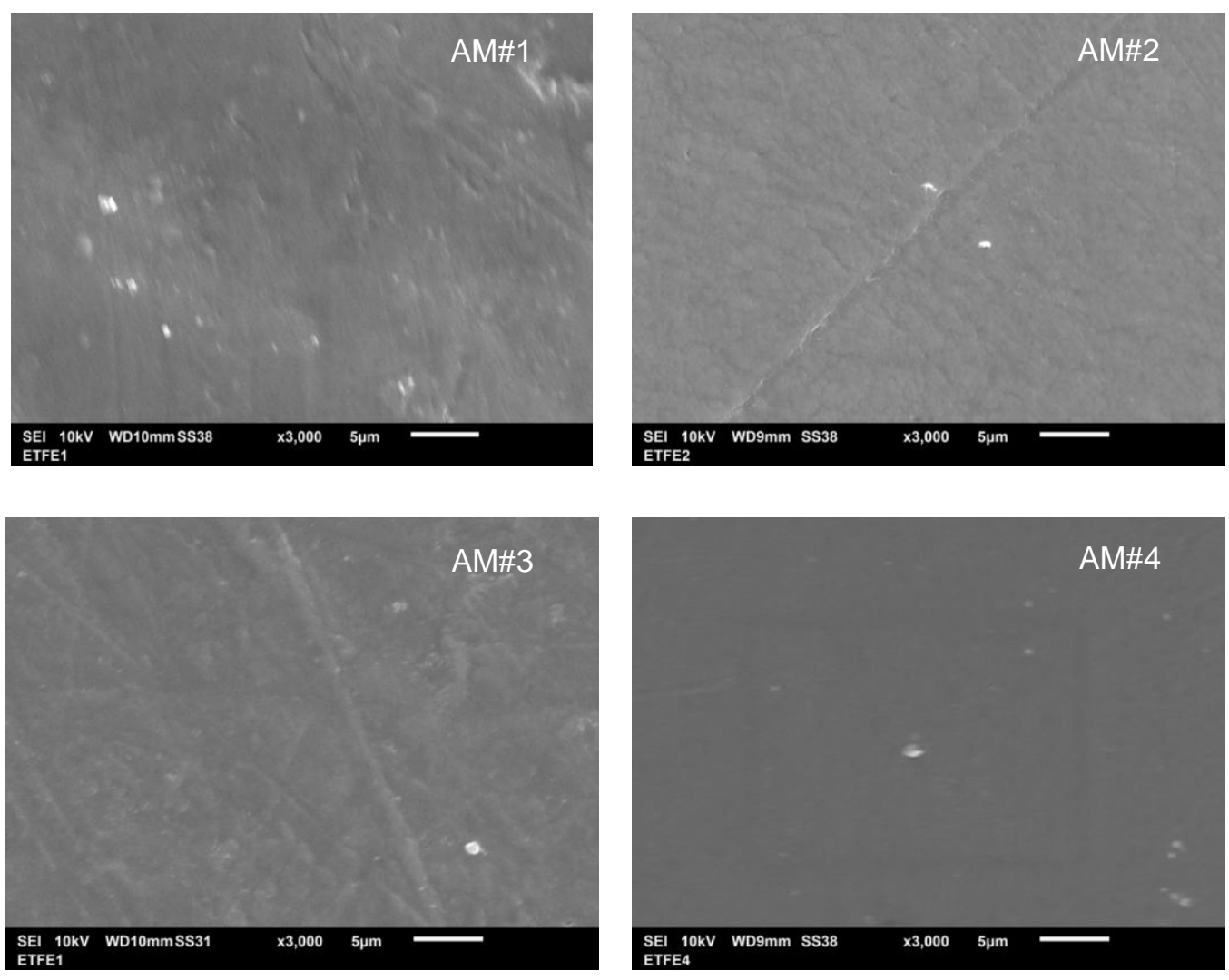

Figura 42 - Imagens MEV das membranas na forma $\left(\mathrm{OH}^{-}\right)$de PETFE pré-irradiados a 70 kGy ao ar e a temperatura ambiente mantidos a baixa temperatura (-70 $\pm 4 \stackrel{\circ}{ } \mathrm{C}) \mathrm{em}$ função da dose de radiação e tempo de armazenamento a baixa temperatura: AM\#1, AM\#2, AM\#3 e AM\#4 (A) Ampliação 3000 x.

\subsection{Termogravimetria}

Na FIG 43 são mostradas as curvas de TG e sua derivada primeira, DTG (mg $\min ^{-1}$ ) obtidas em atmosfera dinâmica de $\mathrm{N}_{2}$ dos filmes de PETFE não irradiado, pré-irradiados a 70 kGy e 100 kGy e enxertados com monômero de estireno imediatamente após a irradiação e após 10 meses de armazenamento em baixa temperatura $(-70 \pm 4 \stackrel{\circ}{\circ})$, e das membranas aniônicas (na forma $\mathrm{OH}^{-}$). 

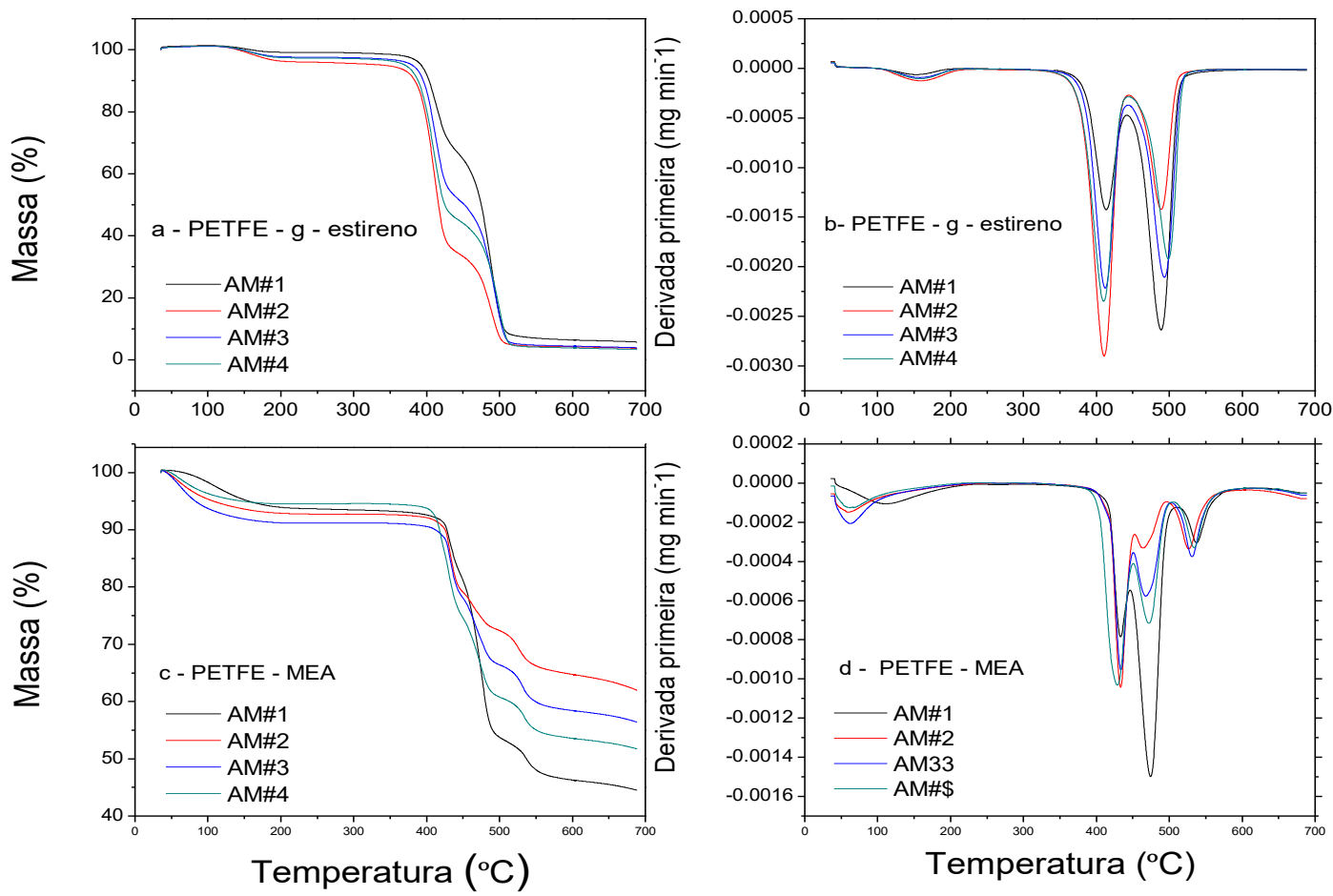

Figura 43 - Curvas TG: (a) e (c); e DTG (b) e (d) das amostras AM\#1, AM\#2, AM\#3, AM\#4: PETFE não irradiadas, PETFE pré-irradiada a 70 kGy e 100 kGy enxertadas com estireno (solução 60:40 estireno: propano-2-ol, v:v) imediatamente após a irradiação e após 10 meses de armazenamento em baixa temperatura (-70 \pm 4 $\left.{ }^{\circ} \mathrm{C}\right)$, e membrana aniônica na forma $(\mathrm{OH}-)$. Medidas em $10^{\circ} \mathrm{C} \mathrm{min}^{-1}$ e sob atmosfera de $\mathrm{N}_{2}$.

No filme de PETFE não irradiados foi observado um único evento de perda de na temperatura de aproximadamente $500{ }^{\circ} \mathrm{C}$ atribuído à degradação da cadeia principal do polímero de PETFE com 98\% de perda de massa (FANG et al., 2012; KO et al. 2012; POYTON e VARCOE, 2015).

Perfis de degradação semelhantes foram observados nos filmes de PETFE das amostras AM\#1, AM\#2, AM\#3 e AM\#4 pré-irradiadas a $70 \mathrm{kGy}$ e 100 kGY enxertadas com monômero de estireno monômero imediatamente após a irradiação e após 10 meses de armazenamento em baixa temperatura $\left(-70 \pm 4^{\circ} \mathrm{C}\right)$ (FIG 43.a). A presença de poliestireno enxertado nos filmes de PETFE não alterou a temperatura de decomposição do polímero base e os 
filmes de PETFE enxertados das amostras AM\#1, AM\#2, AM\#3 e AM\#4 mostraram um evento adicional atribuído à degradação do monômero de estireno enxertado. As perdas de massa das amostras AM\#1, AM\#2, AM\#3 e $\mathrm{AM \# 4}$ iniciaram respectivamente nas temperaturas de $390^{\circ} \mathrm{C}, 380^{\circ} \mathrm{C}, 390{ }^{\circ} \mathrm{C}$ e $380 \stackrel{\circ}{ } \mathrm{C}$ (FIG. 43-a), indicando uma ligeira redução na estabilidade térmica das amostras $A M \# 1, A M \# 3$. Comportamento semelhante foi relatado na literatura (FANG, et al., 2012; KO et al., 2012; POYTON e VARCOE, 2015). Uma etapa de evaporação de compostos voláteis foi observada na faixa de temperatura entre 30 e $270 \stackrel{\circ}{\circ}$ A segunda etapa de degradação da cadeia dos polímeros PETFE enxertados das amostras AM\#1, AM\#2, AM\#3 e AM\#4 ocorreu em $500 \mathrm{C}$ (FIG. 43-a), com perdas de massa de $96 \%$. Perdas de massa semelhantes foram obtidas por (FANG et al., 2012; KO et al., 2012; POYTON e VARCOE, 2015).

Em geral, nas membranas na forma $\left(\mathrm{OH}^{-}\right) \mathrm{AM \# 1,AM \# 2,} \mathrm{AM \# 3} \mathrm{e} \mathrm{AM \# 4}$ ocorreram três eventos de perda de massa iniciados gradativamente até a

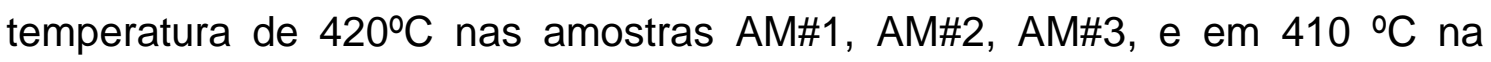
AM\#4 (FIG. 43-b) associada à evaporação de água, solventes orgânicos, monômeros, grupos de amônio, quaternário e grupos sulfônicos indicando um comportamento de retenção de água nas membranas até altas temperaturas. Estas temperaturas podem indicar uma estabilidade térmica das membranas adequada para aplicação em células a combustível alcalinas (AEMFCs). Nesta etapa a decomposição das amostras AM\#1, AM\#2, AM\#3 e AM\#4 ocorreu em $430 \stackrel{\circ}{ } \mathrm{C}$.

A segunda etapa de degradação das amostras AM\#1, AM\#2, AM\#3 e AM\#4 observada na temperatura de $480{ }^{\circ} \mathrm{C}$ (FIG. 43-b) foram associadas à degradação dos grupos aromáticos do monômero enxertado. As perdas de massa variaram entre 10 e $20 \%$, sugerindo uma relação com o grau de enxertia (DOG).

A etapa final de decomposição da cadeia principal do polímero de PETFE das amostras AM\#1, AM\#2, AM\#3 e AM\#4 ocorreram em $540 \stackrel{\circ}{\circ}$ (FIG. 43-b) com perdas de massa de 40 a $55 \%$, respectivamente. Os resíduos podem ser atribuídos a presença de resíduos de enxofre, óxidos e alguma substância 
inorgânica formada durante a reação de enxertia. (SHERAZI et al., 2009; FANG, et al., 2012; KO et al, 2012; POYTON e VARCOE, 2015). Os resíduos não foram analisados. A temperatura de termino do estudo de degradação ocorreu na temperatura $700 \stackrel{\circ}{\mathrm{C}}$.

\subsection{Espectroscopia de impedância}

A variação da condutividade das membranas em função da temperatura para as membranas PETFE pré-irradiadas em 70 kGy e 100 kGy, enxertadas com monômero de estireno imediatamente após a irradiação e 270 dias após a irradiação, e funcionalizadas com TMA é mostrada na FIG. 44.

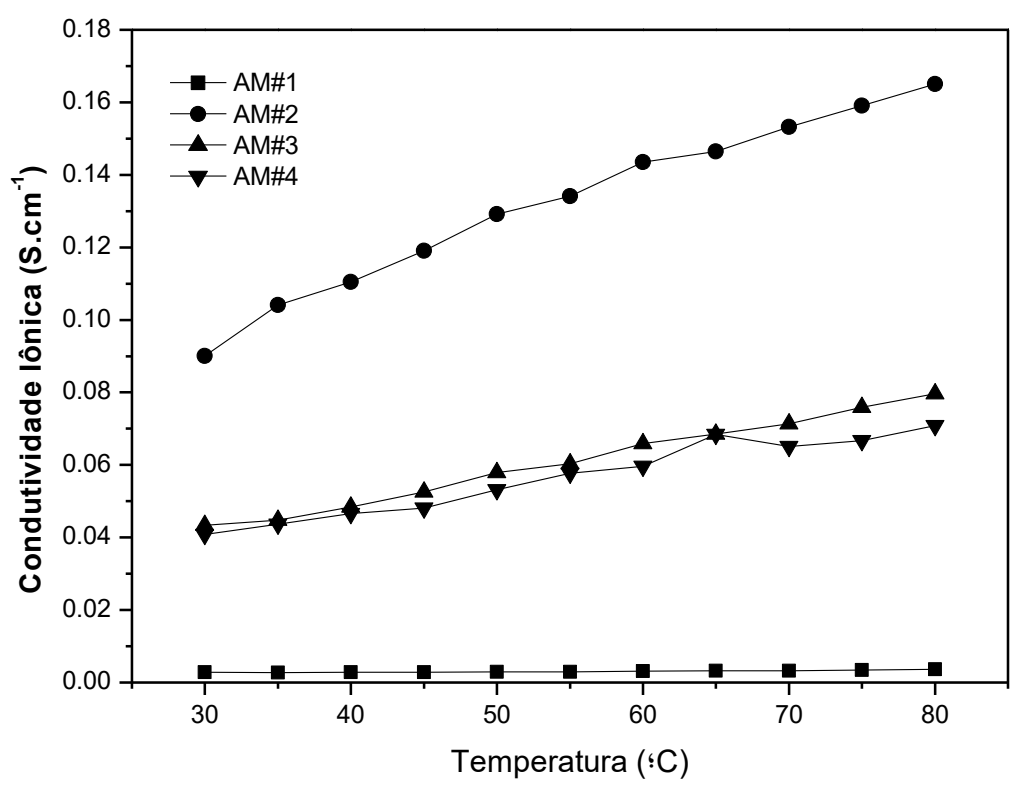

FIGURA 44 - Condutividade aniônica das membranas aniônicas hidratadas na forma $(\mathrm{OH})$ do polímero de PETFE: AM\#1, AM\#2, AM\#3, AM\#4. Medidas em RH = $100 \%, 2$ pontas, faixa de frequência de $30 \mathrm{MHz}$ a $0,1 \mathrm{~Hz}$.

O valor de condutividade de $112,8 \mathrm{mS} \mathrm{cm}^{-1}$ a $50{ }^{\circ} \mathrm{C}$, encontrado para a membrana \# 1, é expressivo e próximo ao Nafion $^{\mathrm{TM}} 115(\sigma=0,104 \pm 0,008 \mu \mathrm{m}$, a $50 \stackrel{\circ}{\circ}$ ) VARCOE et al. (2007). Valores de condutividade expressivos também foram encontrados com as membranas 3 e $4\left(0,059\right.$ e 0,053 S.cm $^{-1}$, a $\left.50{ }^{\circ} \mathrm{C}\right)$. 
Estes resultados estão em boa concordância com os dados de DOG e IEC, que mostram que os filmes de PETFE pré-irradiados em doses 100 kGy e enxertados imediatamente após a irradiação tem maior numero de grupos funcionais disponíveis para a condução iônica. Os valores de condutividade encontrados demonstram que as membranas sintetizadas sob essas condições apresentaram propriedades promissoras para a aplicação como eletrodos em células alcalinas.

No gráfico de Arrhenius (FIG. 45) das membranas estudas observou-se que a resistência das amostras diminuiu gradativamente com o aumento da temperatura.

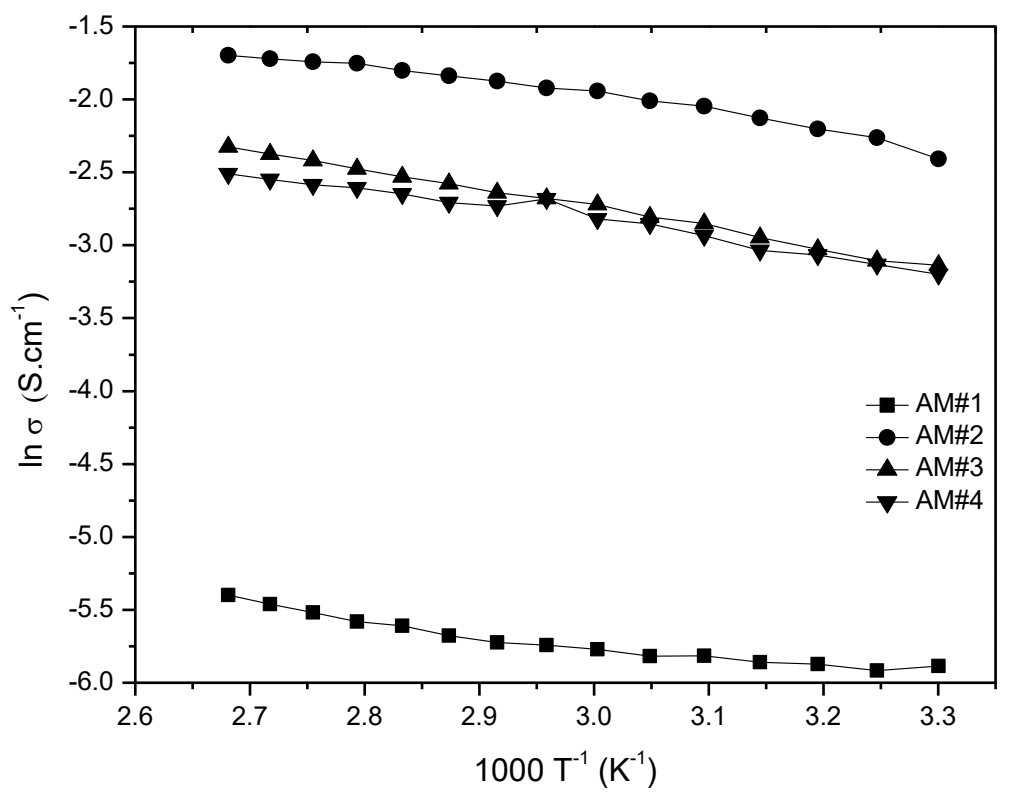

FIGURA 45 - Gráfico de Arrhenius das membranas aniônicas do polímero de PETFE AM\#1, AM\#2, AM\#3 e AM\#4 hidratadas na forma $\left(\mathrm{OH}^{-}\right)$.

As energias de ativação estimadas utilizando a equação Eq. 30 assim como os valores de condutividade iônica, estão sumarizadas na TAB. 11 . 
TABELA 11 - Resultados de condutividade e energia de ativação das membranas AM\#1, AM\#2, AM\#3 e AM\#4.

\begin{tabular}{ccccc}
\hline Amostra & $\begin{array}{c}\text { Dose } \\
\text { kGy }\end{array}$ & $\begin{array}{c}\text { Tempo } \\
\text { (dias) }\end{array}$ & $\begin{array}{c}\sigma_{\max .} \\
\left({\left.\mathrm{S} . \mathrm{cm}^{-1}\right), 80}^{\circ} \mathrm{O}\right.\end{array}$ & $\begin{array}{c}\mathrm{E}_{\mathrm{a}} \\
\mathrm{kJ} \cdot \mathrm{mol}^{-1}\end{array}$ \\
\hline AM\#1 & 70 & 0 & 0,0045 & 6,61 \\
AM\#2 & 100 & 0 & 0,1692 & 8,95 \\
AM\#3 & 100 & 270 & 0,0660 & 11,13 \\
AM\#4 & 70 & 270 & 0,0585 & 9,27 \\
\hline
\end{tabular}

Os resultados de energia de ativação foram próximos ao reportado por VARCOE et al. (2007), relataram condutividade iônica cerca de $34 \mathrm{~m} \mathrm{~S} \mathrm{~cm}^{-1} \mathrm{a}$ $50{ }^{\circ} \mathrm{C}$ e $\mathrm{E}_{\mathrm{a}}$, cerca de $6,20 \mathrm{~kJ} \mathrm{~mol}^{-1}$, valor próximo ao do Nafion ${ }^{\mathrm{TM}} 115$ cerca de $7,1 \mathrm{~kJ} \mathrm{~mol}^{-1}$ ao sintetizar membranas PETFE $(50 \mu \mathrm{m})$ enxertadas com VBC e funcionalizadas com TMA. Neste estudo, a membrana AM\#1, com menor energia de ativação,Ea, exibiu a menor condutividade, provavelmente devido ao baixo grau de enxertia, porém próximo ao reportado por VARCOE et al. (2007).

A análise dos resultados obtidos mostrou que doses absorvidas de radiação mais altas e tempos mais curtos de armazenamento parecem aumentar a condutividade das membranas. Em tempos mais longos de armazenamento e doses mais altas tendem a aumentar a capacidade de absorção de água (WU) das membranas. As alterações na dose de radiação e tempo de armazenamento parecem não influenciar na capacidade de troca iônica (IEC).

\subsection{Poli (tetrafluoroetileno-co-hexafluoropropileno) (PFEP)}

\subsubsection{Processo simultâneo de irradiação}

Os filmes de PFEP foram irradiados no Irradiador Multipropósito de ${ }^{60} \mathrm{Co}$ com doses absorvidas de radiação de 20, 40, 60 kGy (taxa de dose médias 
11,4 kGy. $\mathrm{h}^{-1}$ ) nas seguintes soluções de monômero de estireno: estireno:tolueno 60:40 (v:v), estireno:propan-2-ol 60:40 (v:v), e estireno:tolueno 20:80 (v:v). Na TAB.12 são apresentados os parâmetros de processo e os resultados do grau de enxertia (DOG).

Tabela 12 Parâmetros de processo e resultados do grau de enxertia (DOG) do polímero de PFEP nas soluções de estireno:tolueno 60:40 (v:v), estireno:propano-2-ol 60:40 (v:v) e estireno:tolueno 20:80 (v:v) em função da dose absorvida de radiação.

\begin{tabular}{cccc}
\hline \multirow{2}{*}{$\begin{array}{c}\text { Dose radiação } \\
(\mathrm{kGy})\end{array}$} & \multicolumn{3}{c}{$\begin{array}{c}\text { Grau de enxertia (DOG) } \\
(\%)\end{array}$} \\
\cline { 2 - 4 } & $\begin{array}{c}\text { Estireno:tolueno } \\
60: 40(\mathrm{v}: \mathrm{v})\end{array}$ & $\begin{array}{c}\text { Estireno:propano-2-ol } \\
60: 40(\mathrm{v}: \mathrm{v})\end{array}$ & $\begin{array}{c}\text { Estireno:tolueno } \\
20: 80(\mathrm{v}: \mathrm{v})\end{array}$ \\
\hline 20 & 0,65 & 0,26 & 1,51 \\
40 & 4,4 & 3,96 & 1,89 \\
60 & 5,25 & 3,79 & 4,15 \\
\hline
\end{tabular}

Os filmes de PFEP enxertados utilizando o método de irradiação simultânea processado no irradiador Multipróposito de ${ }^{60} \mathrm{Co}$, apresentaram enxertia heterogênea, e com graus de enxertia (DOG) entre 0,65 e 5,2 \%. Os baixos valores de DOG e heterogeneidade da enxertia das amostras inviabilizam a síntese de membranas aniônicas para a aplicação em células alcalinas, e podem ser relacionados à menor susceptibilidade dos filmes de PFEP a formação de radicais devido a estabilidade das ligações C-F presentes na cadeia do polímero. Estes resultados são inferiores aos encontrados por WALSBY et al. (2001); HERMAN et al. (2003) e SLADE, VARCOE (2005).

WALSBY et al. (2001) estudaram o comportamento/desempenho de uma série membranas de diferentes polímeros fluorados, entre eles o PFEP, préirradiados por feixe de elétrons a 50 kGy, e enxertados com monômero de estireno a $70^{\circ} \mathrm{C}$, obtendo membranas com grau de enxertia de $30 \%$ A variação nos graus de enxertia observados nos diversos polímeros estudados foi influenciada pela combinação de fatores como, concentração de radicais 
formados na irradiação, diferentes estruturas dos radicais, variação na cristalinidade, e temperatura de transição vítrea $\left(T_{g}\right)$ dos polímeros.

HERMAN et al. (2003) estudaram a influência dos parâmetros de enxertia na obtenção de membranas com filmes de PFEP pré-irradiados nas doses entre 63 a 100 kGy em diversas condições de enxertia. Os graus de enxertia das membranas enxertadas com VBC variaram entre 3,3 a $28,9 \%$, e mostraram-se dependentes da dose de radiação, tempo e temperatura de enxertia, e concentração do VBC.

SLADE e VARCOE (2005) preparam uma série de membranas enxertadas com VBC via pré-irradiação nas doses entre 40 e $70 \mathrm{kGy}$, com graus de enxertia entre 20 a $26 \%$, e condutividade iônica de até $23 \mathrm{mS} . \mathrm{cm}^{-1}$ a $50 \stackrel{\circ}{ }$, e observaram que graus de enxertia inferiores a $21 \%$, reduziram a condutividade das membranas na forma $\mathrm{OH}^{-}$, e além disso, seria necessário a irradiação em doses maiores para obter graus de enxertia superiores a 26\%, o que poderia causar a fragilização da membrana.

Embora os resultados sejam insuficientes para a síntese de membranas aniônicas, é possível observar a influência, da dose total, do solvente, e da concentração de monômero. Houve um aumento no (DOG) com o aumento da dose de radiação. Esta mesma tendência foi observada por HERMAN et al. (2003); e por SLADE e VARCOE (2005). O incremento maior da dose de radiação poderia aumentar ainda mais $\mathrm{(DOG})$, entretanto, doses de radiação acima de $100 \mathrm{kGy}$ podem causar a fragilização do polímero de PFEP, e inviabilizar a aplicação da membrana em células alcalinas (HERMAN et al., 2003, SLADE e VARCOE, 2005).

A variação na concentração de monômero e tipo de solvente influenciou de forma diferente os DOG nas diferentes doses. As amostras irradiadas com a dose de $20 \mathrm{kGy}$, soluções com concentrações menores de estireno em propano-2-ol apresentaram maiores graus de enxertia, enquanto com as doses absorvidas de radiação de 40 e 60 kGy os maiores graus de enxertia foram obtidos nas soluções contendo maior concentração de monômero nos solventes tolueno e propano-2-ol. Essas variações podem estar relacionadas com a solubilidade do solvente, e espessura do filme de PFEP (WALSBY et al.; 
2001; SLADE e VARCOE, 2005). São necessários estudos mais aprofundados para entender e definir melhor esses parâmetros de processo

\subsubsection{Microscopia de força atômica usando modo de força máxima QNM}

A influência dos parâmetros de enxertia por irradiação simultânea (dose de radiação, tempo de enxertia, concentração de monômero e tipo de solvente) na morfologia e nas propriedades mecânicas dos filmes de PFEP irradiados nas doses de 40 e $60 \mathrm{kGy}$ foram analisadas por microscopia de força atômica usando força máxima QNM.

Para avaliar o efeito do tempo de enxertia, uma amostra (amostra $D$ ) foi irradiada na solução de estireno:tolueno 60:40 (v:v) em atmosfera inerte $\left(\mathrm{N}_{2}\right)$, a $60 \mathrm{kGy}$, e em seguida mantida por 24 horas a $60 \stackrel{\circ}{ } \mathrm{C}$, obtendo-se um grau de enxertia de $18 \%$. Ainda assim, os valores de DOG alcançados para esse tipo de polímero base são considerados baixos para a obtenção de membranas com condutividade satisfatórias para a aplicação em AFC.

Os parâmetros de processo utilizados na enxertia e os resultados do grau de enxertia dos filmes de PFEP estão apresentados na TAB. 13.

TABELA 13 - Resultados do grau de enxertia dos filmes de PFEP e parâmetros de processo (taxa de dose: $11,4 \mathrm{kGy} \cdot \mathrm{h}^{-1}$ ).

\begin{tabular}{ccccc}
\hline Amostra & $\begin{array}{c}\text { Dose de radiação } \\
(\mathrm{kGy})\end{array}$ & Solução Monômero & $\begin{array}{c}\text { Concentração } \\
\text { Monômero:Solvente (v:v) }\end{array}$ & $\begin{array}{c}\text { DOG } \\
(\%)\end{array}$ \\
\hline A & \multicolumn{5}{c}{ Filme FEP (não irradiado) } \\
B & 60 & estireno:tolueno & $60: 40$ & 5,3 \\
C & 40 & estireno:tolueno & $60: 40$ & 4,4 \\
$\mathrm{D}^{(*)}$ & 60 & estireno:tolueno & $60: 40$ & 18,4 \\
E & 60 & estireno:tolueno & $20: 80$ & 4,2 \\
F & 60 & estireno:propano-2-ol & $60: 40$ & 3,8 \\
G & 40 & estireno:propano-2-ol & $60: 40$ & 4,0 \\
\hline
\end{tabular}

${ }^{*}$ ) Enxertia adicional após irradiação: 24 horas a $60 \stackrel{\circ}{ } \mathrm{C}$ 
As imagens do AFM usando o modo de operação força máxima QNM mostradas nas FIG. 46 e 47 indicaram que a morfologia e as propriedades mecânicas (adesão e módulo elástico) dos filmes de PFEP enxertados podem ser influenciadas pelas condições de enxertia, grau de enxertia (DOG) e tipo de solvente. A rugosidade $(\mathrm{Ra})$ foi calculada com base na média dos valores dos picos e vales do plano.

Na FIG. 46, é mostrada a morfologia obtida por AFM dos filmes de PFEP irradiados nas soluções de estireno:tolueno e estireno propano-2-ol (60:40, $\mathrm{v}: \mathrm{v})$, nas doses 40 e $60 \mathrm{kGy}$ (B,C,G e F), sofreram alterações na rugosidade com as variações da dose de radiação e tipo de solvente. Observou-se que os filmes irradiados com dose absorvida de radiação de $40 \mathrm{KGy}$ apresentaram maior rugosidade $(\mathrm{Ra})$.

As imagens sugeriram que a enxertia do poliestireno ocorreu de forma diferente nas diversas soluções, quando o solvente tolueno foi utilizado a enxertia ocorreu na superfície do filme de PFEP, formando uma deposição de poliestireno com rugosidade média variando entre 13,3 a 83,1 nm (FIG. 46 BE). Enquanto que, a enxertia nas soluções de propano-2-ol (FIG. 46 F-G) a formação ocorreu através da matriz do polímero de PFEP, com rugosidade variando entre $150-158 \mathrm{~nm}$. 


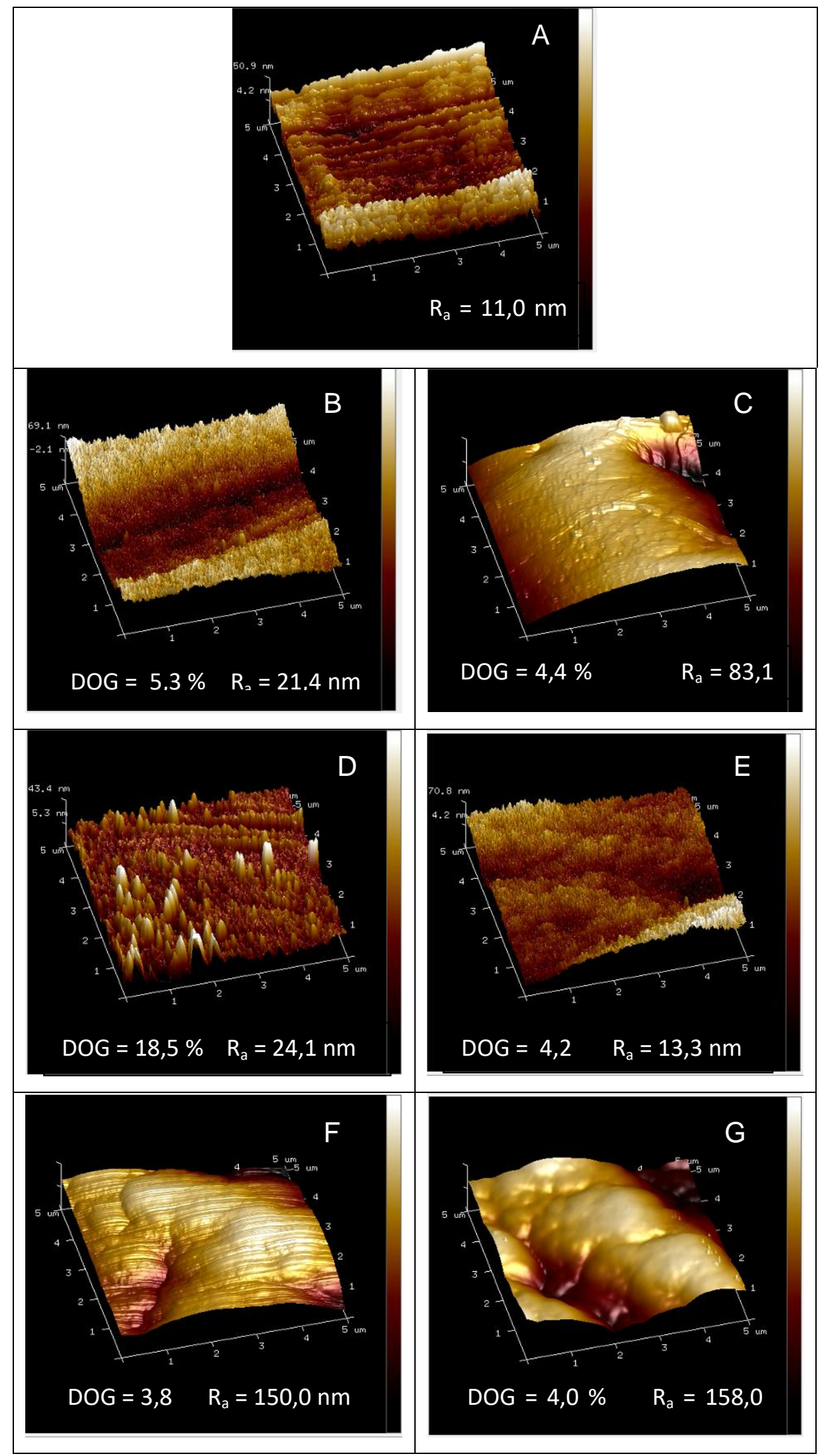

FIGURA 46 - Micrografias de força atômica, usando modo PeakForce QNM dos filmes de PFEP enxertados nas condições: (A) sem irradiar, (B) 60 kGy,6 h, S:T 60:40 (v:v), (C) 40 kGy, 4 h, S:T 60:40 (v:v), (D) 60 kGy, 30 h, S:T 60:40 (v:v),, (E) 60 kGy,6 h, S:T 20:80 (v:v), (F) 60 kGy,6 h, S:P 60:40 (v:v) 
Estes resultados podem ser explicados pelas distintas solubilidades do polímero nos diversos solventes, como o tolueno não é um bom solvente para o PFEP, o estireno não tem acesso aos radicais formados nas camadas internas da matriz polimérica, e a enxertia ocorre na camada superficial do polímero. O monômero de estireno é pouco solúvel no solvente propano-2-ol e consegue manter os radicais formados pela irradiação por mais tempo, e desta forma consegue atingir camadas mais internas do polímero. E poderiam justificar o baixo grau de enxertia obtido quando foi utilizado o solvente xileno.

As imagens obtidas utilizando AFM em modo de operação QNM sugeriram que a enxertia do estireno no solvente tolueno (FIG 46 - amostra F) ocorreu de forma homogênea na superfície da membrana quando comparada com a solução em tolueno. Em soluções de estireno, os alcoóis têm a função de não-solventes, ao contrário do tolueno que age como um solvente verdadeiro (alta solubilidade). A incompatibilidade do álcool com a fase polimérica pode causar redução da mobilidade das cadeias poliméricas em crescimento na solução, aumentando a concentração de monômero e o tempo de vida dos radicais e, consequentemente, melhorando a taxa de polimerização e as propriedades mecânicas do filme enxertado (RAGER, 2003).

Embora o número de experimentos realizados não seja suficiente para confirmar estas conclusões, estes resultados estão de acordo com os resultados acordo com os resultados obtidos por WALBSY (2000), ao observar que o grau de enxertia e as propriedades mecânicas dos filmes irradiados dependem do solvente utilizado.

O modo de força máxima QNM forneceu informações de aderência (entre a ponta e a superfície da amostra) e o módulo elástico separadamente (FIG. 47). Os contrastes observados nas imagens $C, D$ e $F$ indicaram as propriedades mecânicas dos filmes enxertados podem ser influenciadas pelo tempo de enxertia, dose de radiação, e tipo de solvente. Não foram observados contrastes nas amostras A, B e E. 
ADHESION
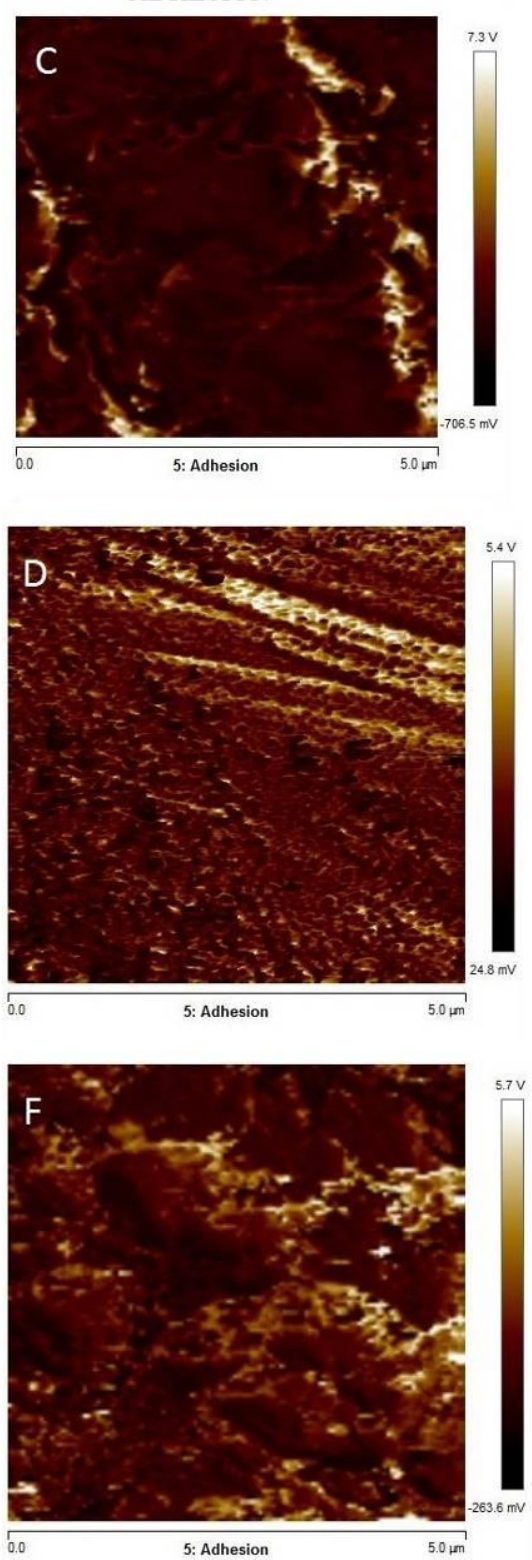

ELASTIC MODULUS
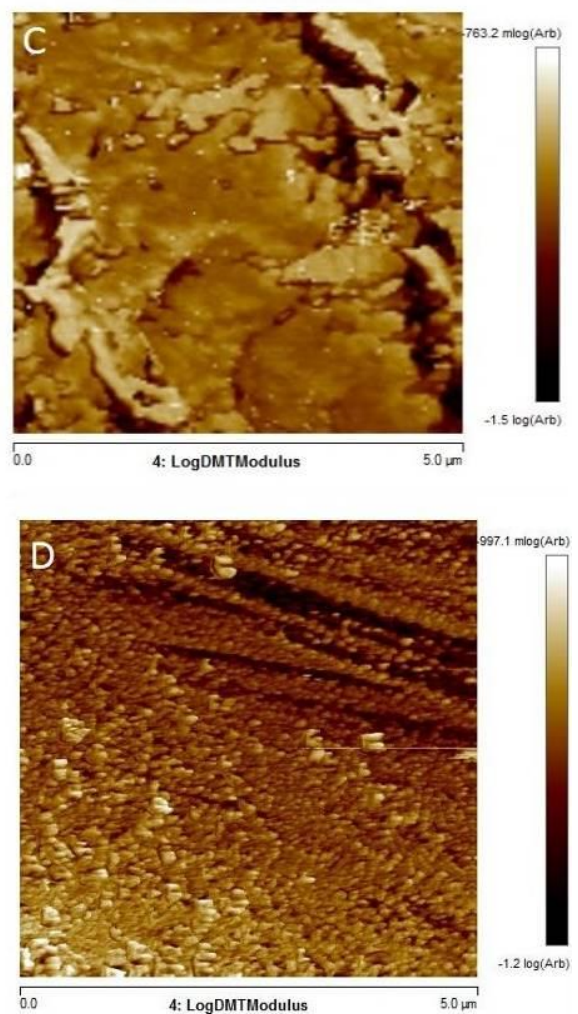

4: LogDMTModulus

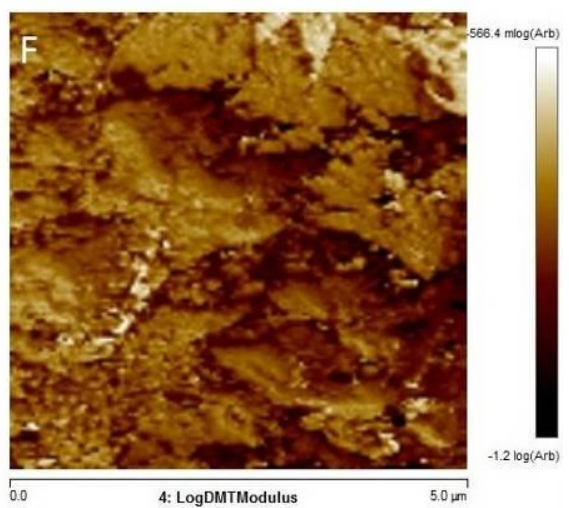

FIGURA 47 - Micrografias de força atômica mostrando a aderência (entre ponta e superfície) e modulo elástico obtido por PeakForce QNM dos filmes de PFEP nas condições (C) 40 kGy, 4 h, S:T 60:40 v:v, (D) 60kGy, 30 h, S:T 60:40 v:v, (F) 60 kGy, 6 h, S:P 60:40 v:v.

\subsubsection{Processo de pré-irradiação dos filmes de PFEP}

\subsubsection{Estabilidade dos radicais}

Para verificar a formação de radicais livres dos filmes de PFEP préirradiados a 70 kGy ao ar, e a estabilidade desses radicais armazenados a 
baixa temperatura $(-70 \pm 4 \stackrel{\circ}{\circ})$, foram realizadas análises por espectroscopia de ressonância paramagnética (EPR) durante 8 meses.

Na FIG. 48 são apresentados os espectros da variação de intensidade com tempo de armazenamento a baixa temperatura $(-70 \pm 4 \stackrel{\circ}{\circ})$, no período de 240 dias

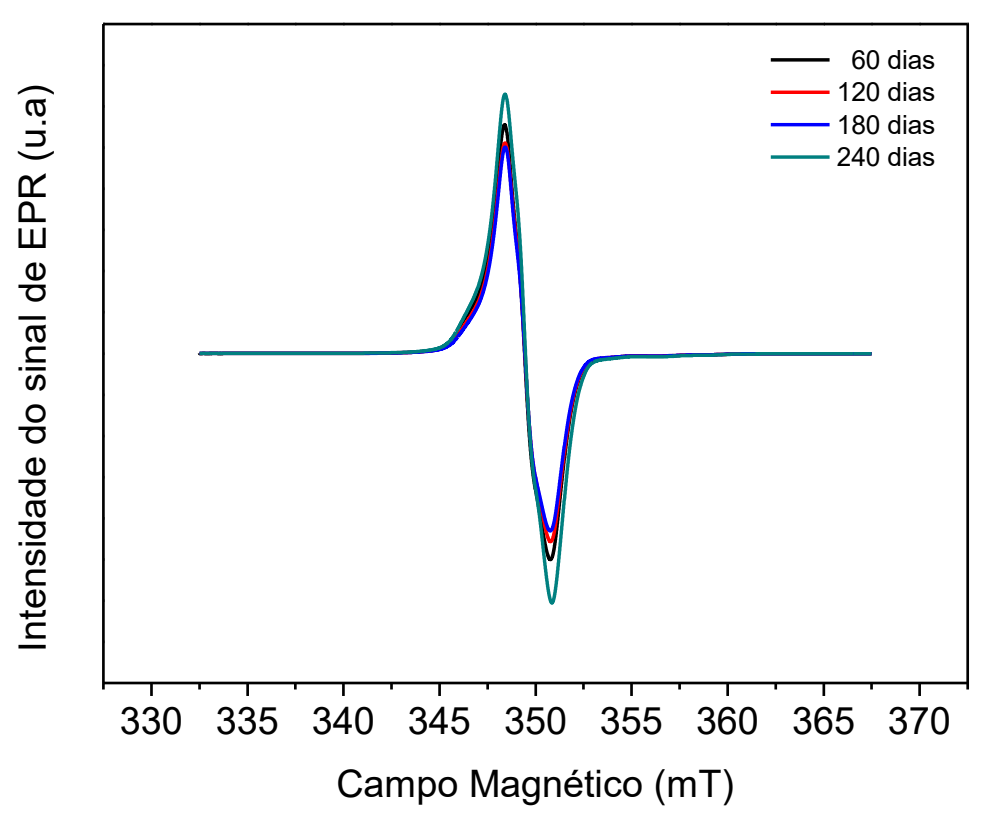

FIGURA 48 - Espectros EPR dos filmes de PFEP pré-irradiados a 70 kGy e armazenados a baixa temperatura $(70 \pm 4 \stackrel{\circ}{\circ})$ durante 240 dias, irradiados e medidos a temperatura ambiente.

Observa-se nos filmes de PFEP pré-irradiados a 70 kGy e mantidos durante 6 meses a baixa temperatura $(70 \pm 4 \stackrel{\circ}{\circ})$, a presença predominante de radicais peróxidos $(\mathrm{ROO})$ na faixa de campo magnético entre $345-355 \mathrm{mT}$. O valor de $g=2.0193$ foi calculado conforme Eq. 27. Estes valores estão de acordo com os resultados encontrados por MITOV et al. (2006). Não houve variação na forma do espectro, campo magnético, e valor de $g$ durante 0 período de 8 meses, sugerindo que os radicais peróxidos foram preservados na matriz polimérica quando armazenados a baixa temperatura. 
$\mathrm{Na}$ FIG 49 foram mostrados o decaimento dos radicais dos filmes de PFPE em função do tempo de armazenamento a baixas temperatura durante 180 dias.

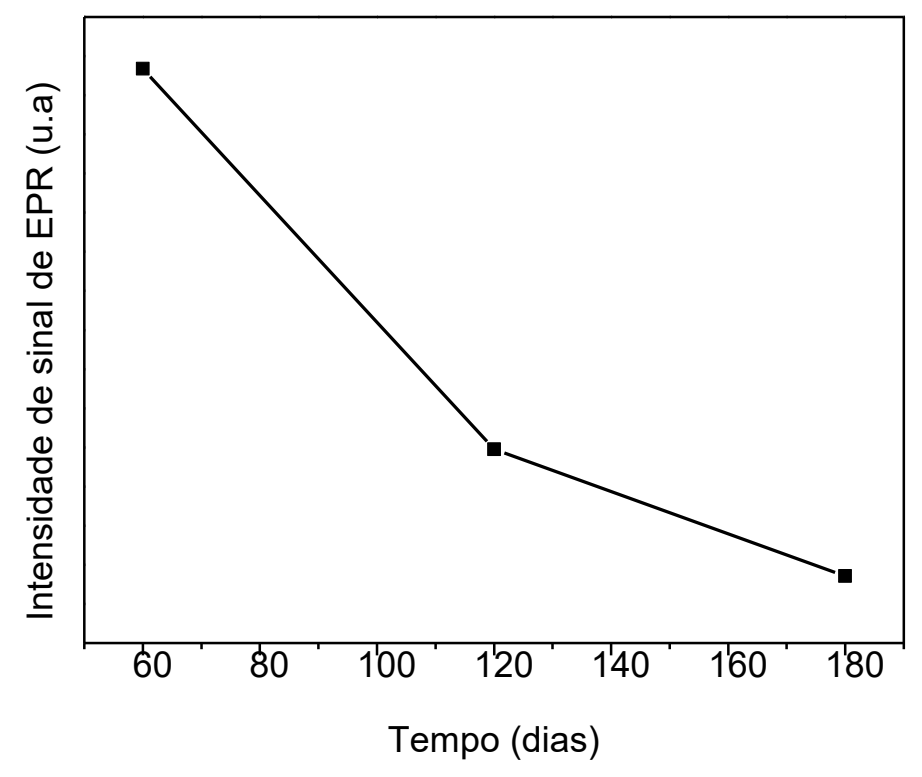

FIGURA 49 - Amplitude do sinal EPR pico-a-pico normalizado versus tempo de armazenamento a baixa temperatura $\left(-70 \pm 4^{\circ} \mathrm{C}\right)$ dos filmes de PFEP, pré-irradiados a 70 kGy e armazenados a baixa temperatura $\left(-70 \pm 4{ }^{\circ} \mathrm{C}\right)$ durante 240 dias, irradiados e medidos a temperatura ambiente.

O decaimento dos radicais sugere uma tendência polinomial de segunda ordem, segundo a equação 36 .

$Y=-59399 x^{2}+13855764 x+2,89575 E 7$

Após 60 dias observou-se uma redução de $25 \%$ dos radicais após, que pode ser resultante da reação de recombinação (EQ.35).

\subsubsection{Grau de enxertia (DOG)}

No processo de pré-irradiação foram obtidos graus de enxertia de $50 \%$ para as amostras pré-irradiadas a 70 kGy em feixe de elétrons e enxertadas na 
solução estireno:propano-2-ol durante 24 horas a $60^{\circ} \mathrm{C}$. Foram observadas, porém, formação de bolhas durante a limpeza dos filmes com xilol e craqueamento dos filmes após a secagem a $60{ }^{\circ} \mathrm{C}$, impossibilitando a realização das medidas de IEC e WU.

\subsubsection{Espectroscopia Raman}

Os espectros Raman dos filmes de PFEP: (a) não irradiados, (b) filmes de PFEP pré-irradiados com feixe de elétrons a $70 \mathrm{kGy}$ ao ar à temperatura ambiente, e enxertado na solução estireno:propano-2-ol (60:40, v:v) por 24 horas a $60 \stackrel{\circ}{\circ}$ (c) filmes de PFEP irradiado pelo processo simultâneo em solução estireno:propano-2-ol (60:40, v:v), e mantido por 24 horas a $60 \stackrel{\circ}{\circ}$, são mostrados na FIG. 50.

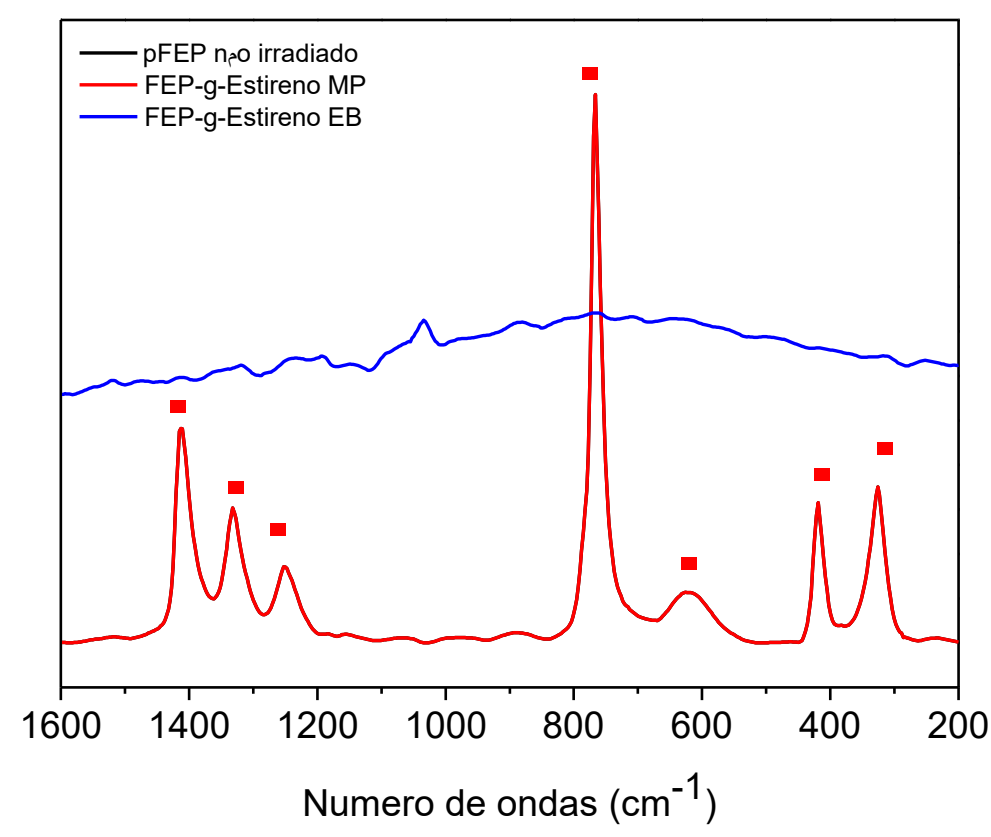

FIGURA 50 - Espectros Raman dos filmes de PFEP não irradiados, irradiados no irradiador Multipropósito de ${ }^{60} \mathrm{Co}$ (espectros sobrepostos) e no acelerador de elétron enxertados em solução de estireno:propano-2-ol (60:40, V:V).

Os espectros dos filmes de PFEP não irradiado, e dos filmes enxertados pelo processo de irradiação simultânea ficaram sobrepostos, apresentando apenas os principais estiramentos do PFEP, ligações C-C $\left(1411 \mathrm{~cm}^{-1}\right.$, 
$\left.1381 \mathrm{~cm}^{-1}, 1246 \mathrm{~cm}^{-1}, \mathbf{m}\right)$, e $\mathrm{CF}_{2}\left(764 \mathrm{~cm}^{-1}, 620 \mathrm{~cm}^{-1}, 421 \mathrm{~cm}^{-1}, 326 \mathrm{~cm}^{-1}, \mathbf{m}\right)$. Embora com grau de enxertia $18 \%$, não tenham sido identificados os estiramentos do monômero de estireno nos filmes de PFEP enxertados. Os filmes de PFEP pré-irradiados e enxertados, com DOG 50\%, não apresentaram estiramentos do PFEP e do monômero de estireno este resultado pode indicar uma cisão na cadeia do polímero, possivelmente devido as características de $\mathrm{T}_{\mathrm{g}}$ e cristalinidade do polimero PFEP, que pode ter ocorrido devido ao craqueamento do filme enxertado após a limpeza com xileno e secagem a $60 \mathrm{C}$.

O polímero de PFEP demonstrou considerável resistência à radiação nas condições empregadas nos processos de irradiação simultâneo e préirradiação. Os resultados pobres de grau de enxertia e a predominância da reação de cisão de cadeia impossibilitaram a síntese de membranas aniônicas com filmes de PFEP. Nos estudos realizados anteriormente por HERMAN et al (2003), SLADE e VARCOE (2005), os autores desenvolveram membranas aniônicas funcionalizadas com trimetilamina química e termicamente estáveis para aplicação em células a combustível alcalinas, pelo processo de irradiação de polímeros PFEP, obtendo resultados de condutividade iônica na forma hidratada entre 1,0 e $3,5 \mathrm{mS} \mathrm{cm}^{-1}$, na faixa de temperatura 20 a $80{ }^{\circ} \mathrm{C}$. Entretanto, não foram realizados testes em célula alcalina, devido à falta de estabilidade e propriedades mecânicas ruins das membranas sintetizadas neste trabalho, atribuídas a resistência à radiação do PFEP, que exigem doses de radiação que podem degradar as cadeias dos filmes de PFEP.

LAPPAN et al. (2009) observaram que o grau de enxertia e as propriedades mecânicas de filmes de PFEP foram influenciados pela temperatura de irradiação, e a cisão das cadeias pode ser a causa da deterioração das propriedades mecânicas após tratamento abaixo da temperatura de transição vítrea $\left(T_{g}\right)$.

Neste caso será necessário um estudo dos parâmetros de irradiação e das condições de armazenamento para a síntese de membranas aniônicas. 


\section{CONCLUSÃO}

As membranas aniônicas foram sintetizadas com filmes de polietileno de baixa densidade (LDPE), polietileno de ultra alto peso molecular (UHMWPE), poli(etileno-co-tetrafluoroetileno (PETFE) e poli(tetrafluoroetileno-cohexafluoroetileno) (PFEP) por enxertia com monômero de estireno via irradiação nos processos simultâneo e de pré-irradiação com radiação gama provenientes de fontes de ${ }^{60} \mathrm{Co}$ e com feixe de elétrons provenientes de acelerador de elétrons.

Foram identificados parâmetros de processos adequados para obtenção de filmes com elevada homogeneidade e condutividade iônica satisfatória para aplicação em células alcalinas.

Foi desenvolvido, método de identificação e monitoramento da estabilidade dos radicais formados no processo de pré-irradiação, utilizando-se a técnica de espectroscopia de ressonância paramagnética eletrônica (EPR) que, aliada à técnica de espectroscopia Raman e microscopia de força atômica (AFM) usando modo de força máxima QNM, forneceu informações para a obtenção de filmes com grau de enxertia e homogeneidade satisfatórias.

A caracterização dos filmes e membranas permitiu o entendimento dos diferentes comportamentos dos polímeros estudados e a definição dos métodos e parâmetros para obtenção de membranas aniônicas com possível aplicação em células a combustível alcalinas.

Os parâmetros e características que influenciaram o comportamento e desempenho das membranas de polietileno de baixa densidade (LDPE), polietileno de ultra alto peso molecular (UHMWPE), poli(etileno-cotetrafluoroetileno (PETFE) e poli(tetrafluoroetileno-co-hexafluoroetileno) (PFEP) podem ser resumidos da seguinte forma:

Polímeros não-fluorados - filmes de polietileno de baixa densidade (LDPE), polietileno de ultra alto peso molecular (UHMWPE), LDPE. Os resultados de condutividade iônica (forma $\mathrm{OH}^{-}$) das membranas de LDPE e de UHMWPE, 29 mS.cm ${ }^{-1}$ e $142 \mathrm{mS} . \mathrm{cm}^{-1}$ (65 으, $\mathrm{RH}=100 \%$ ), respectivamente. Este comportamento foi influenciado pelas características dos polímeros 
(massa molar, cristalinidade), a dose de radiação e o tempo de armazenamento a baixa temperatura (formação, estabilidade e reações de recombinação). Os resultados sugerem que as membranas de LDPE e UHMWPE são eletrólitos promissores para aplicação em célula a combustível alcalina.

Polímero semi-fluorado - filmes de poli(etileno-co-tetrafluoroetileno (PETFE). O processo de pré-irradiação por feixe de elétrons na dose de 70 kGy, armazenamento a baixa temperatura $(-70 \pm 4 \stackrel{\circ}{\circ})$ e solução de estireno:propano-2-ol na relação $60: 40 \mathrm{v}: \mathrm{v}$, foi adequado à obtenção de membranas de condutividade iônica (forma $\mathrm{OH}^{-}$) obtendo-se valores de 90 a $165 \mathrm{mS} \mathrm{cm}^{-1}$ entre 30 e $60 \stackrel{\circ}{\circ} \mathrm{em} \mathrm{RH}=100 \%$ valores próximos ao Nafion ${ }^{\mathrm{TM}}$ 115 , indicando a possibilidade de aplicação em células a combustível alcalinas. Os radicais gerados na irradiação foram preservados por até 10 meses quando mantidos a temperatura baixa $(-70 \stackrel{\circ}{\circ})$, sendo dois meses o tempo mínimo de estabilização.

Polímero totalmente fluorado - poli(tetrafluoroetileno-co-hexafluoroetileno) (PFEP). Os filmes de PFEP foram influenciados pelas características de resistência a irradiação do polímero, método e dose de radiação. O processo simultâneo de irradiação a baixas doses de radiação, usando a solução de propano-2-ol, favoreceu a homogeneidade da enxertia, porém em nível insuficiente para a síntese das membranas. 


\section{TRABALHOS FUTUROS}

Com base nos resultados e conclusões deste trabalho, sugere-se que sejam realizados estudos adicionais destacados a seguir:

Realizar teste em célula a combustível alcalina.

Avaliar monômeros alternativos para a substituição do monômero utilizado neste trabalho, como por exemplo, o cloreto de vinil benzeno (VBC).

Avaliar aminas mais estável,como por exemplo, DABCO.

Avaliar a influência dos parâmetros dose absorvida de radiação, e solução de enxertia (concentração e tipo de monômero em diferentes soluções de solventes buscando reagentes de menor toxidez) no desempenho e estabilidade da célula a combustível alcalina.

Realizar testes com os polímeros polietileno de baixa densidade (LDPE), polietileno de ultra alto peso molecular (UHMWPE), utilizando doses absorvidas de radiação menores e taxas de dose mais altas, e com menores tempos de armazenamento a baixas temperaturas $(70 \pm 4 \stackrel{\circ}{ } \mathrm{C})$.

Realizar testes com o polímero poli(tetrafluoroetileno-co-hexafluoroetileno) (PFEP) em doses absorvidas de radiação mais baixas 


\section{REFERÊNCIAS BIBLIOGRÁFICAS}

ALBANO, C.; PERERA, R.; SILVA, P.; SANCHEZ, Y.Characterization of gamma irradiated PEs using ESR, FTIR and DSC tecniques. Polymer Bulletin, v. 51, p. 135-142, 2003.

BOKNAM, C.; Y. M.; DO-HUNG, H.; KIM, S. B.; LEE, S. W. Spectroscopy and thermal degradation studies of polystyrene grafting onto poly(tetrafluoroethylene-co-hexafluoropropylene) films via electron-beam irradiation. Vibrational Spectroscopy, v. 51, n. 1, p. 72-75, 2009.

BONNELL, D., Scanning Probe Microscopy and Spectroscopy: Theory, Techniques, and Applications, Wiley-VCH, USA, 1993.

BRADLEY, R. Radiation Technology Handbook. [S.I.]: Marchel Dekker, 1984. BROUZGOU, A.; PODIAS, A.; TSIAKARAS, P. PEMFCs and AEMFCs directely fed with ethanol: a current status comparative review. Journal of AppliedElectrochemistry, v. 43, p. 119-136, 2013.

BRUSTOLON, M.; GIAMELLO, E. Electron Paramagnetic Resonance. New Jersey: John Wiley \& Sons, 2009.

BUtTAfava, A., taVARES, A., ARIMONDI, M., ZAOPO, A., NESTI, S., DONDI, D., MARIANI, M., FAUCITANO, A. Dose rate effects on the radiation induced oxidation of polyethylene. Nuclear Instruments and Methods in Physics research, v. 265, p. 221-226, 2007.

CAO, Y. C.; SCOTT, K.; WANG, X. Preparation of polytetrafluoroethylene porous membrane based composite alkaline membrane with improved tensile strenght and its fuel cell test. International Journal of Hydrogen Energy, v. 37, p. 12688-12693, 2012.

CHENG, J.; HE, G.; ZHANG, F. A mini-review on anion exchange membranes for fuel cell applications: stability issue and adressing strategies. International Journal of Hydrogen Energy, v. 40, p. 7348-7360, 2015. 
COUTINHO, F. M. B.; MELLO, I. L.; MARIA SANTA, L. C. Polietileno: principais tipos, propriedades e aplicações. Polímeros Ciência e Tecnologia, v. 13, p. 1-13, 2003.

COUTURe, G.; Allaeddine, A.; BOSCHet, F.; AMEduRI, B. Polymeric materials as anion exchange membranes for alkaline fuel cells. Progress in Polymer Science, v. 36, p. 1521-1537, 2011.

DARGAVILLE, T. R.; GEORGE, G. A.; HILL, D. J. T.; WHITTAKER, A. K. High energy radiation grafting of fluoropolymers. Progress in Polymer Science, v. 28, p. 1355-1376, 2003.

DOLE, M. The radiation Chemistry of Macromolecules. New York : Academic Press, v. I, 1972.

DENARO, A. R.; JAYSON, G. G. Fundamentals of radiation Chemistry. London : Butterworks, 1972.

ESPIRITU, R., MAMLOUK, M., SCOTT, K., Study of the effect of the degree of grafting on the performance of polyethylene-based anion exchange membrane for fuel cell application. International Journal of Hydrogen Energy, v. 41,p. 1120-1133, 2016.

ESPIRITU, R.; GOLDING, B. T.; SCOTT, K.; MAMLOUK, M. Degradation of radiation grafted hydroxide anion exchange membrane immersed in neutral $\mathrm{pH}$ : removal of vinylbenzyl trimethylammonium. Journal of Materials Chemistry, v. 5 , p. 1248-1267, 2017.

FANG, J.; YANG, Y.; LU, X.; YE, M.; ZHANG, Y.Cross-linked, ETFE-derived and radiation grafted membranes for anion exchange membrane fuel cell applications. International Journal of Hydrogen Energy, v. 37, p. 594-602, 2012.

FEL, E.; KHROUZ, L.; MASSARDIER, V.; BONNEVIOT, L. Comparative study of gamma- irradiated $\mathrm{PP}$ and $\mathrm{PE}$ polyolefins part $\mathrm{I}$ : Identification and quantification of radicals using electron paramagnétic resonance. Polymer, v. 77, p. 278-288, 2015. 
FURUKAWA, T., SATO, H., KITA, Y., MATSUKAWA, K., YAMAGUCHI, H., OCHIAI, S., SIESLER, H. W., OZAKI, Y. Molecular structure, crystallinity and morphology of polyethylene/propylene blends studied by RAMAN mapping, scanning electron microscopy, wide sigle $x$-ray diffraction, and differential scanning calorimetry. Polymer Journal, v. 38, p. 1127-1136, 2006.

GONZALEZ, J. P.; WHELLIGAN, D. K.; WANG, L.; SOUALHI, R. B.; WANG, Y.; PENG, Y.; PENG, H.; APPERLEY, D. C.; SARODE, H. N.; PANDEY, T. P.; DIVEKAR, A. G.; SEIFERT, S.; HERRING, A. M.; ZHUANG, L.; VARCOE, J. R. High performance aliphatic-heterocyclic benzyl-quaternary ammonium radiation-grafted anion-exchange membranes. Energy Environmental Science, v. 9, p. 3724-3734, 2016.

GUILMEAU, I., ESNOUF, S.,BETZ, N., MOEL, A L., Kinetics and characterization of radiation-induced grafting of styrene on fluoropolymers, Nuclear Instruments and Methods in Physics Research, v. 131, p. 270-275, 1997.

GLUBER L., GURSEL, S. A., SCHERER, G. G. Radiation grafted membrane for polymer electrolyte fuel cells. Fuel Cells, v. 5, p. 317- 335, 2005.

GUBLER, L. Polymer Design Strategies for Radiation-Grafted Fuel Cell Membranes. Advanced Energy Materials, v. 4, p.1-30, 2014.

GUPTA, B.; SCHERER, G. Proton exchange membranes by radiation-induced graft copolymerization of monomers into Teflon-PE films. Chimia, v. 48, p. 127137, 1994.

HAMADA, Y.; NAKAMURA, M.; KUBOTA, H.; OCHIFUJI, K.; MURASE, M.; GOTO, R.Field performance of a polymer electrolyte fuel cell for a residential energy system. Renewable and Sustainability Energy Reviews, v. 9, p. 345362, 2004. 
HERMAN, H.; SLADE, R. C. T.; VARCOE, J. R. The radiation-grafting of vinylbenzyl chloride onto poly(hexafluoropropylene-co-tetrafluoroethylene) films with subsequent convertion to alkaline anion-exchange membranes: optimization of the experimental conditions and characterization. Journal of Membrane Science, v. 218, p. 147-163, 2003.

JEONG, S. K.; LEE, J. S.; WOO, S. H.; SEO, J. A.; MIN, B. R. Characterization of anion exchange membrane containing epoxy ring and $\mathrm{C}-\mathrm{Cl}$ bond quaternized by various amine groups for application in fuel cells. Energies, v. 8, n. 7, p. 7084-7099, 2015.

KIZEWSKI, J. P.; MUDRI, N. H.; VARCOE, J. R. An empirical study into the effect of long term storage $(-36+/-2 \stackrel{\circ}{\circ})$ of electron-beamed ETFE on the properties of radiation-grafted alkaline anion-exchange membranes. RadiationPhysics and Chemistry, v. 89, p. 64-69, 2013.

KO, B. S., SOHN, J. Y., SHIN, J. Radiation-induced synthesis of alkaline exchange membranes with quaternized 1,4-diazobicyclo[2,2,2] octane pendant groups for fuel cell applications. Polymer, v. 53, p. 4652-4661, 2012.

KORDESCH, K.; CIFRAIN, M. Fuel Cells Handbook. Morgantown, West Virginia: EG\&G Techinical Services, 2004.

KORDESCH, K.; SIMADER, G. Fuel Cells and Their Applications. New York (USA): VCH Publishers, 1996.

LAPPAN, U.; GEIBLER, U.; GOHS, U.; UHLMANN, S. Influence of irradiation temperature on grafting of styrene into poly(tetrafluoroethylene-cohexafluoropropylene) films. Macromolecular Materials andEngeneering, v. 294, p. 510-515, 2009.

LARMINIE, J.; DICKS, A. Fuel Cell Systems Explained. 2nd ed.New York:John Wiley \& Sons, 2003.

LARSEN, M. J.; MA, Y.; QIAN, H.; TOFTLUND, H.; LUND, P. B.; SKOU, E. M.Stability of radicals in electron-irradiated fluoropolymer film for the preparation of graft copolymer fuel cell electrolyte membranes. Solid State Ionics, v. 181, n. 3-4, p. 201-205, 2010. 
LI, Y. S.; ZAO, T. S.; YANG, W. W. Measurements of water uptake and transport properties in anion-exchange membranes. International Journal of Hydrogen Energy, v. 35, p. 5656 - 5665, 2010.

LINARDI, M. Introdução à Ciência e Tecnologia de Células a Combustível. São Paulo: Artliber , 2010.

LIU, H., YANG, S.; WANG, S.; FANG, J.; JIANG, L.; SU, G. Preparation and characterization of radiation-grafted poly (tetrafluoroethylene-co-perfluoropropyl vinyl ether) mmebranes for alkaline anion-exchange membrane fuel cells. Journal of membrane Science, v. 369, p. 277-283, 2011.

LUCON, O.; ROMEIRO, V.; FRASEN,F. Oportunidades e desafios para aumentar sinergias entre políticas climáticas e energéticas no Brasil. WRI Brasil. Disponível em: <http://wribrasil.org.br/pt/publication>. Acesso em: 20 fev. 2017.

MANLOUK, M.; HORSFALL, J. A.; WILLIAMS, C.; SCOTT, K. Radiation grafted membranes for superior anion exchange polymer membrane fuel cells performance. International Journal of HydrogenEnergy, v. 37, p. 1191211920, 2012.

MANLOUK, M.; SCOTT, K. Effect of anion functional groups on the conductivity and performance of anion exchange polymer membrane fuel cells. Journal of Power Sources, v. 211, p. 140-146, 2012.

MAURITZ, R. A., MOORE, R. B. State of understanding of Nafion. Chemical review, v. 104, p. 4535-4585, 2004.

MAURYA, S.; SHIN, S. H., KIM, M. K.; YUN, S. H., MOON, S. H. Stability of composite anion exchange membranes with various functional groups and their performance for energy convertion. Journal of Membrane Science, v. 443, p. 28-35, 2013.

MAURYA, S.; SHIN, S. H.; KIM, Y.; MOON, S. H. A review on recent developments of anion exchange membranes for fuel cells and redox flow batteries. RSC Advances, v. 5, p. 37206 - 37230, 2015. 
MERLE, G.; WESSLING, M.; NUMEIJER, K.Anion exchange membranes for alkaline fuel cells: A review. Journal of Membrane Science, v. 377, p. 1-35, 2011.

MEYER, E.; HUG, H. J.; BENNEWITZ, R. Scanning Probe Microscop : The Lab on a Tip: Springer-Verlag, New Yok, 1965.

MITOV, S.; HUBNER, G.; BRACK, H.; SCHERER, G. G.; RODUNER, E. In sito Electron Spin Resonance Study of Styrene Grafting of Electron Irradiated Fluoropolymer Films for Fuel Cell membranes. Journal of Polymer Science: Part B, Polymer Physics, v. 44, p. 3323-3326, 2006.

NASEF, M. M.; HEGAZY, E. A. Preparation and applications of ion exchange membranes by radiation-induced graft copolymerization of polar monomers onto polar flms. Progress Polymer Science, v. 29, p. 499-634, 2004.

NASEF, M. M.; ROHANI, R., HAMDANI, S.; KHAIRUL, Z. M. D. Effect of liquid additives on graft copolymerization of styrene onto preirradiated poly(ethyleneco-tetrafluoroethylene) films. International Journal of Applied Chemistry, v. 4, p. 187-203, 2008.

OLIVEIRA, L. Honda Clarity e Toyota Mirai disparam na "corrida" do carro a hidrogênio. Disponível em: <http://g1.globo.com/carros/noticia/2015/10/hondaclarity-e-toyota-mirai-disparam-na-corrida-do-carro-hidrogenio.html>Acesso em: 14 fev. 2017

PITTERGER, B. Atomic Imaging with Peak Force Tapping. BRUKER. Disponível em: <lmaginghttps://www.bruker.com/fileadmin/user_upload/8-PDFDocs/SurfaceAnalysis/AFM/Webinars/Atomic_Imaging_with_Peak_Force_Tappi ng_slides_20120613.pdf $>$ Acesso em: 20 fev. 2017.

POYNTON, S. D.; SLADE, R. C. T.; OMASTA, T. J.; TRAVIS, J.; MUSTAIN, W. E.; ESCUDERO-CID,R.; OCON, P.; VARCOE, J. R. Preparation of radiationgrafted powders for use as anion-exchange ionomers in alkaline polymer electrolyte fuel cells. Journal of Materials Chemstry A: Materials for Energy and Sustainability, v. 2, n.14, p. 5124-5130, 2014. 
POYNTON, S. D.; VARCOE, J. R. Reduction of the monomer quantities required for the preparation of radiation-grafted alkaline anion-exchange membranes. Soild State lonics, v. 277, p. 38-43, 2015.

RAGER, T. Pre-Irradiation grafting os styrene/Divinylbenzene onto Poly(tetrafluoroethylene-co-hexafluoropropylene) from Non-Solvents. Helvetica Chimica Acta, v. 86, p. 1966-1981, 2003.

RAN, J.; WU, L.; HE, Y.; YANG, Z.; WANG, Y.; JIANG, C.; GE, L.; BAKANGURA, E.; XU, T.lon Exchange membranes: New developments and aplication. Journal of Membrane Science, v. 522, p. 267-291, 2017.

ROHANI, R.; NASEF, M. M.; SAIDI, H.; DAHLAN, K. Z. M. Effect of reaction conditions on electron induced graft copolymerization of styrene onto poly(ethylene-co-tetrafluoroethylene) films: Kinetics study. Chemical Engineering Journal, v. 132, p. 27-35, 2007.

SARAH, L.; VARCOE, J. R.; SLADE, R. C. T. Examination of AmineFunctionalised Anion-Exchange Membranes for Possible Use in the AllVanadium Redox Flow Battery. Electrochimica Acta, v. 140, p. 145-151, 2014.

SATEER, G. Fuel Cells going on board. Journal of Power Sources, v. 86, p. 61-67, 2000.

SHERAZI, T. A.; SOHN, J. Y.; LEE, Y. M.; GUIVER, M. D. Polyethylene-based radiation graft anion-exchange membranes for alkaline fuel cells. Journal of Membrane Science, v. 441, p. 148-157, 2013.

SHERAZI, T. A.; AHMAD, S.; KASHMIRI, M.A.; GUIVER, M. D.Radiationinduced grafting of styrene onto ultra-high-molecular weight polyethylene powder and subsequent film fabrication for application as polymer electrolyte membranes: I. Influence of grafting conditions. Journal of Membrane Science, v. 325, n. 2, p. 964-972, 2008. 
SHERAZI, T. A.; AHMAD, S.; KASHMIRI, M. A.; KIM, D. S.; GUIVER, M. D. Radiation-induced grafting of styrene onto ultra-high-molecular weight polyethylene powder for polymer electrolyte fuel cell application II. Sulfonation and characterization, Journal of Membrane Science,v. 333, p. 59-67, 2009.

SLADE, R. C. T.; VARCOE, J. R. Investigations of conductivity in FEP-based radiation-grafted alkaline anion-exchange membranes. Solid States Ionics, v. 176, p. 585-597, 2005.

SPINKS, J. W. T.; WOODS, R. J. An Introduction to Radiation Chemistry. 3rd ed. New York:John Wiley \& Sons, 1990.

TABATA, Y. Radiochemistry Handbooks. Manual. [S.I.]: [s.n.], 1928.

TICIANELLI, E. A., GONZALEZ, E. R. Eletroquímica: Princípios e Aplicações. 2nd. ed. São Paulo. Editora da Universidade de São Paulo, 2013.

VARCOE, J. R. Investigation of the ex situ ionic conductivities at $30^{\circ} \mathrm{C}$ of metalcation-free quaternary ammonium alkaline-anion exchange membranes in static atmospheres of diferent relative humidities. Physical Chemistry Chemical Physics, v. 9, p. 1479-1486, 2007.

VARCOE, J. R.; ATANASSOV, P.;DEKEL, D. R.;HERRING, A. M.;HICKNER, M. A.;KOHL, P. A.;KUCERNAK, A. R.;MUSTAIN, W. E.;NIJMEIJER, K.;SCOTT, $\mathrm{K}$;:XU, T.; ZHUANG, L. Anion-exchange membranes in electrochemical energy systems. Energy Environmental Science, v. 7, n. 10, p. 3135-3191, 2014.

VARCOE, J. R.; SLADE, R. C. T. An electron-beam-grafted ETFE alkaline anion-exchange membranes in metal-cation-free solid-state alkaline fuel cells. Electrochemistry Communications, v. 8, p. 839-843, 2006.

VARCOE, J. R.; SLADE, R. C. T.; YEE, E. L. H.; POYTON, S. D.; DRISCOLL, D. J.; APPERLEY, D. C. Poly(ethylene-co-tettrafluoroethylene) derived radiation-grafted anion exchange membrane with properties specifically tailored for application in metal-cation-free alkaline polymer electrolyte fuel cells. Chemical Matter, v. 19, p. 2686-2693, 2007 
VIELSTICH, W., LAMM, A., GASTEIGER, H. A. Handbook of Fuel Cells. John Willy and Sons Ltd. London, 2003. v. 4: Fundamentals Technology and Applications.

WALSBY, N.; SUNDHOLM, F.; KALLIO, T.; SUNDHOLM, G. Radiation-Grafted Ion-Exchange Membranes: Influence of the Initial Matrix on the Synthesis and Structure. Journal of Polymer Science Part A: Polymer Chemistry, v. 39, n. 1717 , p. 3008-3017, 2001.

WANG, X.; JOSUA, P. M.; FEDKIW, P. S. Transport properties of proton-and hydroxide-exchange membranes. Electrochemica Acta, v. 79, p. 126-132, 2012.

WANG, Y. J.; QIAO, J.; BAKER, R.; ZHANG, J. Alkaline polymer electrolyte membranes for fuel cell applications. Chemical Society Reviews, v. 47, p. 5768-5787, 2013.

WANG, L.; MAGLIOCCA, E.; CUNNINGHAM, E.; MUSAIN, W.; POYTON, S. D.; CID, E. R.; NASEF, M. M.; GONÇALEZ, J. P.; SOUAHLI, R. B.; SLADE, R. C.T,; WHELLIGAN, D. K.; VARCOE, J. R. An optimised synthesis of high performance radiation-grafted anion-exchange membranes. Green Chemistry, v. 19, p. 831-843, 2017.

WEIL, J. A.; BOLTON, J. R. Electron Paramagnetic Resonance: Elementary Theory and Practical Application. 2nd ed. New Jersey: John Willey and Sons, Hoboken, 2007.

WOODS, R. J.; PIKAEV, A. K. Applied Radiation Chemistry: Radiation Processing. New York: John Willey \& Sons, 1994.

$\mathrm{XU}, \mathrm{T}$. Ion exchange membranes: State of their development and perspective. Journal of Membrane Science, v. 263, p. 1-29, 2005.

YAMAMOTO, M.; TOI, K. Polymeric materials as anion exchange membranes for alkaline fuel cells. Progress in Polymer Science, v. 36, n. 11, p. 15211557, 2011. 
ZHOU, T.; SHAO, R.; CHEN, S.; HE, X.; QIAO, J.; ZHANG, J. A review of radiation-grafted polymer electrolyte membranes for alkaline polymer electrolyte membrane fuel cells. Journal of Power Sources, v. 293, p. 946-975, 2015. 